\title{
Environmental Control Technology Activities of the Department of Energy in FY 1977
}

November 1977 


\section{DISCLAIMER}

This report was prepared as an account of work sponsored by an agency of the United States Government. Neither the United States Government nor any agency Thereof, nor any of their employees, makes any warranty, express or implied, or assumes any legal liability or responsibility for the accuracy, completeness, or usefulness of any information, apparatus, product, or process disclosed, or represents that its use would not infringe privately owned rights. Reference herein to any specific commercial product, process, or service by trade name, trademark, manufacturer, or otherwise does not necessarily constitute or imply its endorsement, recommendation, or favoring by the United States Government or any agency thereof. The views and opinions of authors expressed herein do not necessarily state or reflect those of the United States Government or any agency thereof. 


\section{DISCLAIMER}

Portions of this document may be illegible in electronic image products. Images are produced from the best available original document. 


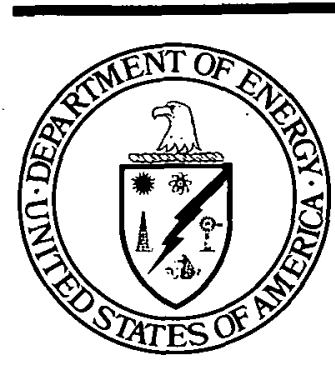

\section{Environmental Control Technology Activities of the Department of Energy in FY 1977}

November 1977

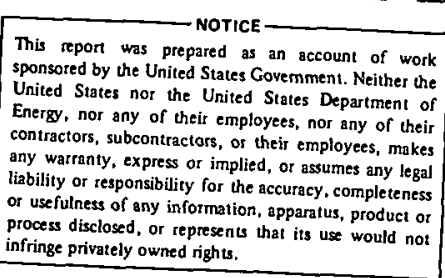

U.S. Department of Energy Division of Environmental Control Technology Washington, DC 20545 


\section{NOTICE}

This report was prepared as an account of work sponsored by the United States Government. Neither the United States nor the United States Department of Energy, nor any of their employees, nor any of their contractors, subcontractors, or their employees, makes any warranty, express or implied, or assumes any legal liability or responsibility for the accuracy, completeness or usefulness of any information, apparatus, product or process disclosed, or represents that its use would not infringe privately owned rights.

Avatlable from:

National Technical Information Service (NTIS)

U.S. Department of Commerce

5285 Port Royal Road

Springfield, Virginia 22161

Price: $\quad$ Printed Copy: $\quad \$ 6.00$

Microfiche: $\$ 3.00$ 


\section{PREFACE}

This inventory covers environmental control related activities carried out during Fiscal Year (FY) 1977 by the Energy Research and Development Administration (ERDA). For clarity, no attempt has been made within the body of the report to translate ERDA organizational terminology to that of the Department of Energy (DOE). The FY 1978 edition will survey all the DOE energy technology projects. 
TABLE OF CONTENTS

Page

Number

\section{PREFACE}

I. BACKGROUND 1

II. PURPOSE 2

III. SUMMARY 3

IV. RESULTS 22

A. Conservation 24

B. Fossil Energy . 33

C. Nuclear Energy 48

D. Solar, Geothermal and Advanced
Energy Systems

E. Environment and Safety 66

$\begin{array}{ll}\text { V. BIBLIOGRAPHY } & 77\end{array}$

$\begin{array}{ll}\text { VI. GLOSSARY } & 78\end{array}$ 


\section{LIST OF FIGURES}

Figure

Page

Number

III-1 Distribution of Total ERDA Environmental Control Activities Related to FY 1977 Funding by Administration

6

7 Related to FY 1977 Funding by Energy Category

III-3 Distribution of Environmental Control Technology Funding in the Office of the Assistant Administrator for Conservation

in the Office of the Assistant Administrator for Fossil Energy

Administrator for Fossil Energy

in the Office of the Assistant Administrator for Nuclear Energy

in the Office of the Assistant Administrato
Geothermal, and Advanced Energy Systems

III-8 Distribution of Environmental Control Technology Funding in the Office of the Assistant Administrator for

Environment and Safety

III-9 Distribution of Environmental Control Technology Funding by Energy Category in the Office of the Assistant

Administrator for Environment and Safety 


\section{LIST OF TABLES}

$\underline{\text { Table }}$

Page

Number

III-1 Total ERDA Environmental Control Activities

Funding Allocations

III-2 Conservation Environmental Control Activities

Related Funding

III-3 Fossil Energy Environmental Control Activities

Related Funding

III-4 Coal Program Environmental Control Activities

Related Funding

III-5 Nuclear Energy Environmental Control Activities

Related Funding

III-6 Solar, Geothermal, and Advanced Energy Systems

Environmental Control Activities Related Funding

III-7 Environment and Safety Environmental Control

Activities Related Funding

III-8 Environment and Safety Breakdown of FY 1977

Funding Related to Environmental Control Activities

IV-1 Criteria for Applicability to Environmental Control Technology

IV-2 Projects with Environmental Control Aspects;

Conservation; Building and Community Systems

IV-3 Projects with Environmental Control Aspects;

Conservation; Conservation Research and

Technology

IV-4 Projects with Environmental Control Aspects;

Conservation; Electric Energy Systems

IV-5 Projects with Environmental Control Aspects;

Conservation; Energy Storage Systems

IV-6 Projects with Environmental Control Aspects;

Conservation; Industrial Energy Conservation

IV-7 Projects with Environmental Control Aspects;

Conservation; Transportation Energy Conservation 
IV-8 Projects with Environmental Control Aspects;

Fossil Energy; Coal; Liquefaction

IV-9 Projects with Environmental Control Aspects; Fossil Enèrgy; Coal; High-Bru Gasification

IV-10 Projects with Environmental Control Aspects; Fossil Energy; Coal; Low-Btu Gasification

IV-11 Projects with Environmental Control Aspects; Fossil Energy; Coal; Advanced Power Systems

IV-12 Projects with Environmental Control Aspects; Fossil Energy; Coal; Direct Combustion

IV-13 Projects with Environmental Control Aspects; Fossil Energy; Coal; Advanced Research and Support Technology

IV-14 Projects with Environmental Control Aspects; Fossil Energy; Coal; Demonstration Plants

IV-15 Projects with Environmental Control Aspects; Fossil Energy; Coal; Magnetohydrodynamics

IV-16 Projects with Environmental Control Aspects; Fossil Energy; Petroleum and Natural Gas; Enhanced Oil Recovery

IV-17 Projects with Environmental Control Aspects; Fossil Energy; Petroleum and Natural Gas; Enhanced Gas Recovery

VI-18 Projects with Environmental Control Aspects; Fossil Energy; Petroleum and Natural Gas; Drilling, Exploration, and Offshore Technology

IV-19 Projects with Environmental Control Aspects; Fossil Energy, Petroleum and Natural Gas; Processing and Utilization

IV-20 Projects with Environmental Control Aspects; · Fossil Energy; Oil Shale and In Situ Technology; Oil Shale

IV-21 Projects with Environmental Control Aspects;

Fossil Energy; Oil Shale and In Situ

Technology; In Situ Coal Gasification

IV-22 Projects with Environmental Control Aspects; Nuclear Energy; Nuclear Research and Applications 
IV-23 Projects with Environmental Control Aspects; Nuclear Energy; Reactor Development and Demonstration

IV-24 Projects with Environmental Control Aspects; Nuclear Energy; Waste Management, Production, and Reprocessing-Commercial Waste Program

IV-25 Projects with Environmental Control Aspects; Solar, Geothermal, and Advanced Energy Systems; Geothermal Energy

IV-26 Projects with Environmental Control Aspects; Solar, Geothermal, and Advanced Energy

Systems; Magnetic Fusion Energy

IV-27 Projects wtih Environmental Control Aspects; Solar, Geothermal, and Advanced Energy Systems; Physical Research

IV-28 Projects with Environmental Control Aspects; Solar, Geothermal, and Advanced Energy Systems; Solar Energy

IV-29 Projects with Environmental Control Aspects; Environmental and Safety; Biomedical and Environmental Research

IV-30 Projects wtih Environmental Control Aspects; Environmental and Safety; Environmental Control Technology 


\section{Background}

The Department of Energy (DOE) is responsible for the Research, Development, and Demonstration (RD\&D) of emerging energy technologies and the promotion of energy conservation. An integral and significant part of that responsibility includes the balancing of energy goals with environmental requirements to protect and enhance the general health, safety, and welfare of the nation. This requires that environmental effects be considered and mitigating measures by taken in all energy processes through incorporation of environmental and safety controls which are developed as an integral part of energy system design.

The Division of Environmental Control Technology (ECT) within the office of the Assistant Secretary for Environment (ASEV) is responsible for ensuring, through overview and independent assessment, the timely development of adequate environmental control technology capability with DOE's energy technology RD\&D programs. The projects directly under the cognizance of ECT are primarily independent overview and assessments designed to provide this assurance or to establish the Research and Development (R\&D) requirements for environmental controls. The energy technology offices have the direct responsibility for conduct of RD\&D of environmental controls in conjunction and in phase with their respective energy technology $R D \& D$ programs to assure environmental acceptability of the energy technology at commercialization.

This inventory of environmental control technology activities was initiated by the Administrator, ERDA, prior to the incorporation of that administration within the Department of Energy. This compilation of total Energy Research and Development Administration (ERDA) environmental control technology activities, and associated funding, related to environmental control technology identifies the resources committed by ERDA to demonstrate its objective to protect and enhance the general health, safety, and welfare of the nation in the Research, Development, and Demonstration of energy systems. Again, it should be stressed that only ERDA research, development, and demonstration activities are covered in this report. The compilation for FY 1978 will encompass all of the DOE activities. 


\section{Purpose}

The primary purpose of this first in a series of annual reports is to identify and catalog the DOE's environmental control activities conducted in support of developing environmentally acceptable energy technologies. Since environmental control technology is an integral part of the DOE energy technology RD\&D effort, the total program activity in this area is not clearly identifiable. This inventory provides visibility into the total DOE environmental control activity for use by councils of government, other agencies, and the private sector. It is useful to distinguish explicitly actual DOE efforts in this area so as to provide a basis for establishment of future needs and requirements. This report will provide an initial reference source to be used for future environmental control planning within the DOE and to serve as a reference base from which related activities outside of the DOE may be evaluated and compared.

As the first in a series of annual reports on environmental control technology activities within the DOE, this report will serve as a basis for evaluating progress in the development of environmental controls. As a baseline comparison datum, it will provide the background material required to evaluate and assess the environmental control accomplishments, issues, gaps, and overlaps associated with energy development within the DOE, in conjunction with other agencies, and in the private sector. 


\section{Summary}

The total ERDA FY 1977 funding allocation related to environmental control activities, as shown in Table III-1, was $\$ 184,683,000$. This corresponds to approximately 3\% of the Total FY 1977 ERDA budget. The distribution of this $\$ 184,683,000$ by each office is depicted in Figure III-1. Detail project listings are provided in Section IV. The office of the Assistant Administrator for Fossil Energy (AFE) and the office of the Assistant Administrator for Nuclear Energy (ANE) together accounted for $80 \%$ of the total ERDA FY 1977 funding allocation related to environmental control technology.

The distribution by energy technology category is depicted in Figure III-2. The coal program was almost half ( 48 percent) of the total, followed by nuclear with 38 percent, of which 30 percent was related to waste management, production, and reprocessing. Geothermal comprised 5 percent and conservation 3 percent while the remaining categories were each 2 percent or less of the total FY 1977 funding related to environmental control technology. Tables III-2 through III-8 present further details for the office of the Assistant Administrator for Conservation (AC), AFE, ANE, the office of the Assistant Administrator for Solar, Geothermal, and Advanced Energy Systems (ASGA), and the office of the Assistant Administrator for Environment and Safety (AES).

Table III-2 presents the funding breakdown for Conservation. As shown in Figure III-3, 46 percent of the funding was in the Division of Electric Energy Systems. This work is mainly directed at electric field effects of direct current lines, research in the biological effects of high voltage electric fields, and animal studies regarding transmission line effects.

Fossil Energy funding allocations are shown in Table III-3 with breakdowns for Coal, Oil Shale and In-Situ Technology, and Petroleum and Natural Gas. The associated distribution of funding, within these three programs, is depicted in Figure III-4. Since the Coal program comprises the majority (95 percent) of the AFE funding associated with environmental control activities, Table III-4 and Figure III-5 are presented to show the distribution within the coal program. More than half ( 62 percent) of the coal program environmental control activities were supported by direct combustion and liquefaction programs. The remaining 38 percent is associated with gasification projects (20 percent), demonstration plants ( 7 percent), and advanced coal technology (11 percent) of the coal program within Fossil Energy.

Nuclear Energy summary funding data is presented in Table III-5. As shown therein and in Figure III-6, the major portion of the ANE funding related to environmental control activities was in the area of commercial waste management of which 90 percent is estimated to be allocated.

Associated funding breakdowns and corresponding distributions for the Solar, Geothermal, and Advanced Energy Administration (ASGA) are depicted in Table III6 and Figure III-7, respectively. Geothermal energy comprised 71 percent of the total FY 1977 funding related to environmetnal control technology within ASGA. The majority was in $\mathrm{H}_{2} \mathrm{~S}$ control, subsidence control, drilling technology, resource exploration and assessment, and hydrothermal technology applications. Solar energy activities in the environmental control technology area comprised 22 percent with advanced ASGA projects in the divisions of physical research and magnetic fusion making up the remaining 7 percent. 
The office of the Assistant Administrator for Environment and Safety (AES) FY 1977 funding breakdown related to environmental control activities is shown in Table III-7 by divisional structure. The total was $\$ 17,973,000$ of which the Division of Environmental Control Technology was responsible for 93 percent as shown in Figure III-8. The AES distribution within the main energy related sub-programs is shown in Table III-8 and depicted in Figure III-9. Within AES, nuclear related projects accounted for almost half ( 45 percent) with fossil energy related projects accounting for 33 percent of the environmental control related activities. The remainder was divided up into solar, geothermal, and advanced energy systems, conservation, and multi-technology which included the ECT efforts in the area of energy materials transportation. The distribution of environmental control related projects is shown in Figure III-9 with the management of surplus facilities and fossil projects accounting for the majority. 
TABLE III- 1

TOTAL DOE ENVIRONMENTAL CONTROL ACTIVITIES FUNDING ALLOCATIONS

\begin{tabular}{|l|c|c|}
\hline & $\begin{array}{c}\text { FY 1977 Funding Allocation } \\
\text { Related to Environmental } \\
\text { Control Activities }\end{array}$ & $\begin{array}{c}\text { Portion of Total FY 1977 } \\
\text { Budget Related tc } \\
\text { Environmental Cont.rol } \\
\text { Activities } \\
\text { (Percent)* }\end{array}$ \\
\hline $\begin{array}{l}\text { Conservation (AC) } \\
\text { Fos sil Energy (AFE) }\end{array}$ & 5,984 & 4.8 \\
Nuclear Energy (ANE) & 86,194 & 19.4 \\
Solar, Geothermal, and Advanced \\
Energy Systems (ASGA) \\
Environment and Safety (AES)
\end{tabular}

TOTAL DOE FY 1977 Budget: $\$ 5,383,982,000$

* To nearest tenth of a percent

** National Security (ANS) excluded - See Section IV 
TOTAL ERDA FY 1977 FUNDING

RELATED TO ENVIRONMENTAL CONTROL: $\$ 184,683,000$

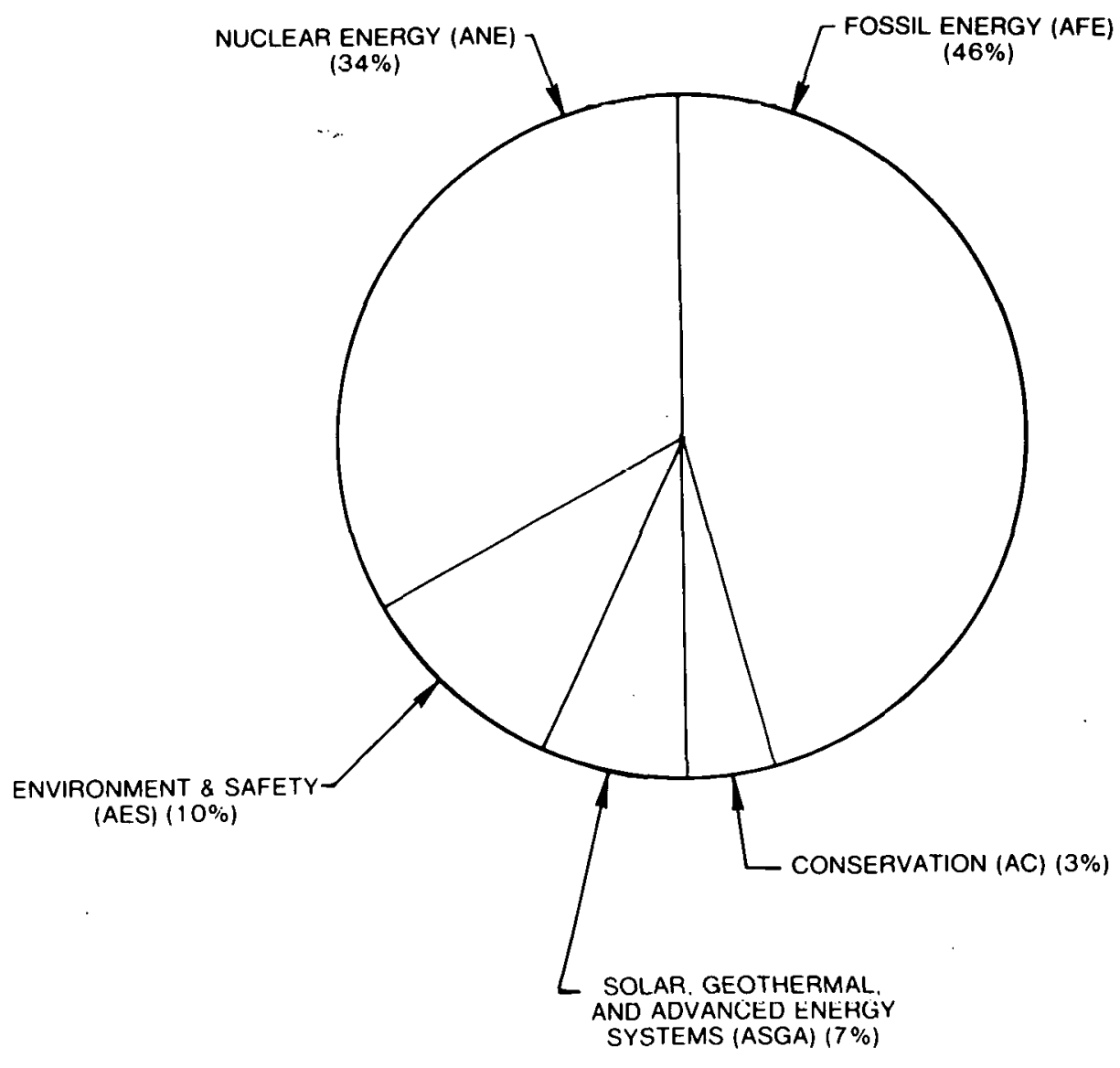

FIGURE IIF-1 Distribution of Total ERDA Environmental Control Activities Related to FY 1977 Funding by Administration. 


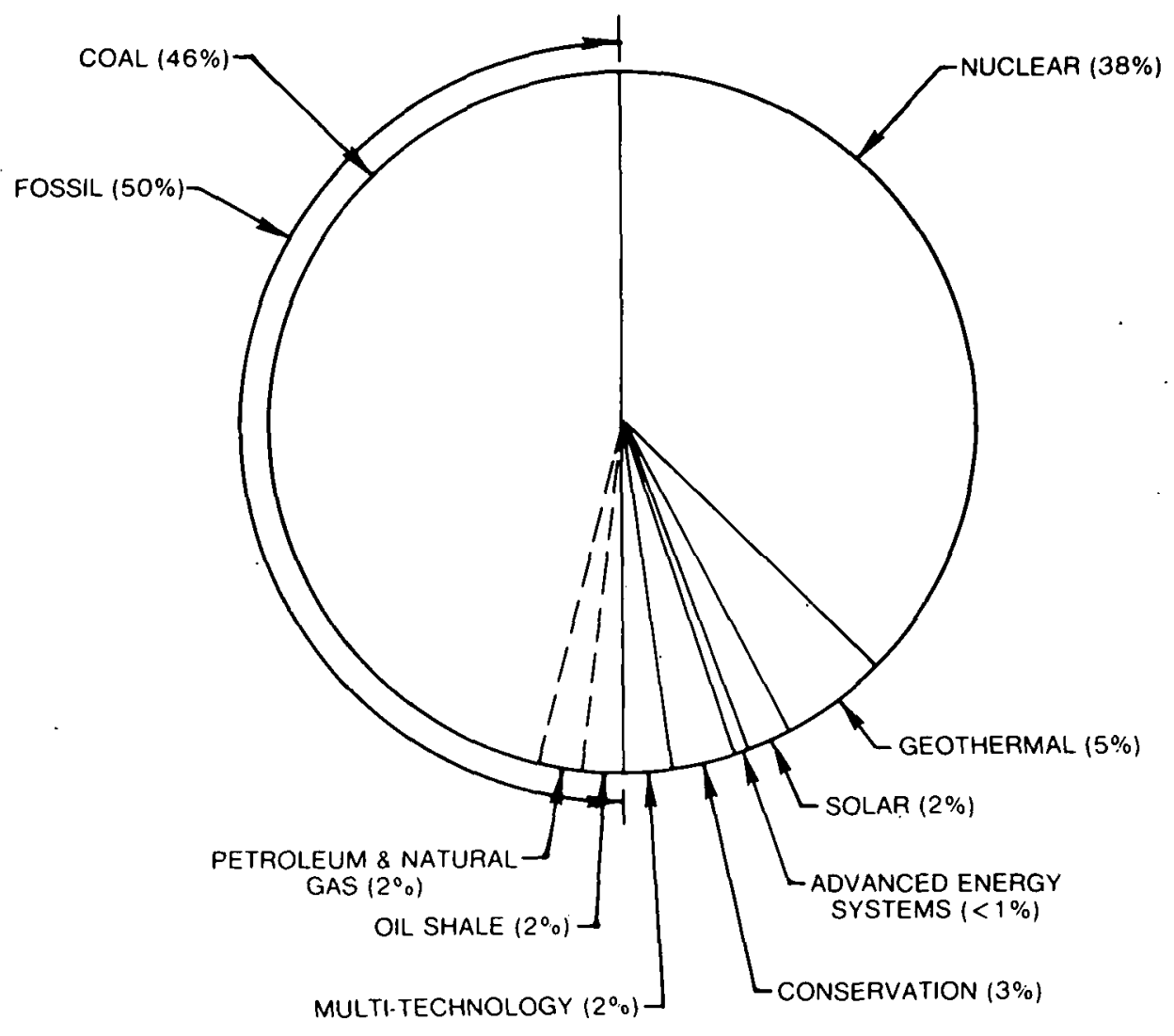

FIGURE IIL-2 Distribution of Total ERDA Environment Control Activities Related to FY 1977 Funding by Energy Category. 
TABLE III-2

CONSERVATITON ENVIRONMENTAL CONTROL ACTIVITIES RELATED FUNDING

\begin{tabular}{|l|c|c|}
\hline \multicolumn{1}{|c|}{ Division or Sub-Program } & $\begin{array}{c}\text { FY 1977 Funding Allocation } \\
\text { Related to Environmental } \\
\text { Control Activities }\end{array}$ & $\begin{array}{c}\text { Portion of Total FY 1977 } \\
\text { Budget Related to } \\
\text { Environmental Control } \\
\text { Activities } \\
\text { (Percent)* }\end{array}$ \\
\hline Buildings \& Community Systems & (\$ in thousands) & 1.9 \\
$\begin{array}{l}\text { Conservation Research \& } \\
\text { Technology } \\
\text { Electric Energy Systems }\end{array}$ & 520 & 6.4 \\
$\begin{array}{l}\text { Energy Storage Systems } \\
\text { Industrial Energy Conservation }\end{array}$ & 813 & 13.6 \\
$\begin{array}{l}\text { Transportation Energy } \\
\text { Conservation }\end{array}$ & 409 & 3.3 \\
\hline Total & 512 & 3.3 \\
\hline
\end{tabular}

TOTAL AC FY 1977 Budget: $\$ 124,950,000$

* To nearest tenth of a percent 
TOTAL CONSERVATION FY 1977 FUNDING

RELATED TO ENVIRONMENTAL CONTROL: $\$ 5,984,000$

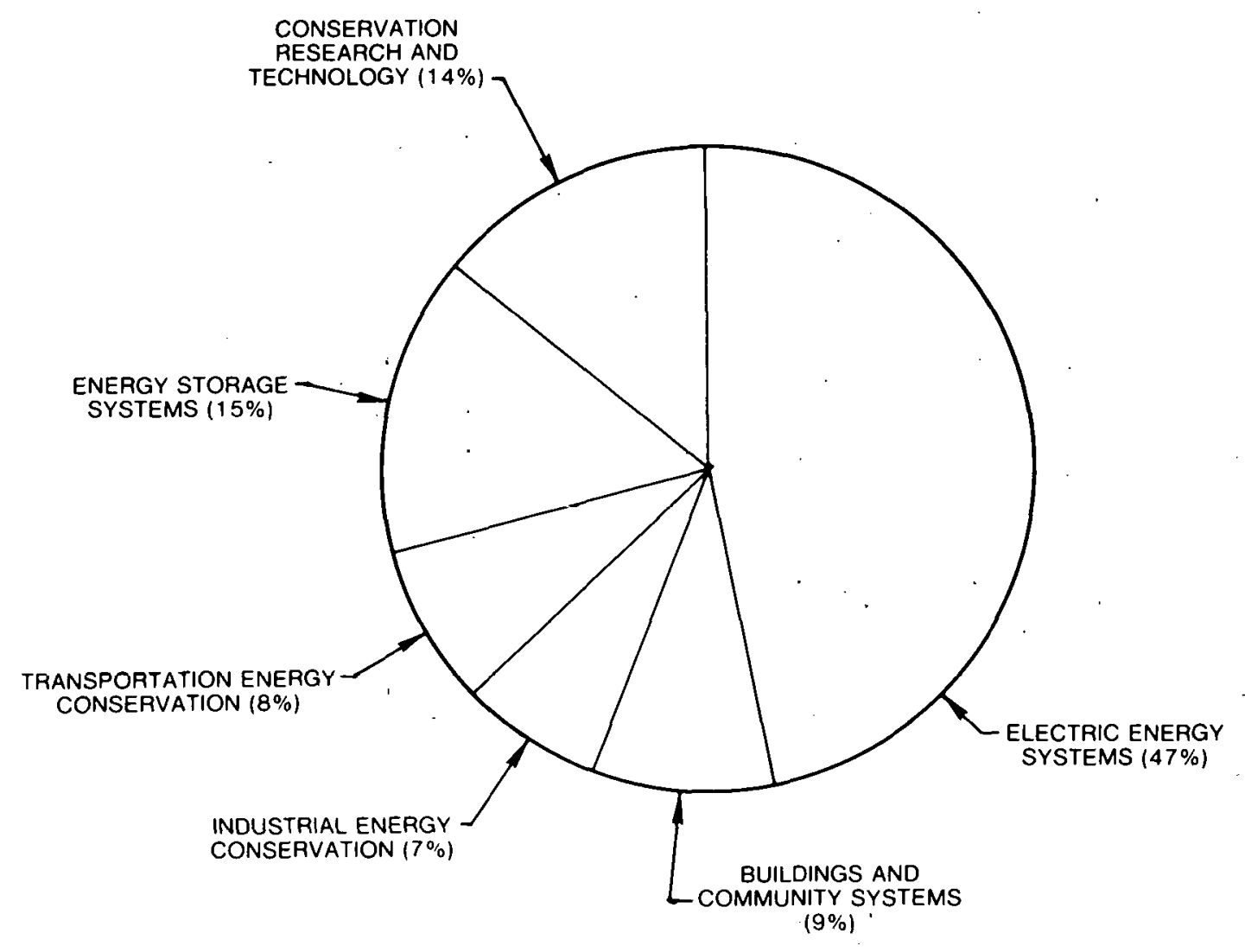

FIGURE III-3 Distribution of Environmental Control Technology Funding in the Office of the Assistant Administrator for Conservation. 
TABLE III- 3

FOSSIL ENERGY

ENVIRONMENTAL CONTROL ACTIVITIES RELA TED FUNDING

\begin{tabular}{|l|c|c|}
\hline & $\begin{array}{c}\text { FY 1977 Funding Allocation } \\
\text { Related to Environmental } \\
\text { Control Activities }\end{array}$ & $\begin{array}{c}\text { Portion of Total FY 1977 } \\
\text { Budget Related to } \\
\text { Environmental Control } \\
\text { Activities }\end{array}$ \\
\hline Coal & $(\$$ in thousands $)$ & (Percent)* \\
Oil Shale and In Situ Technology & 81,897 & 20.0 \\
Petroleum and Natural Gas & 1,820 & 5.9 \\
\hline Total & 2,477 & 5.7 \\
\hline
\end{tabular}

TOTAL AFE FY 1977 Budget: $\$ 483,145,000$

* To nearest tenth of a percent 
TOTAL FOSSIL ENERGY FY 1977 FUNDING

RELATED TO ENVIRONMENTAL CONTROL TECHNOLOGY: $\$ 86,194,000$

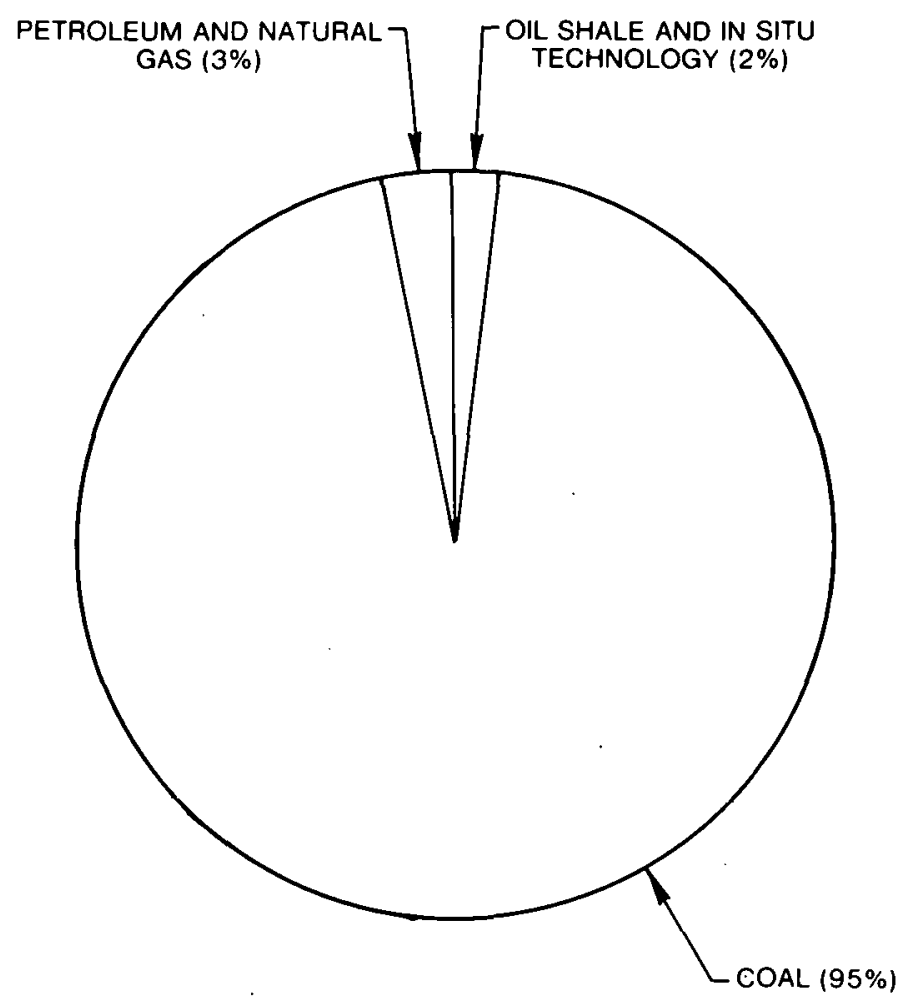

FIGURE IIL-4 Distribution of Environmental Control Technology Funding in the Office of the Assistant Administrator for Fossil Energy. 
COAL PROGRAM

ENVIRONMENTAL CONTROL ACTIVITIES RELA TED FUNDING

\begin{tabular}{|c|c|c|}
\hline Coal Sub-Program & $\begin{array}{l}\text { FY } 1977 \text { Funding Allocation } \\
\text { Related Environmental } \\
\text { Control Activities } \\
(\$ \text { in thousands })\end{array}$ & $\begin{array}{l}\text { Portion of Total FY } 1977 \\
\text { Budget Related to } \\
\text { Environmental Control } \\
\text { Activities } \\
\text { (Percent)* }\end{array}$ \\
\hline Liquefaction & 29,794 & 40.9 \\
\hline High-BTU Gasification & 7,781 & .17 .1 \\
\hline Low-BTU Gasification & 8,231 & 24.9 \\
\hline Advanced Power Systems & 1,769 & 7.9 \\
\hline Direct Combustion & 20,782 & 40.0 \\
\hline $\begin{array}{l}\text { Advanced Research \& Support } \\
\text { Technology }\end{array}$ & 4,301 & $\because 11.6$ \\
\hline Demonstration Plants & 5,795 & $10: 9$ \\
\hline Magnetohydrodynamics & 3,444 & 9.8 \\
\hline Total & 81,897 & 20.0 \\
\hline
\end{tabular}

* To nearest tenth of a percent 
TOTAL COAL PROGRAM FY 1977 FUNDING

RELATED TO ENVIRONMENTAL CONTROL: $\$ 81,897,000$

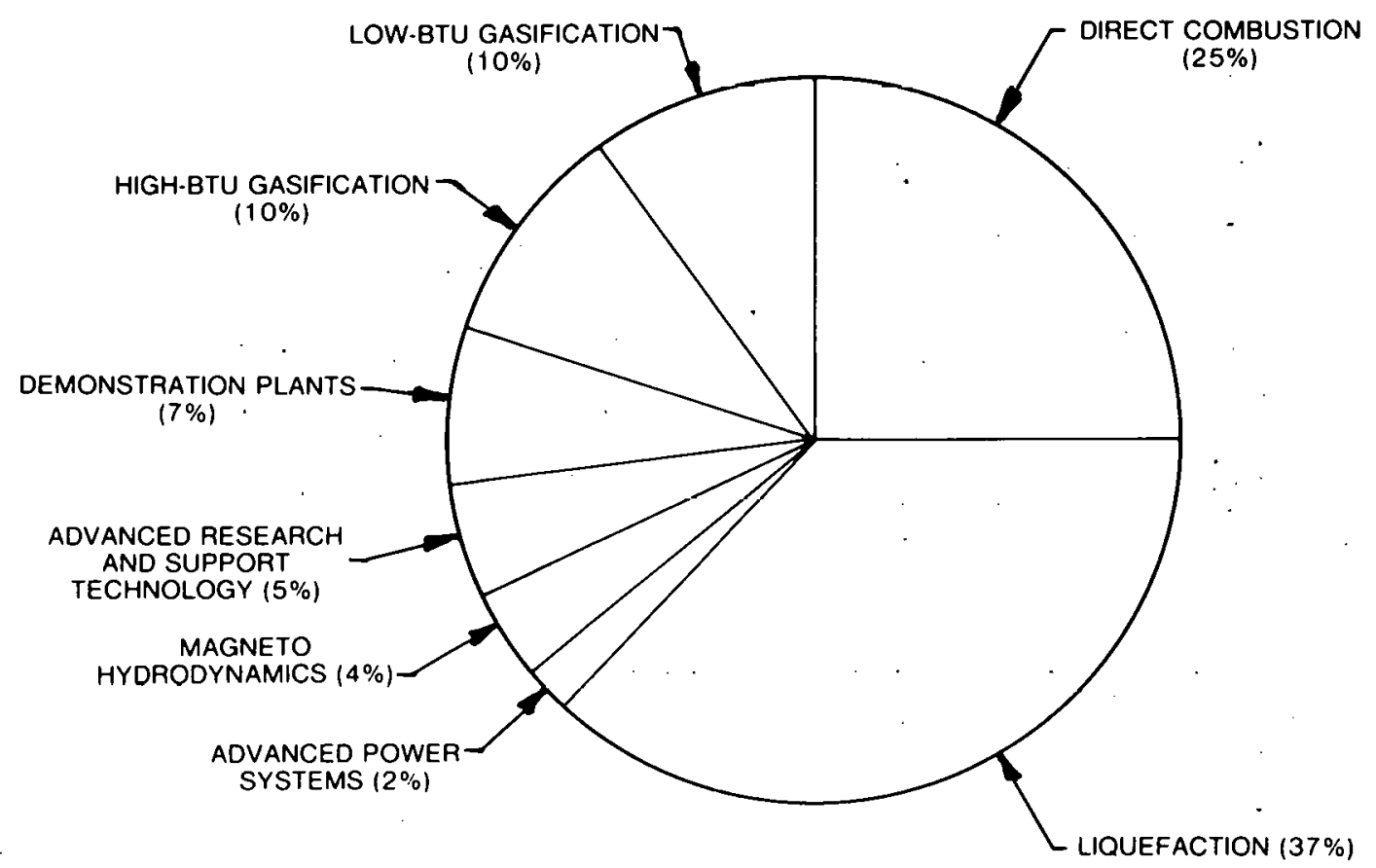

FIGURE II-5 Distribution of Environmental Control Technology Funding in the Coal Program within the Office of the Assistant Administrator for Fossil Energy. 
TABLE III- 5

NUCLEAR ENERGY

ENVIRONMENTAL CONTROL ACTIVITIES RELATED FUNDING

\begin{tabular}{|c|c|c|}
\hline & $\begin{array}{c}\text { FY 1977 Funding Allocation } \\
\text { Related to Environmental } \\
\text { Control Activities }\end{array}$ & $\begin{array}{c}\text { Portion of Total FY 1977 } \\
\text { Budget Related to } \\
\text { Environmental Control } \\
\text { Activities }\end{array}$ \\
\hline Division or Sub-Program & (Percent)* \\
\hline $\begin{array}{l}\text { Naval Reactors } \\
\text { Nuclear Research and Applications } \\
\text { Reactor Development and } \\
\text { Demonstration } \\
\begin{array}{l}\text { Uranium Resources and Enrichment } \\
\text { Waste Management, Production, } \\
\text { and Reprocessing }\end{array}\end{array}$ & 0 & 0 \\
\hline Total & 4,092 & 1.3 \\
\hline
\end{tabular}

TOTAL ANE FY 1977 Budget: $\$ 2,491,406,000$

* To nearest tenth of a percent 
TOTAL NUCLEAR ENERGY FY 1977 FUNDING

RELATED TO ENVIRONMENTAL CONTROL: $\$ 62,195,000$

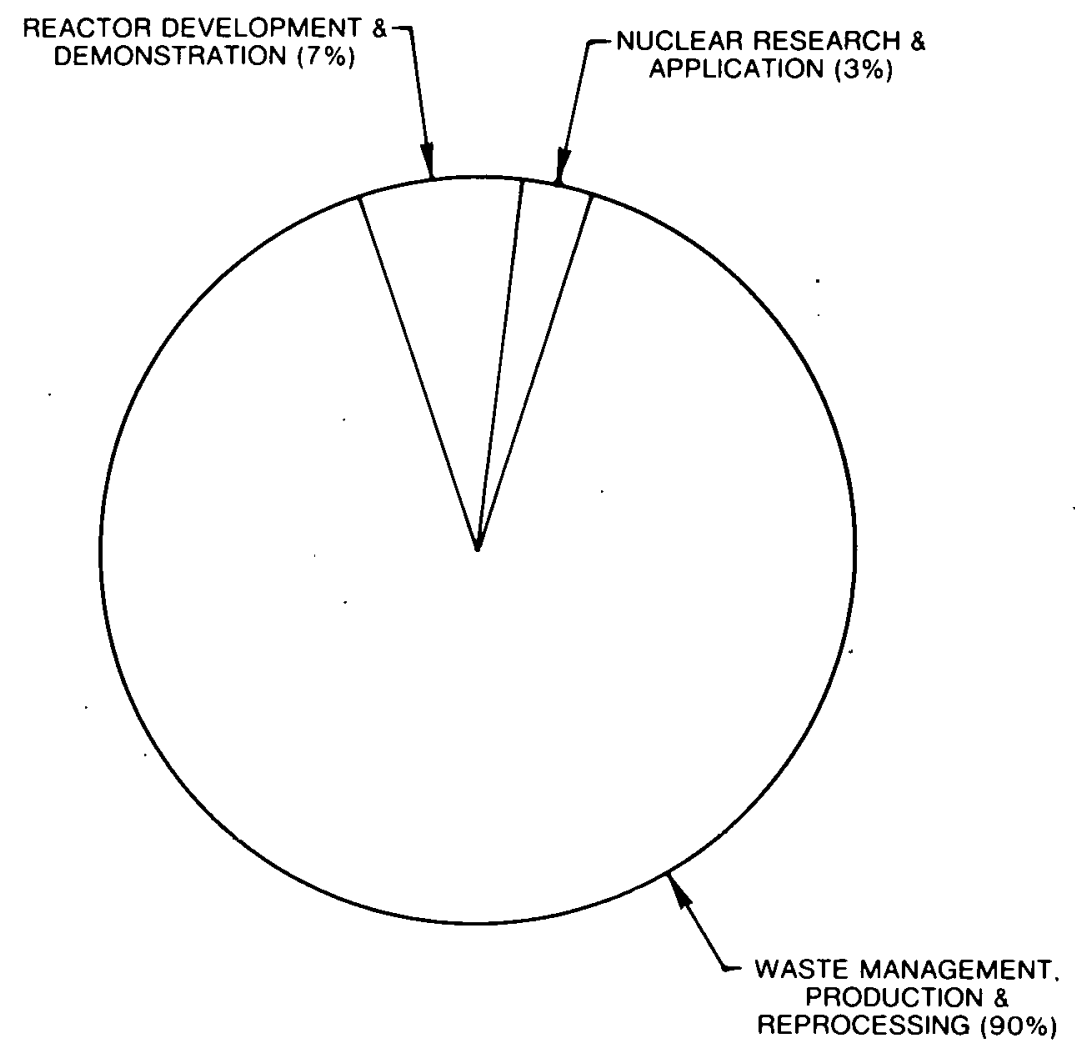

FIGURE IIH Distribution of Environmental Control Technology Funding in the Office of the Assistant Administrator for Nuclear Energy. 
TABLE III-6

SOLAR, GEOTHERMAL, AND ADVANCED ENERGY SYSTEMS ENVIRONMENTAL CONTROL ACTIVITIES RELATED FUNDING

\begin{tabular}{|l|c|c|}
\hline & $\begin{array}{c}\text { FY 1977 Funding Allocation } \\
\text { Related to Environmental } \\
\text { Control Technology }\end{array}$ & $\begin{array}{c}\text { Portion of Total FY 1977 } \\
\text { Budget Related to } \\
\text { Environmental Control } \\
\text { Technology }\end{array}$ \\
Division or Sub-Program & $(\$$ in thousands $)$ & $\begin{array}{c}\text { (Percent)* } \\
\text { Geothermal Energy }\end{array}$ \\
Magnetic Fusion Energy & 8,771 & 17.9 \\
Physical Research & 780 & 0.3 \\
Solar Energy & 100 & 0.1 \\
\hline Total & 2,686 & 1.4 \\
\hline
\end{tabular}

TOTAL ASGA FY 1977 Budget: $\$ 874,910,000$

* To nearest tenth of a percent 
TOTAL SOLAR, GEOTHERMAL, AND ADVANCED ENERGY SYSTEMS FY 1977 FUNDING RELATED TO ENVIRONMENTAL CONTROL TECHNOLOGY: $\$ 12,337,000$

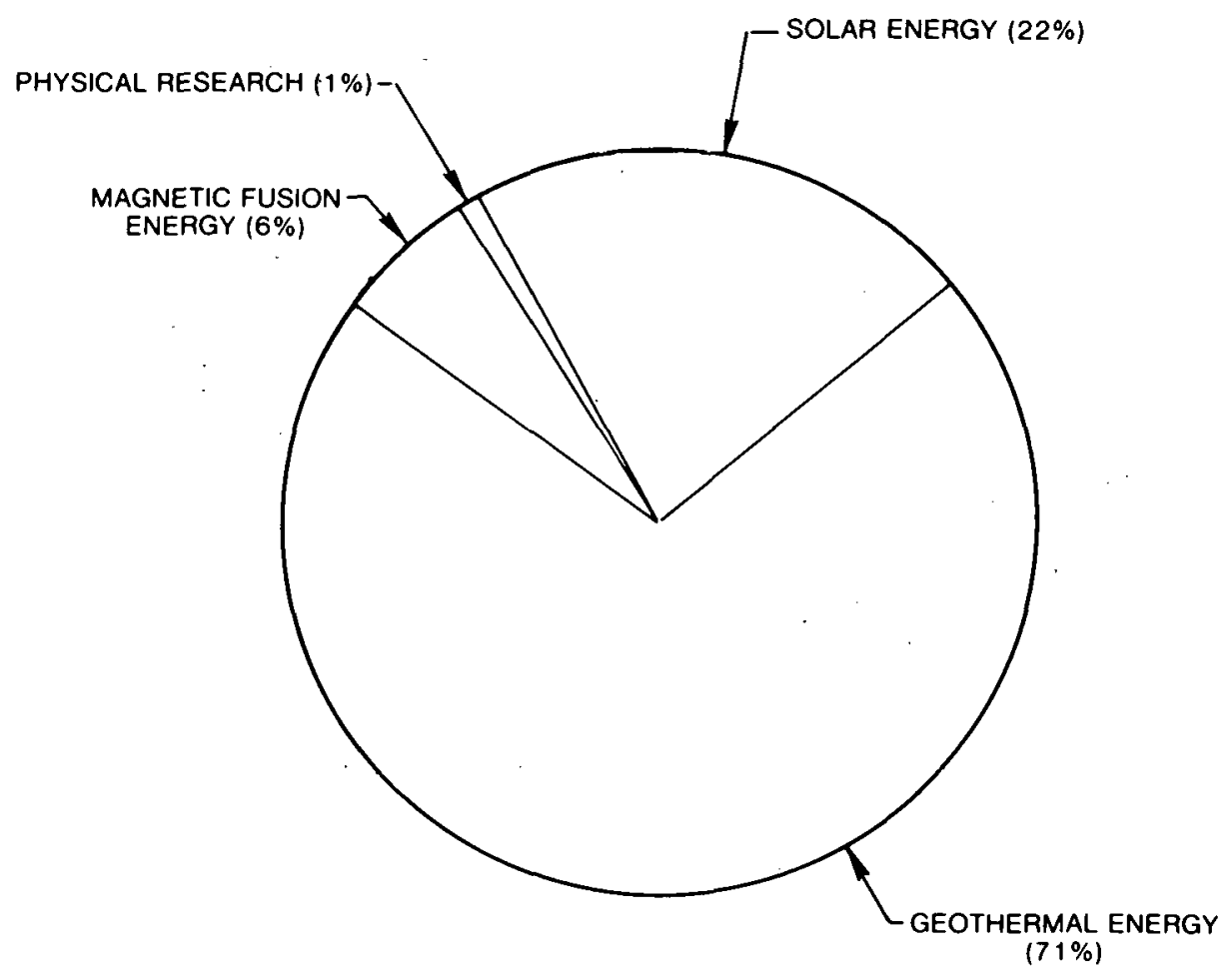

FIGURE IIF7 Distribution of Environmental Control Technology Funding in the Office of the Assistant Administrator for Solar, Geothermal, and Advanced Energy Systems. 
TABLE III-7

ENVIRONMENT AND SAFETY

ENVIRONMENTAL CONTROL ACTIVITIES RELATED FUNDING

\begin{tabular}{|l|c|c|}
\hline \multicolumn{1}{|c|}{ Division or Sub-Program } & $\begin{array}{c}\text { FY 1977 Funding Allocation } \\
\text { Related to Environmental } \\
\text { Control Activities }\end{array}$ & $\begin{array}{c}\text { Portion of Total FY 1977 } \\
\text { Budget Related to } \\
\text { Environmental Control } \\
\text { Activities }\end{array}$ \\
\hline $\begin{array}{l}\text { Biomedical and Environmental } \\
\text { Research } \\
\text { Environmental Control Technology }\end{array}$ & 1,196 & 0.7 \\
(Percent)*
\end{tabular}

TOTAL AES FY 1977 Budget: $\$ 222,819,000$

* To nearest tenth of a percent 
ENVIRONMENT AND SAFETY

BREAKDOWN OF FY 1977 FUNDING RELATED TO

ENVIRONMENTAL CONTROL ACTIVITIES

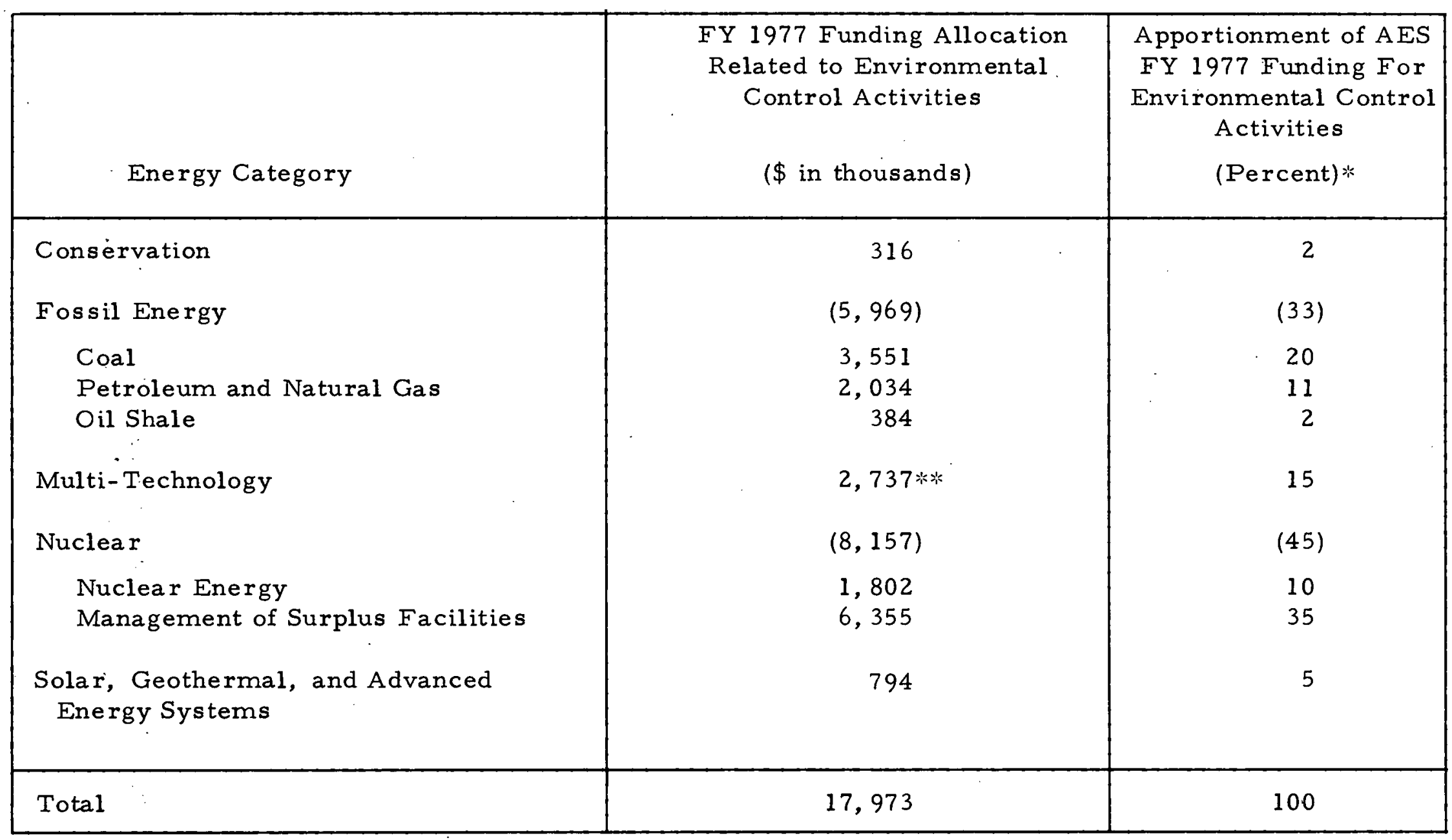

* To nearest whole percent

*** Includes $\$ 2,330,000$ for Energy Materials Transportation (13\%) 
TOTAL ENVIRONMENT AND SAFETY FY 1977 FUNDING

RELATED TO ENVIRONMENTAL CONTROL TECHNOLOGY: $\$ 17,973,000$

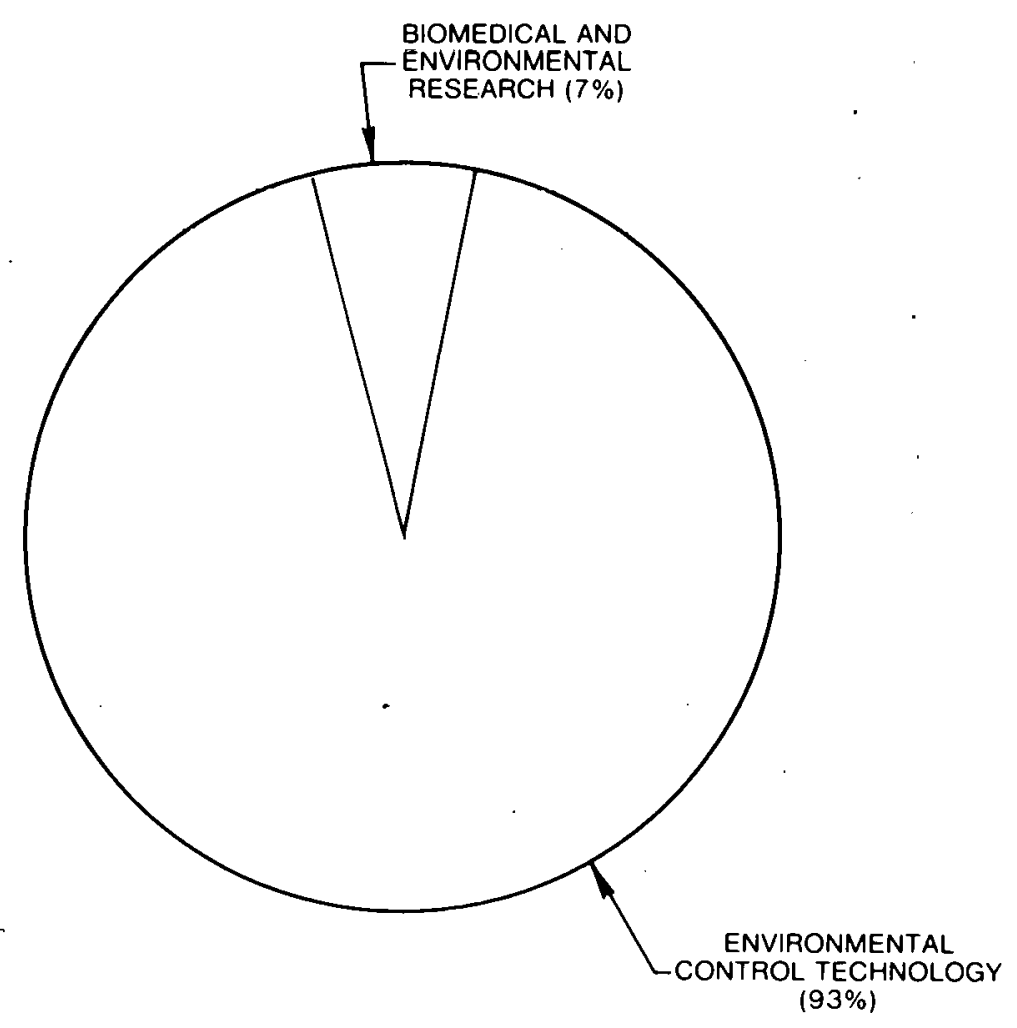

FIGURE IIL-8 Distribution of Environmental Control Technology Funding in the Office of the Assistant Administrator for Environment and Safety. 
TOTAL ENVIRONMENT AND SAFETY FY 1977 FUNDING RELATED TO ENVIRONMENTAL CONTROL TECHNOLOGY: $\$ 17,973,000$

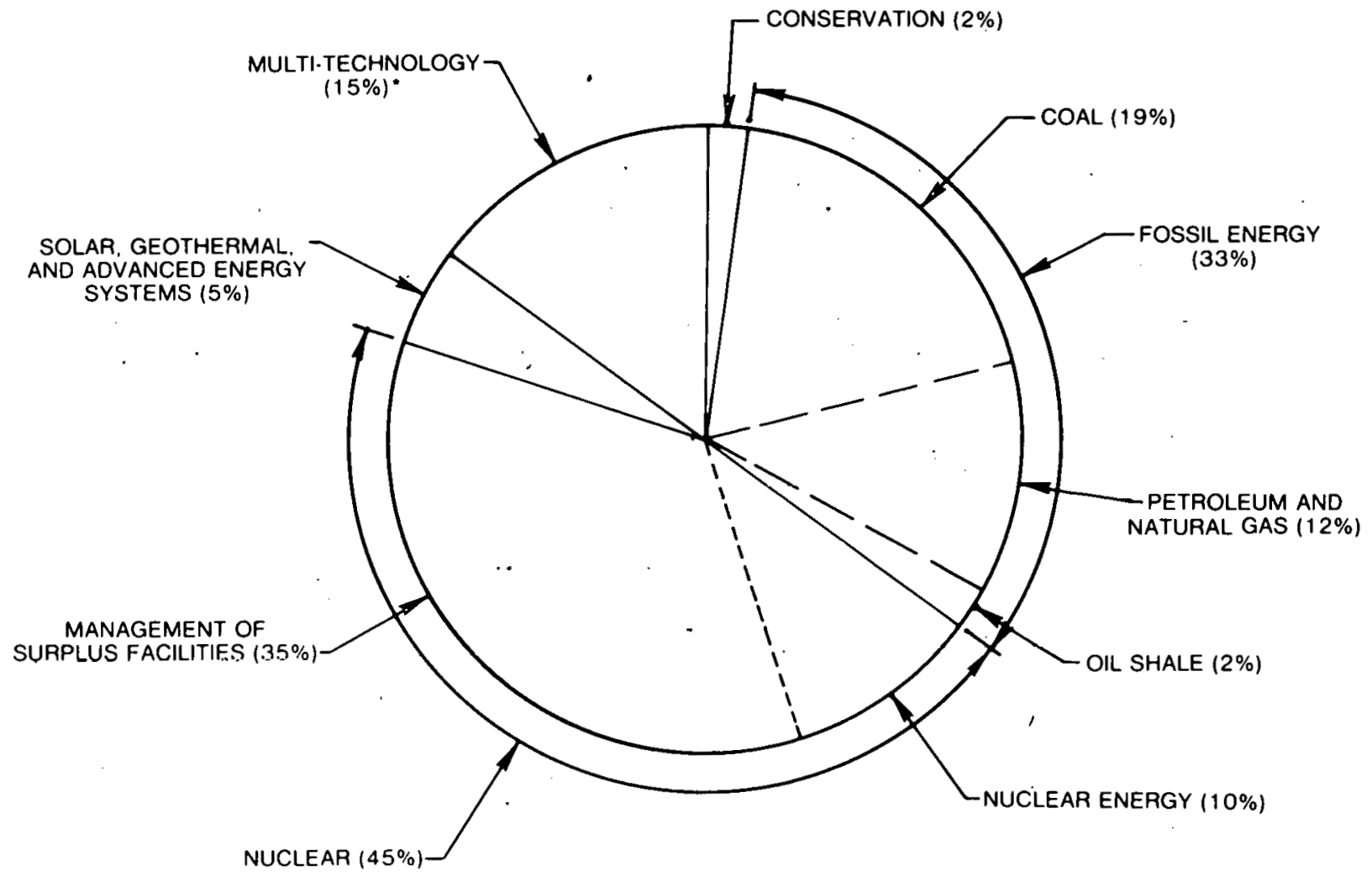

- INCLUDES I3\% FOR ENERGY MATERIALS TRANSPORTATION

FIGURE IIF-9 Distribution of Environmental Control Technology Funding by Energy Category in the Office of Assistant Administrator for Environment and Safety. 


\section{Results}

To aid in obtaining the necessary consistent inputs to the inventory, specific ground rules and requirements were established. The primary ground rule involved the definition of environmental control which is:

"Those activities directed at Research, Development, and Demonstration of processes, procedures, systems, subsystems, and strategies which directly or indirectly eliminate, minimize, or mitigate environmental impacts."

Examples:

- Add-on Process (e.g., Claus Unit for Tailgas Cleanup)

- Energy Process Design (e.g., Fluidized-Bed Combustion of Coal)

- $\quad$ Energy Process "Tuning" Efforts (e.g., Reuse of Waste Water)

The criteria for activity applicability to environmental control was as defined in Table IV-1. It was recognized that a clear "black-and-white" set of guidelines was not possible across the board for all energy RD\&D programs. A series of panel sessions was conducted to reconcile the vast majority of applicability uncertainties.

As part of the input requirements, a standardized tabular format was developed. This table, as depicted in the following sub-sections, provides the following information:

a. A heading defining the administration and the main title for the specific sessions.

b. "Project/Element" Title - A descriptive title including main words describing the principal nature of the project and element. A "project" was categorized as a discrete, definitely formulated task and an "element" was a division of a program consisting of two. or more projects which are technology or subject interrelated.

c. A checklist to define the primary categories of the project and element relationship to environmental control technology such as research, studies, design, etc.

d. A description of the relationship of the project or element to environmental control technology. For example, the use of scrubbers, filters, washers, or precipitators to remove noxious gases or particulates from a combustion process.

e. Finally, the FY 1977 funding allocation related to environmental control technology. Funding was to include operating, capital equipment, and plant Budget Outlay $(\mathrm{B} / \mathrm{O})$ dollars that were determined to be related to environmental control technology.

The following sub-sections describe the detailed inputs obtained. Missing from the listings are inputs from National Security (ANS) for which it was agreed that attempting to include ANS projects would not serve the purpose of the inventory. This was due to the fact that an extremely small portion of their funding might have environmental control aspects. 
TABLE IV-I

CRITERIA FOR APPLICABILITY TO ENVIRONMENTAL CONTROL TECHNOLOGY

\section{CATEGORY}

MAJOR FACILITIES

PROCESS DESIGN

RESEARCH, ANALYSES AND STUDIES

ASSESSMENTS

$\tilde{w}$

PROCESS STREAM SAMPLING AND ANALYSIS

TRAINING PROGRAMS, SEMINARS, ETC.

\section{APPLICABLE}

RD\&D

ENVIRONMENTAL IMPACT MITIGATION

DIRECTLY OR INDIRECTLY NECESSARY TO CONTROL ENVIRONMENT AL IMPACT

PARTIALLY OR DIRECTLY RELATED TO DETERMINING THE NEED FOR NEW OR ADDITIONAL ENVIR ONMENTAL CONTROLS

EVALUATE OR DETERMINE THE EFFECTIVENESS AND PERFORMANCE OF EXISTING OR ANTICIPATED ENVIRONMENTAL CONTROL PROVISIONS

RELATED TO ENVIRON MENTAL CONTROL

\section{NOT APPLICABLE}

ENERGY PRODUCTION OPERATIONAL FACILITIES (e.g. , POWER STATIONS AND OFFICE SPACE)

ASSOCIATED SOLELY WITH PROCESS OPERATIONS AND RELIABILITY

DO NOT IMPACT THE ENVIRONMENT

TO EVALUATE THE CHARACTERISTICS OF A PROCESS THAT DOES NOT IMPACT THE ENVIRONMENT

ROUTINE OPERATIONAL MONITORING

FOR ENERGY DEVELOPMENT THAT IS NOT COINCIDENT WITH ENVIRONMENTAL CONTROL TECHNOLOGY 


\section{A. Conservation}

Working meetings were held with the divisions within AC. Primarily these meetings were for the purpose of clarifying and defining the needs of the inventory and the requirements for completing the inputs. Each of the six divisions within Conservation submitted tabular data for review. Comments, as required, were coordinated and in all cases resolved. Tables IV-2 through IV-7 are the final product and constitute the AC portion of the environmental control technology inventory.

The total AC FY 1977 funding to environmental control activities was $\$ 5,984,000$. The Division of Electric Energy Systems projects accounts for 47 percent of that total mainly due to three projects in the electric field effects of power lines. The division of Energy Storage Systems (STOR) and Conservation Research and Technology (CONRT) account for 15 percent and 14 percent of the AC funding respectively. The STOR project with the highest funding is associated with conducting research into containment materials for hydrogen storage and transport. Within CONRT, there is no particular project that stands out; however, the majority of the related funding was in the area of combustion and fuels technology research to improve emission controls or to decrease the emissions. The Divisions of Buildings and Community Systems (BCS), Industrial Energy Conservation (INDUS), and Transportation Energy Conservation (TEC) were approximately equally divided in their funding levels for the remaining 24 percent of the AC total. The total number of $A C$ projects with environmental control aspects was over 70 with CONRT having the most at 21 and BCS with the least at 4.

The AC funding related to environmental control technology constituted 5 percent of the total FY 1977 funding for AC. The objectives of AC are basically reflected in the relatively low percentage. These are: promotion of energy conservation, conversion of existing facilities and equipment, and development of new, energy-efficient methodologies and technologies. The first objective involves very little environmental control effort since it is directed towards consumer conservation and not energy development. The last two objectives do involve environmental control either by providing the same energy services with less energy input (less pollutants) or by the development of new techniques which more effectively utilize the available energy protentials. In either case, the control is by design and not as an add-on unit. 
TABLE IV - 2

PROJECTS WITH ENVIRONMENTAL CONTROL ASPECTS

ENERCY IECHNOLOCY: Conservation

PANEL SESSION: Buildings \& Community Systems

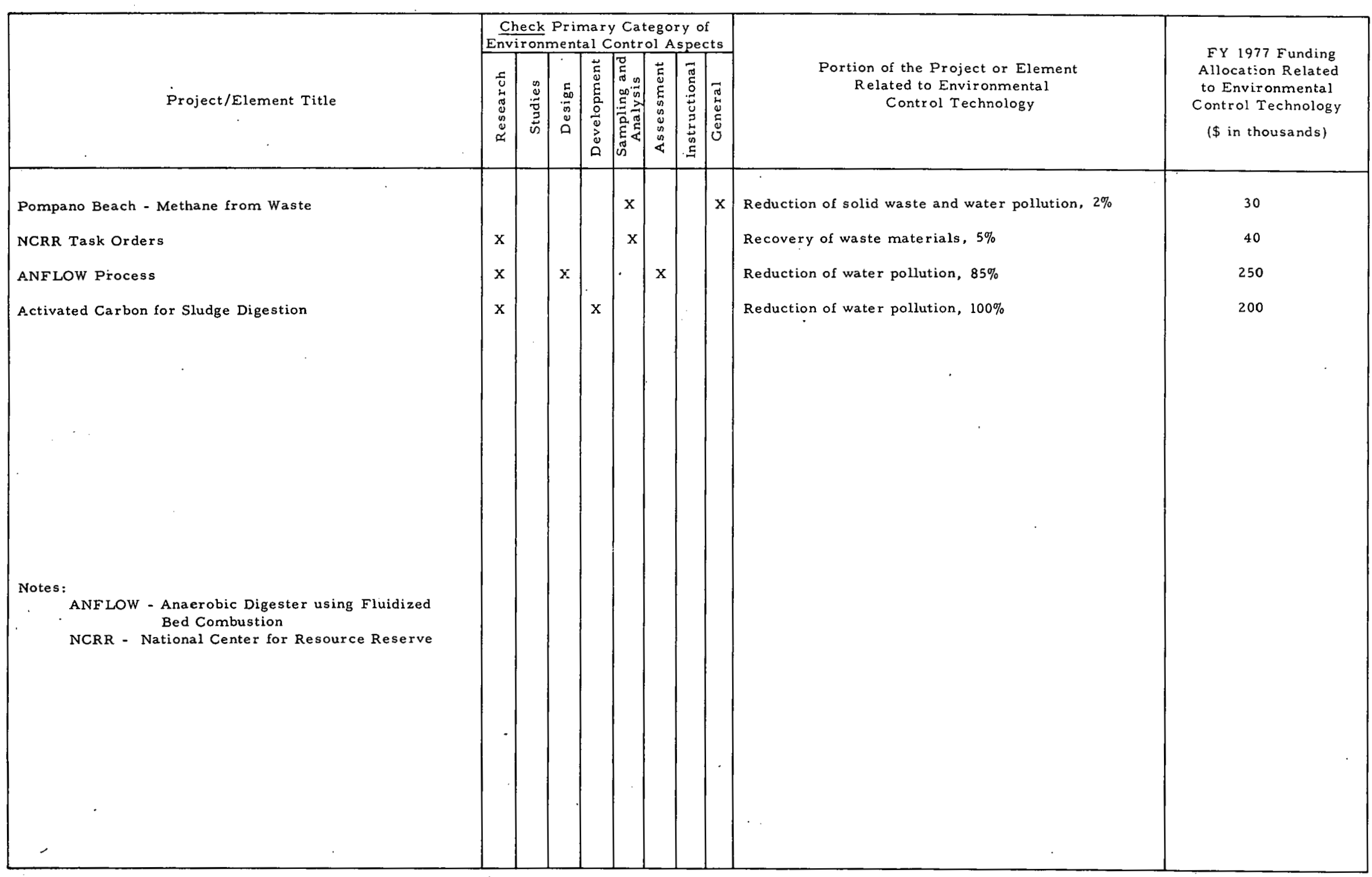


TABLE IV - 3

PROJECTS WITH ENVIRONMENTAL CONTROL ASPECTS

ENERGY TECHNOLCCY : Conservation

PANEL SESSION: Conservation Research and Technology

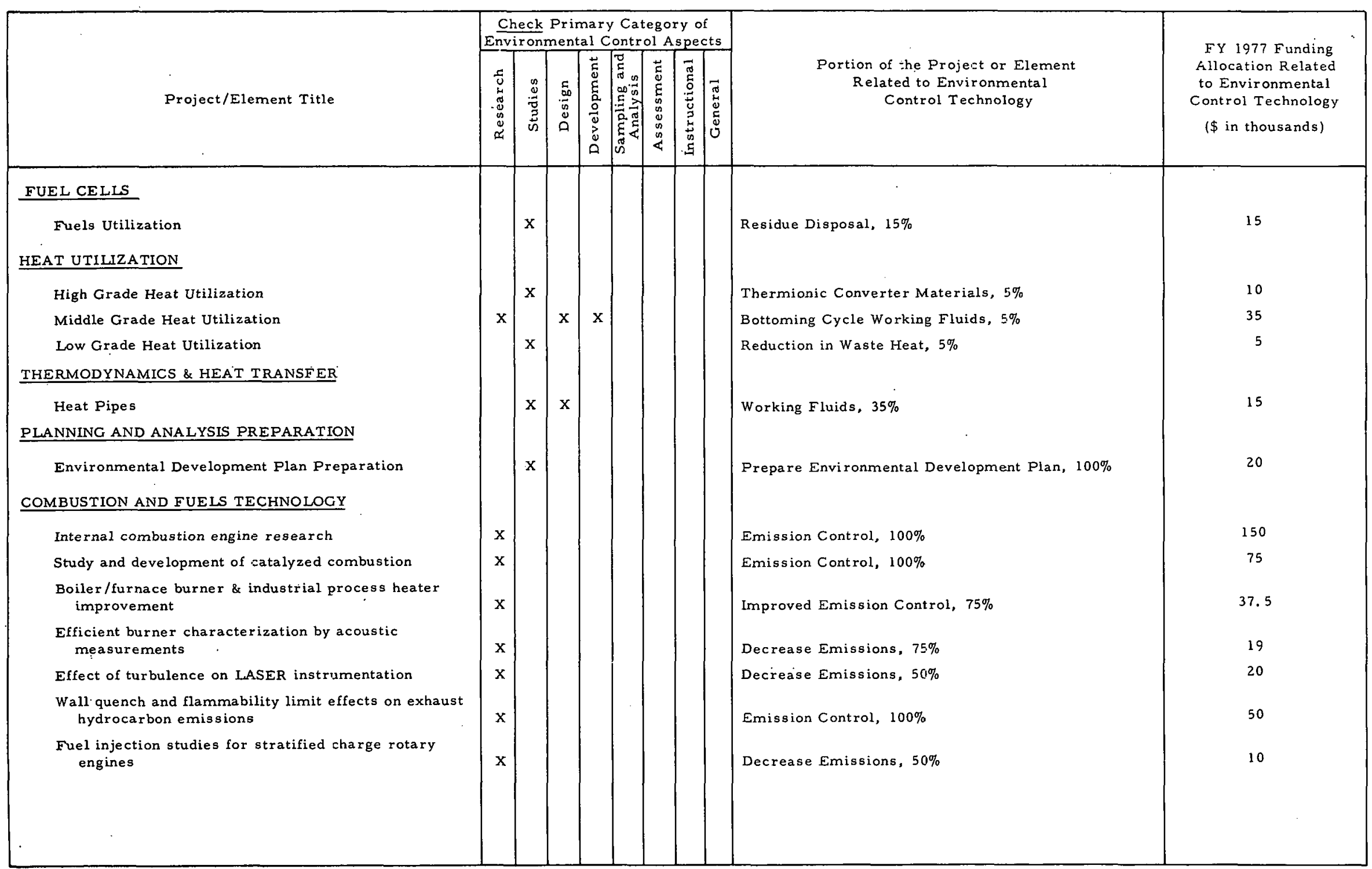


TABLE IV-3 (Cont)

PROJECTS WITH ENVIRONMENTAL CONTROL ASPECTS

ENERCY TICHNCLCCY: Conservation

PANEL SESSION: Conservation Research and Technology

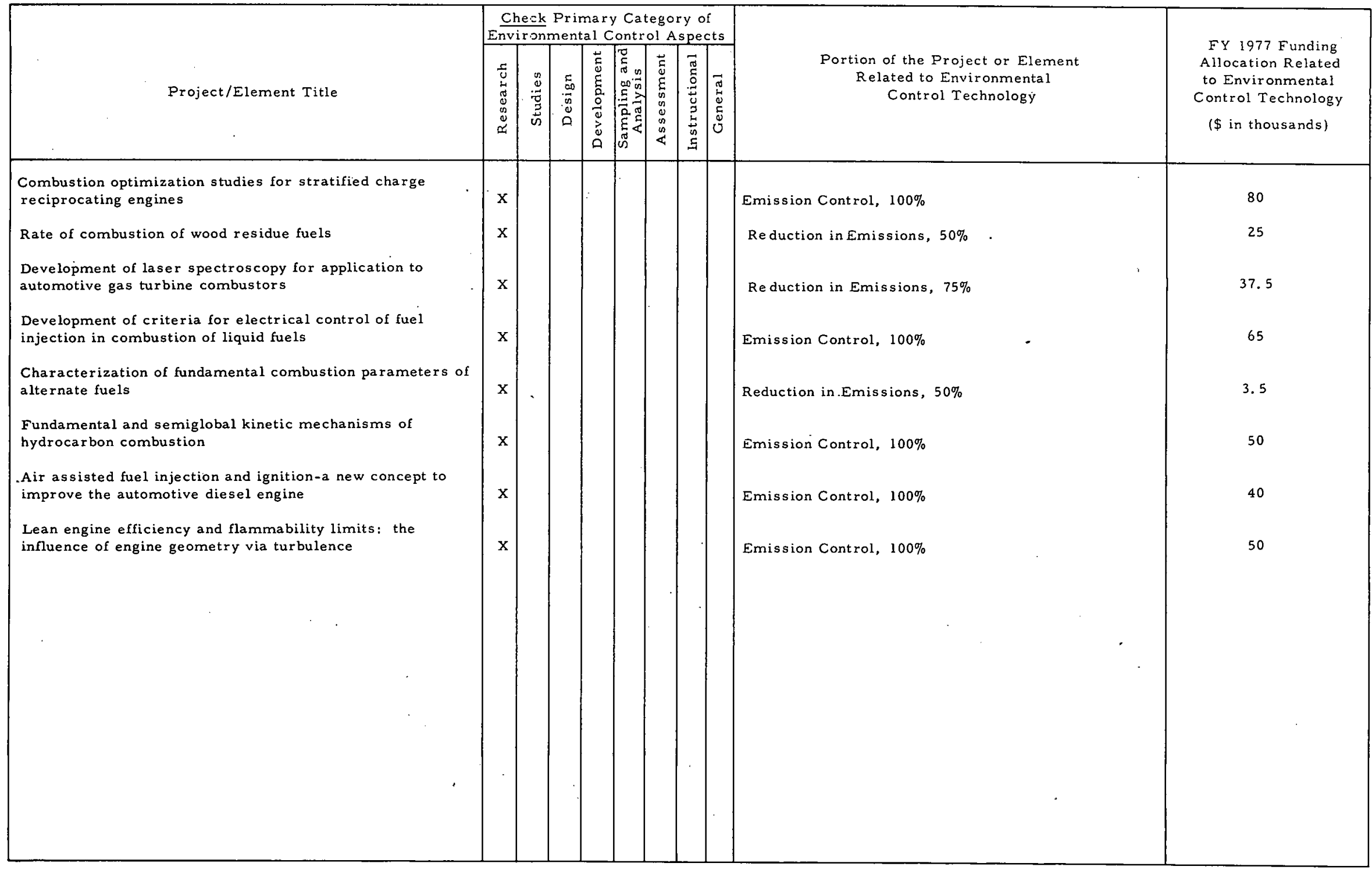


TABLE IV -4

PROJECTS WITH ENVIRONMENTAL CONTROL ASPECTS

ENERGY TECHNOLOGY: Conservation

PANEL SESSION: Electric Energy Systems

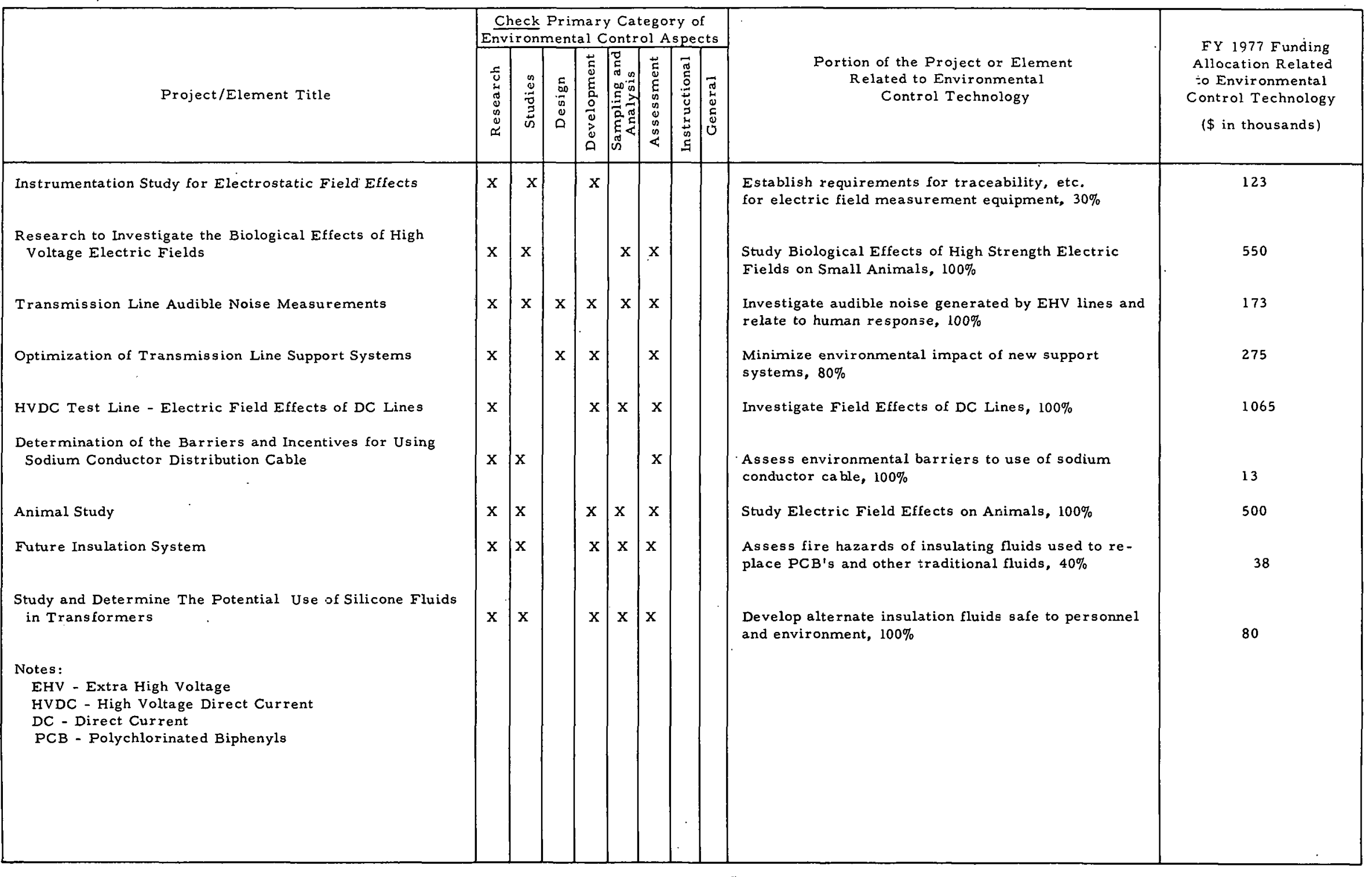


TABLE IV -5

PROJECTS WITH ENVIRONMENTAL CONTROL ASPECTS

ENERGY TECHNOLOGY: Conservation

PANEL SESSION: Energy Storage Systems

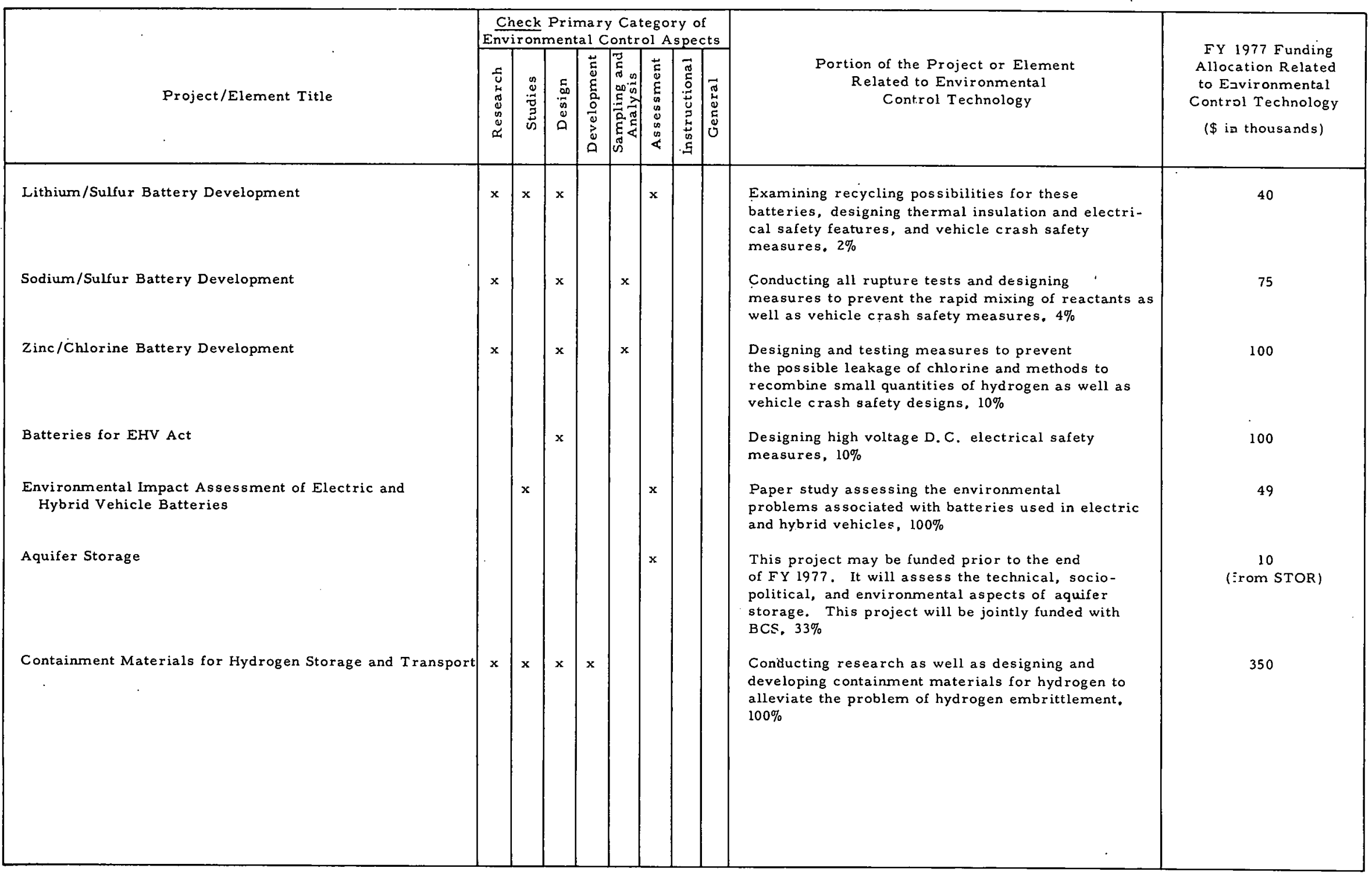


TABLE IV-5 (Cont)

PROJECTS WITH ENVIRONMENTAL CONTROL ASPECIS

ENERGY TECHNOLOGY: Conservation

PANEL SESSION: Energy Storage Systems

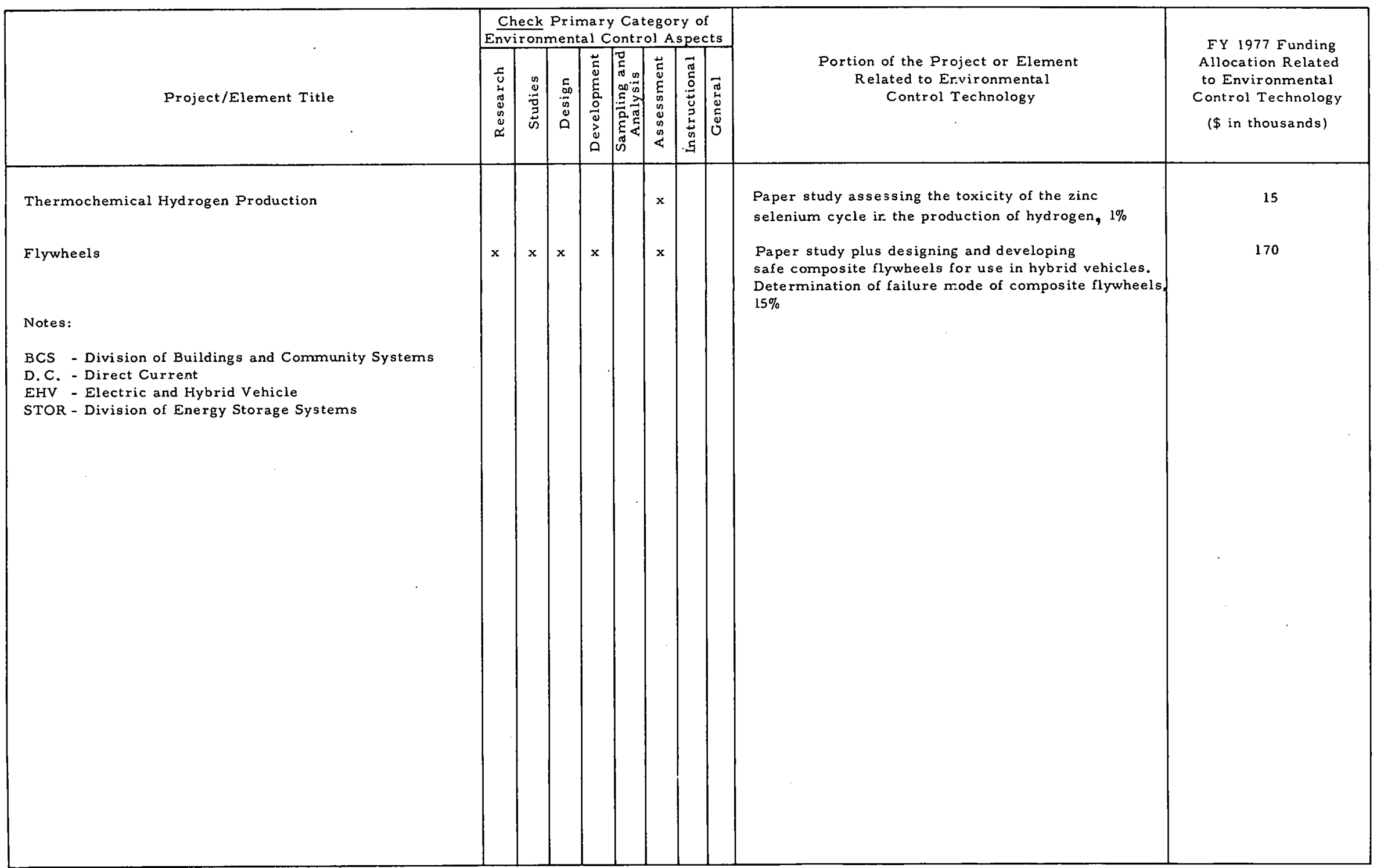


TABLE IV -6

PROJECTS WITH ENVIRONMENTAL CONTROL ASPECTS

ENERGY TECHNOLOGY: COnservation

PANEL SESSION: Industrial Energy Conservation

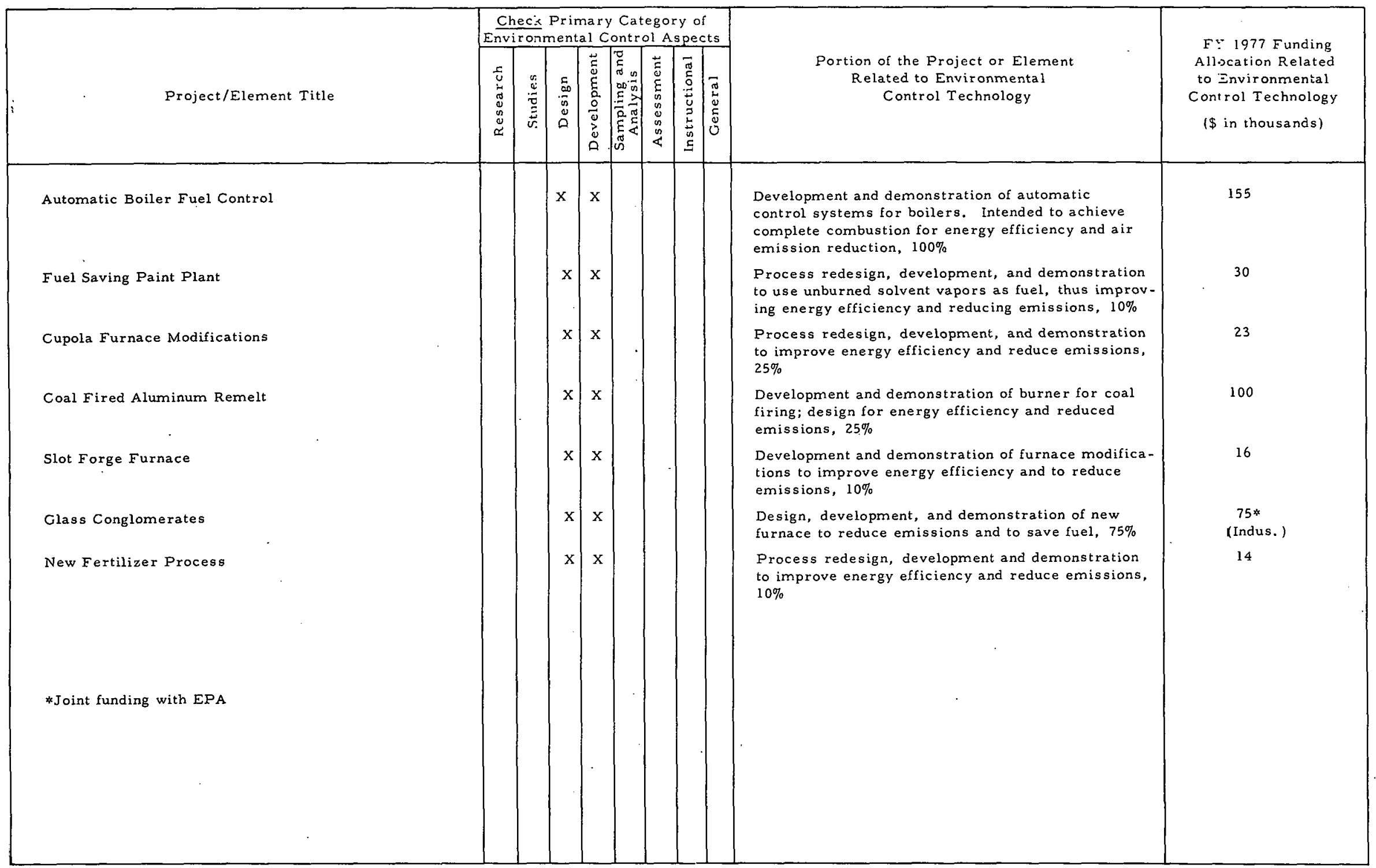


TABLE IV - ?

PROJECTS WITH ENVIRONMENTAL CONTROL ASPECTS

ENERGY TECHNOLOGY: Conservation

PANEL SESSION: Transportation Energy Conservation

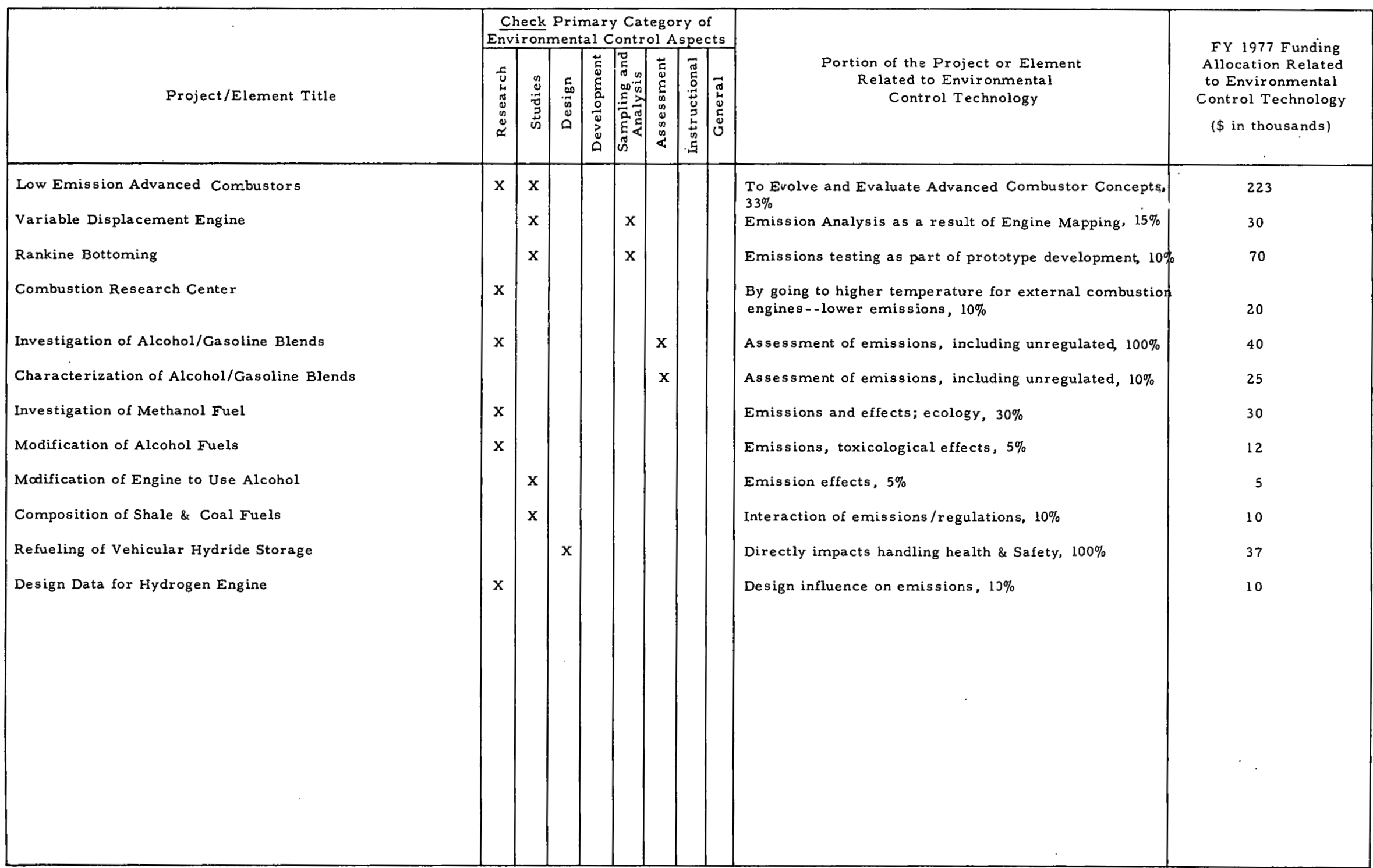




\section{B. Fossil Energy}

At their request, panel sessions with AFE were not held. Inputs to this inventory were received from AFE and are shown in Table IV-8 through IV-21 inclusive. The format is slightly different from the remainder of the report due to time limitations and AFE commitment conflicts.

In the AFE supplied tables a description of the portion of the category related to environmental control technology was not presented, therefore a detailed description of the environmental control activities is not possible. The major portion of the applicable funding was in the coal program which comprised 95 percent of the total AFE funding related to environmental control activities. The remaining 5 percent was associated with petroleum and natural gas ( 3 percent) and oil shale and in-situ technology ( 2 percent).

Within the coal program, liquefaction accounted for 37 percent of the total AFE related funding with solvent extraction processes $(\$ 21,150,000)$, followed by direct hydrogenation processes $(\$ 6,340,000)$ accounting for the majority of the liquefaction project activities related to environmental control technology. Direct combustion followed with 25 percent of the AFE total mainly in the areas of atmospheric fluidized-bed combustion $(\$ 10,582,000)$ and pressurized systems $(\$ 8,600,000)$. Gasification (high and low BTU) accounted for 20 percent, with the major funding related to environmental control technology noted in the development of gasification techniques and processes. The remainder (18 percent) of the coal program environmental control activities were, in the order of funding levels, associated with demonstration plants $(\$ 5,795,000)$, advanced research and support technology $(\$ 4,301,000)$, magnetohydrodynamics $(\$ 3,444,000)$, and advanced power systems $(\$ 1,769,000)$.

The petroleum and natural gas program (Tables IV-16 through IV-19) accounted for 3 percent $(\$ 2,477,000)$ of the total AFE funding related to environmental control technology. The environmental control activities in this program are almost entirely related to environmental studies and support.

The oil shale and in-situ technology program, Tables IV-20 and IV-21, comprised the remaining 2 percent $(\$ 1,820,000)$ of the AFE funding related to environmental control technology. These activities are all in the category of environmental support and supporting research. 
TABLE IV -8

ENVIRONMENTAL CONTROL ASPECTS OF FOSSIL ENERGY PROGRAM

PROGRAM: Coal

SUBPROGRAM: Liquefaction

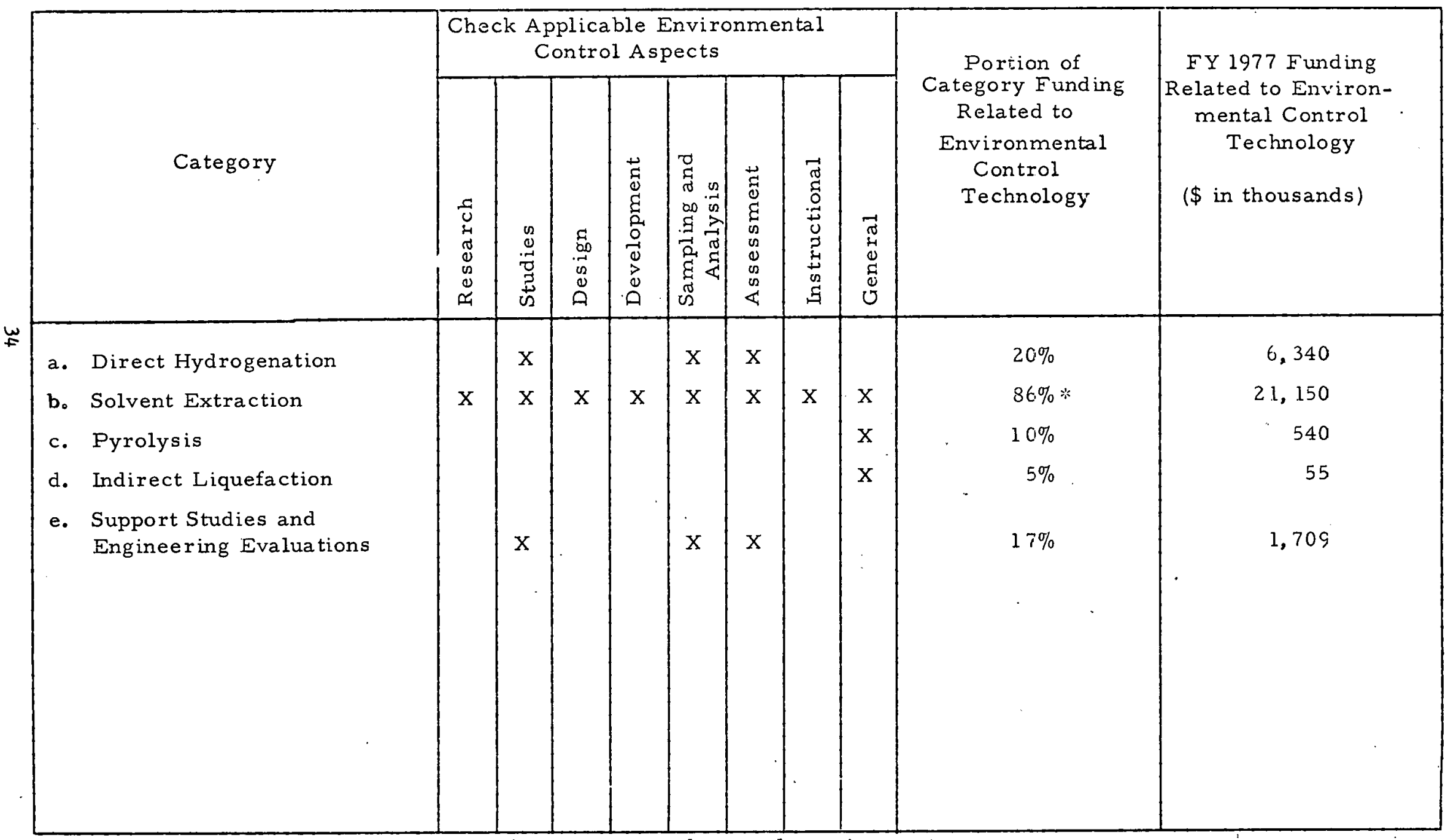

* Coal Cleaning via SRC associated with environmental control requirements. 
TABLE IV -9

ENVIRONMENTAL CONTROL ASPECTS OF FOSSIL ENERGY PROGRAM

PROGRAM: Coal

SUBPROGRAM: High-Btu Gasification

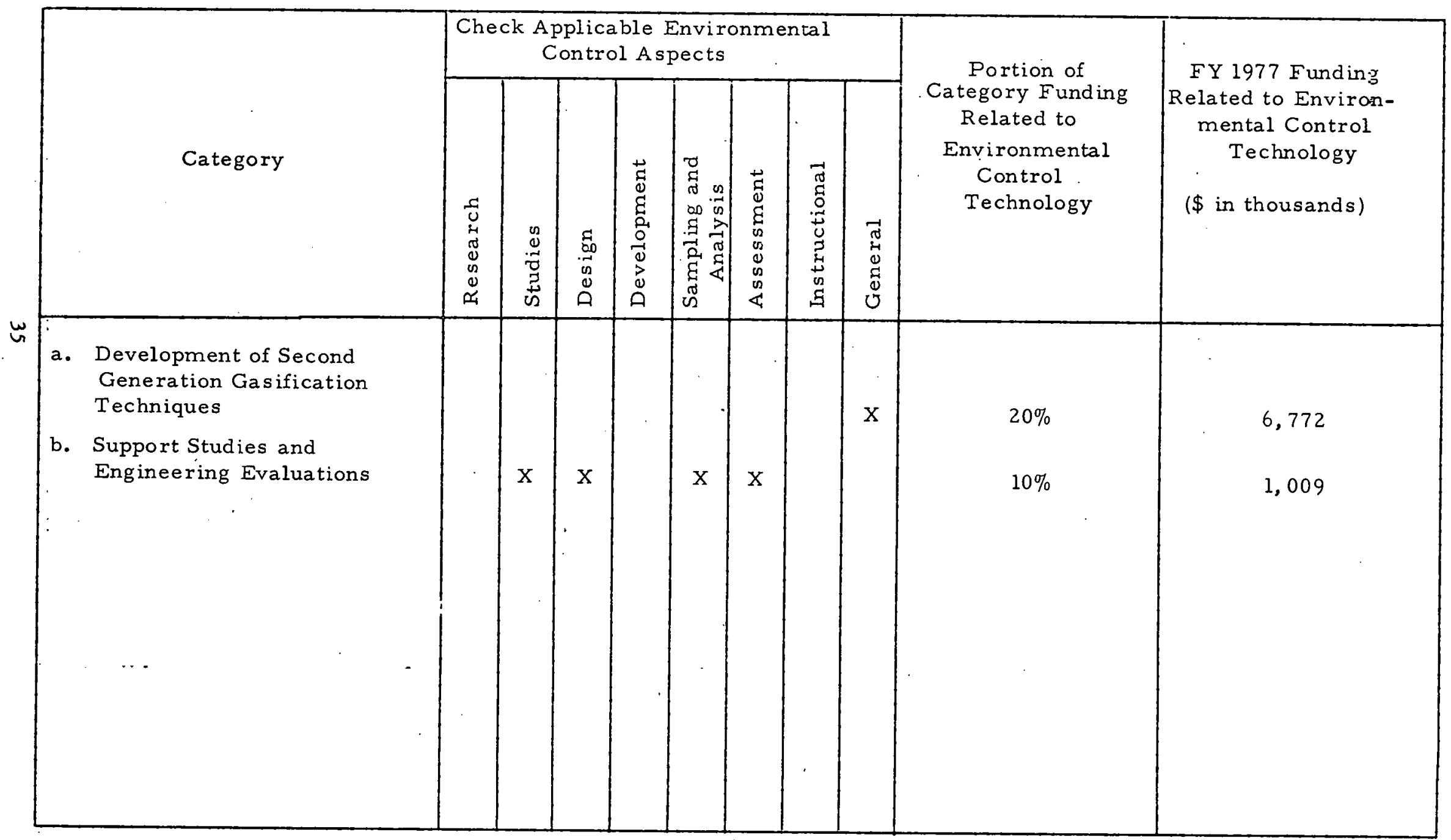


TABLE IV - 10

ENVIRONMENTAL CONTROL ASPECTS OF FOSSIL ENERGY PROGRAM

PROGRAM: Coal

SUBPROGRAM: Low-Btu Gasification

w

a. Gasification Processes

b. Support Studies and Engineering Evaluations
Portion of

Category Funding

Related to

Environmental

Control

Technology

तี

FY 1977 Funding

Related to Environ-

mental Control

Technology

( $\$$ in thousands)

5,530

$50 \%$

2,701 
TABLE IV -11

ENVIRONMENTAL CONTROL ASPECTS OF FOSSIL ENERGY PROGRAM

PROGRAM: Coal

SUBPROGRAM: Advanced Power Systems

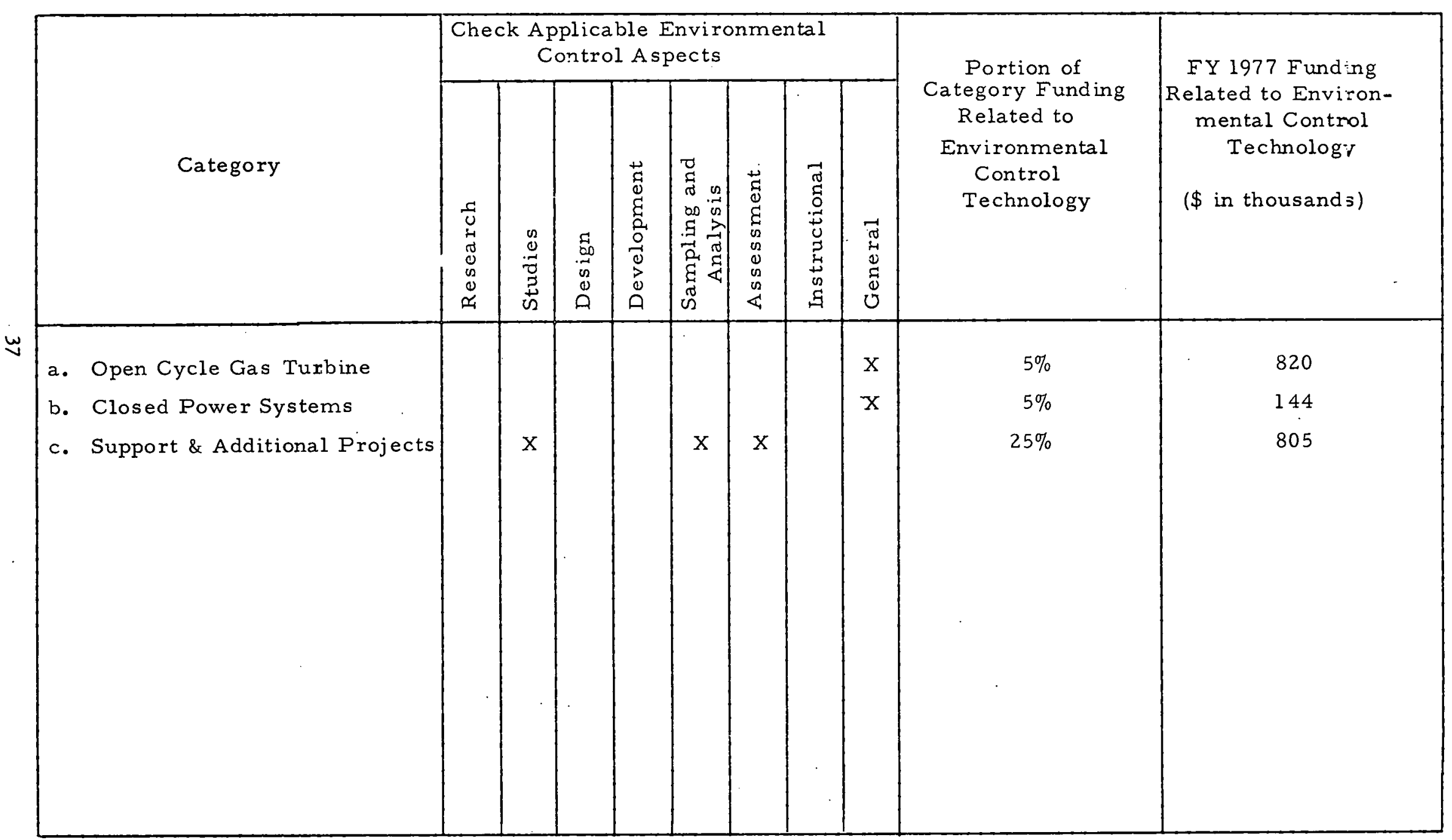


TABLE IV-12

ENVIRONMENTAL CONTROL ASPECTS OF FOSSIL ENERGY PROGRAM

PROGRAM: Coal

SUBPROGRAM: Direct Combusion

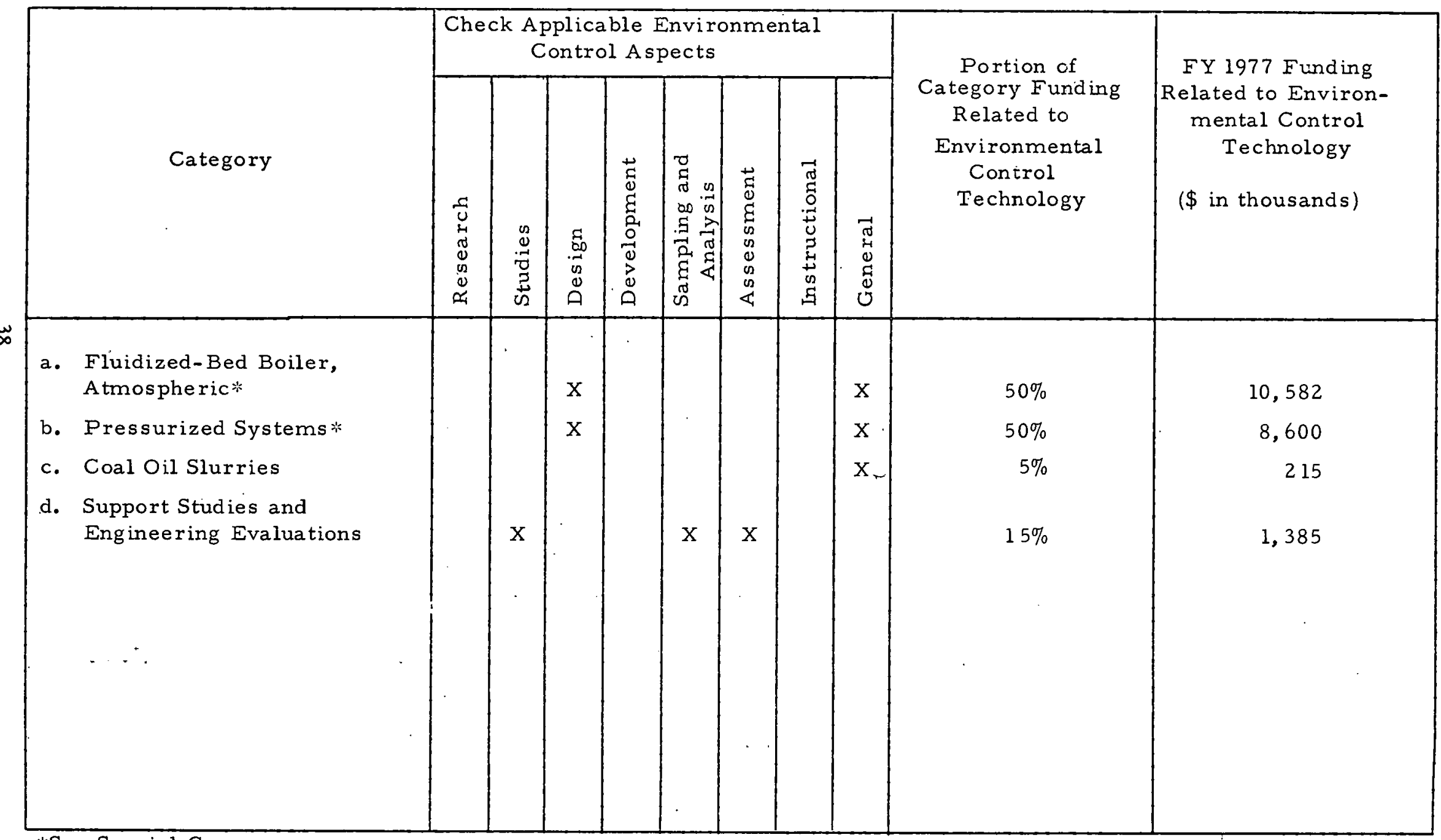

*See Special Cases. 
TABLE IV-13

ENVIRONMENTAL CONTROL ASPECTS OF FOSSIL ENERGY PROGRAM

PROGRAM: Coal

SUBPROGRAM: Advanced Research \& Support Technology

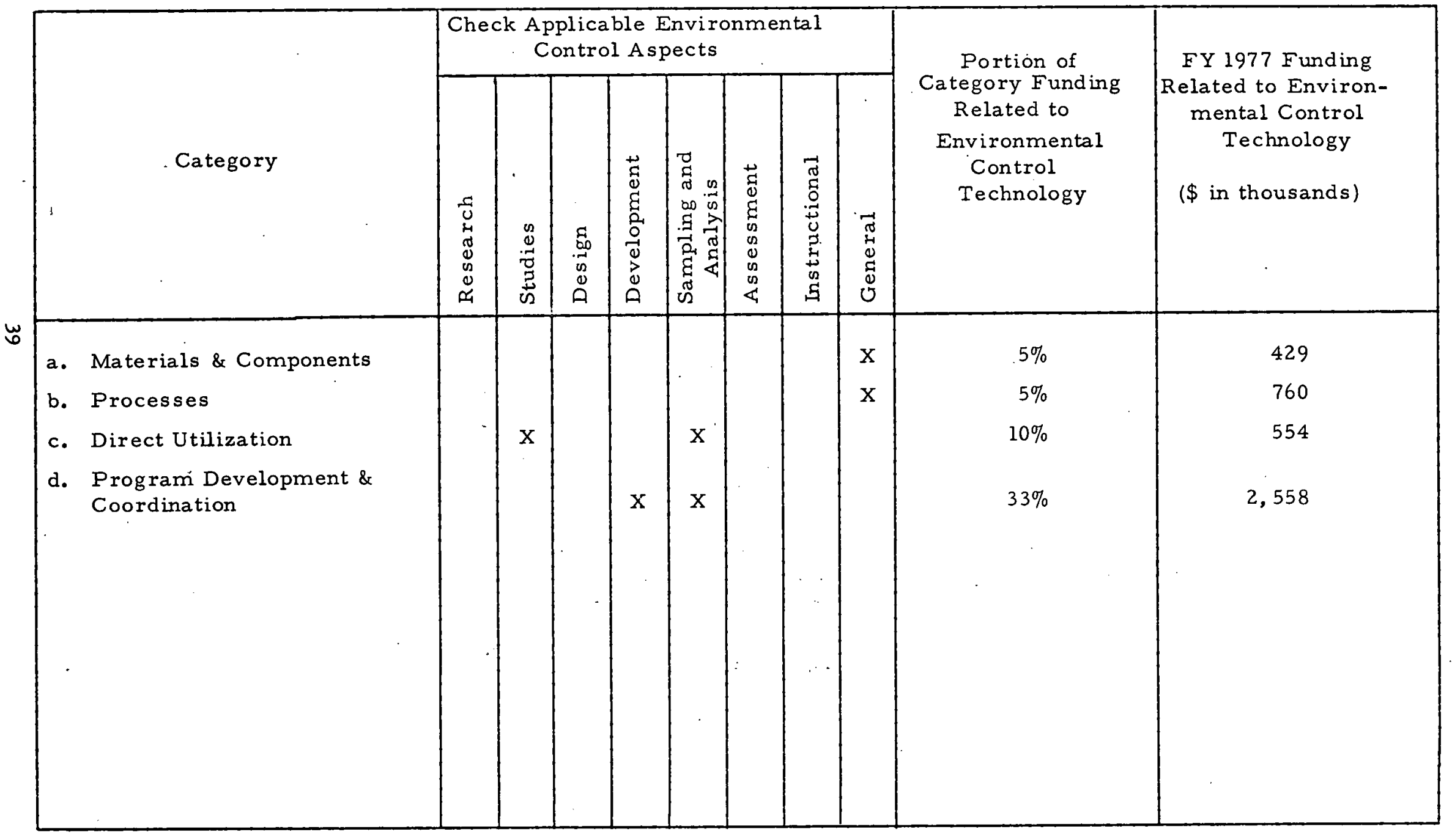


TABLE IV-14

ENVIRONMENTAL CONTROL ASPECTS OF FOSSIL ENERGY PROGRAM

PROGRAM: Coal

SUBPROGRAM: Demonstration Plants

a. Clean Boiler Fuel Demonstration Plant

b. High-Btu Synthetic Pipeline Gas Demonstration Plant

c. Low-Btu Fuel Gas Demionstration Plant

d. Low-Btu Fuel Gas Small Industrial Demonstration Plants

e. Direct Combustion Demonstration Plant*

f. Design \& Technical Support

Check Applicable Environmental Control Aspects

(n)

*See Special Cases (fluidized bed boilers). 
TABLE IV-15

ENVIRONMENTAL CONTROL ASPECTS OF FOSSIL ENERGY PROGRAM

PROGRAM: Coal

SUBPROGRAM: Magnetohydrodynamics

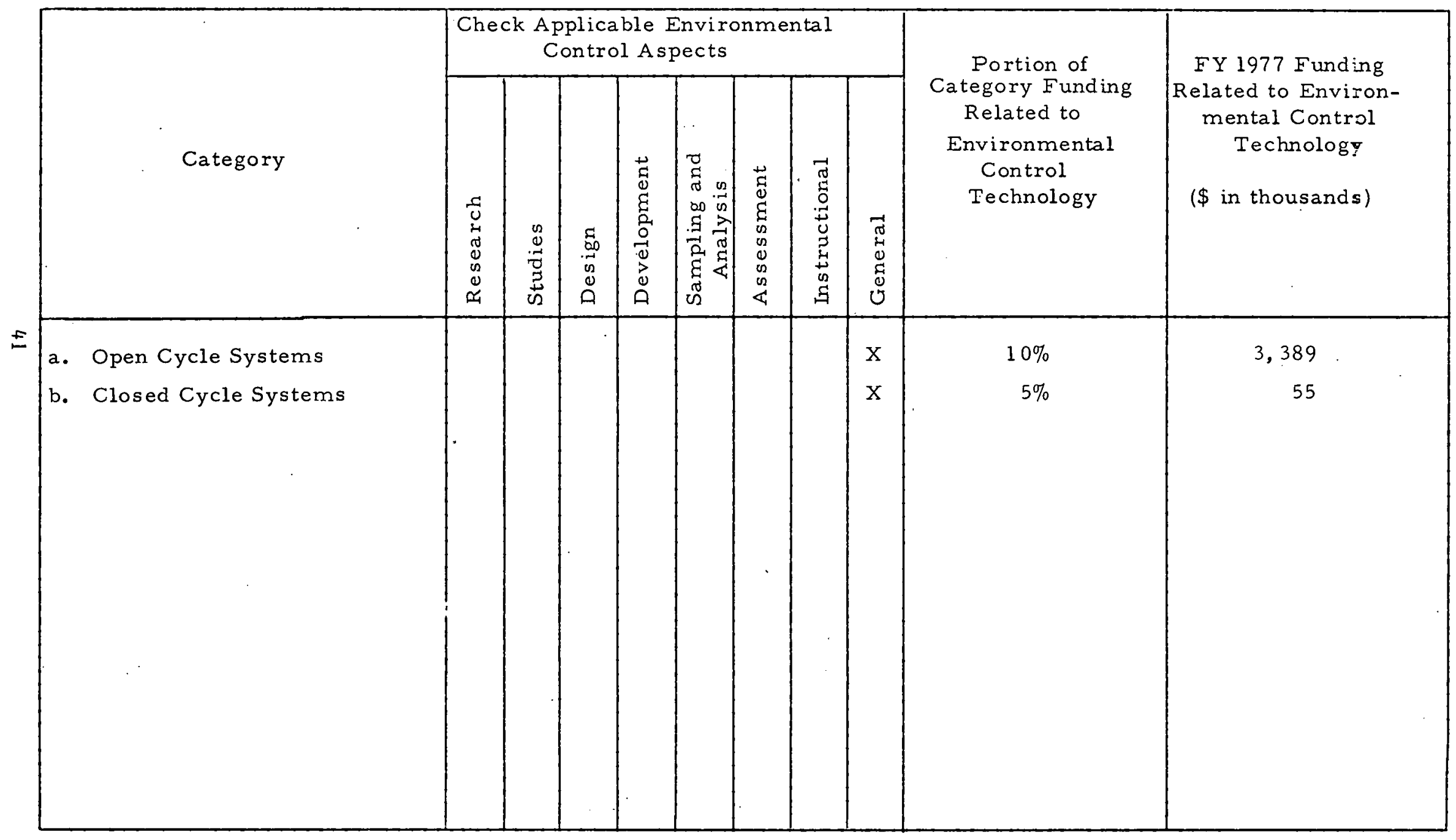


TA BLE IV -16

ENVIRONMENTAL CONTROL ASPECTS OF FOSSIL ENERGY PROGRAM

PROGRAM: Petroleum \& Natural Gas

SUBPROGRAM: Enhanced Oil Recovery

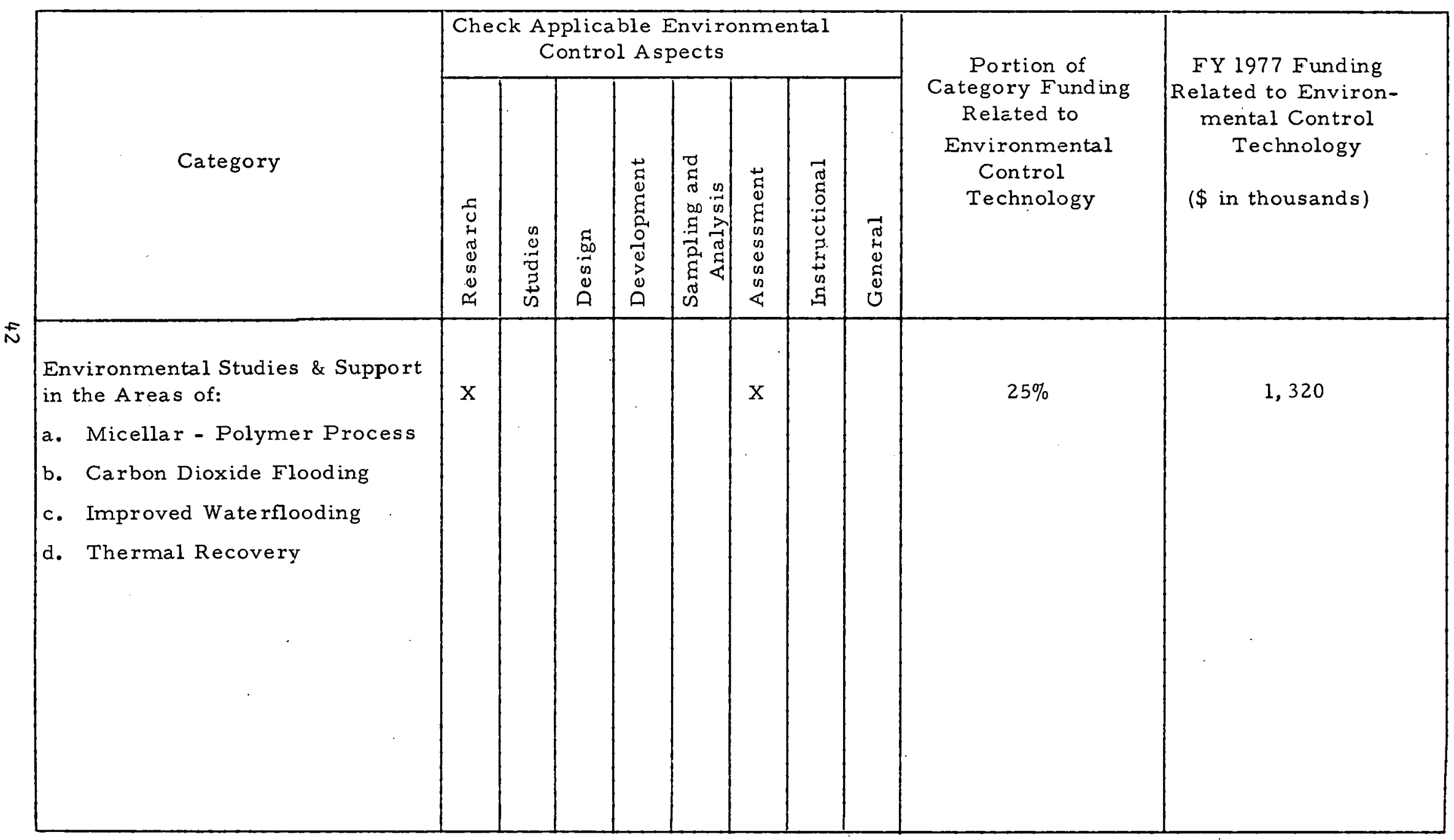


TABLE IV -17

ENVIRONMENTAL CONTROL ASPECTS OF FOSSIL ENERGY PROGRAM

PROGRAM: Petroleum \& Natural Gas

SUBPROGRAM: Enhanced Gas Recovery

$\stackrel{5}{\omega}$

\begin{tabular}{|c|c|c|c|c|c|c|c|c|c|c|}
\hline \multirow[b]{2}{*}{ Category } & \multicolumn{8}{|c|}{$\begin{array}{c}\text { Check Applicable Environmental } \\
\text { Control Aspects }\end{array}$} & \multirow{2}{*}{$\begin{array}{l}\text { Portion of } \\
\text { Category Funding } \\
\text { Related to } \\
\text { Environmental } \\
\text { Control } \\
\text { Technology }\end{array}$} & \multirow{2}{*}{$\begin{array}{l}\text { FY } 1977 \text { Funding } \\
\text { Related to Environ- } \\
\text { mental Control } \\
\text { Technology } \\
\text { (\$ in thousands) }\end{array}$} \\
\hline & $\begin{array}{l}\text { s] } \\
\text { U. } \\
\tilde{d} \\
0 \\
0 \\
0 \\
0\end{array}$ & $\frac{D}{\stackrel{D}{D}}$ & $\begin{array}{l}\mathscr{E} \\
.0 \\
\overrightarrow{0} \\
0 \\
\stackrel{D}{A}\end{array}$ & 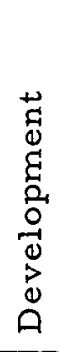 & 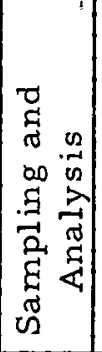 & 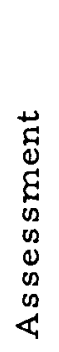 & 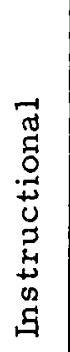 & $\overrightarrow{0}$ & & \\
\hline $\begin{array}{l}\text { Environmental Studies \& Support } \\
\text { in the Areas of: } \\
\text { a. Massive Hydraulic Fracturing } \\
\text { b. Chemical Explosive } \\
\text { Fracturing } \\
\text { c. Deviated Wells } \\
\text { d. Resource Characterization }\end{array}$ & & $\mathrm{x}$ & & & & $\mathrm{x}$ & & & $85 \%$ & $\begin{array}{l}765 \\
.\end{array}$ \\
\hline & & & & & & & & & & \\
\hline
\end{tabular}


TABLE IV-18

ENVIRONMENTAL CONTROL ASPECTS OF FOSSIL ENERGY PROGRAM

PROGRAM: Petroleum \& Natural Gas

SUBPROGRAM: Drilling, Exploration \& Offshore Technology

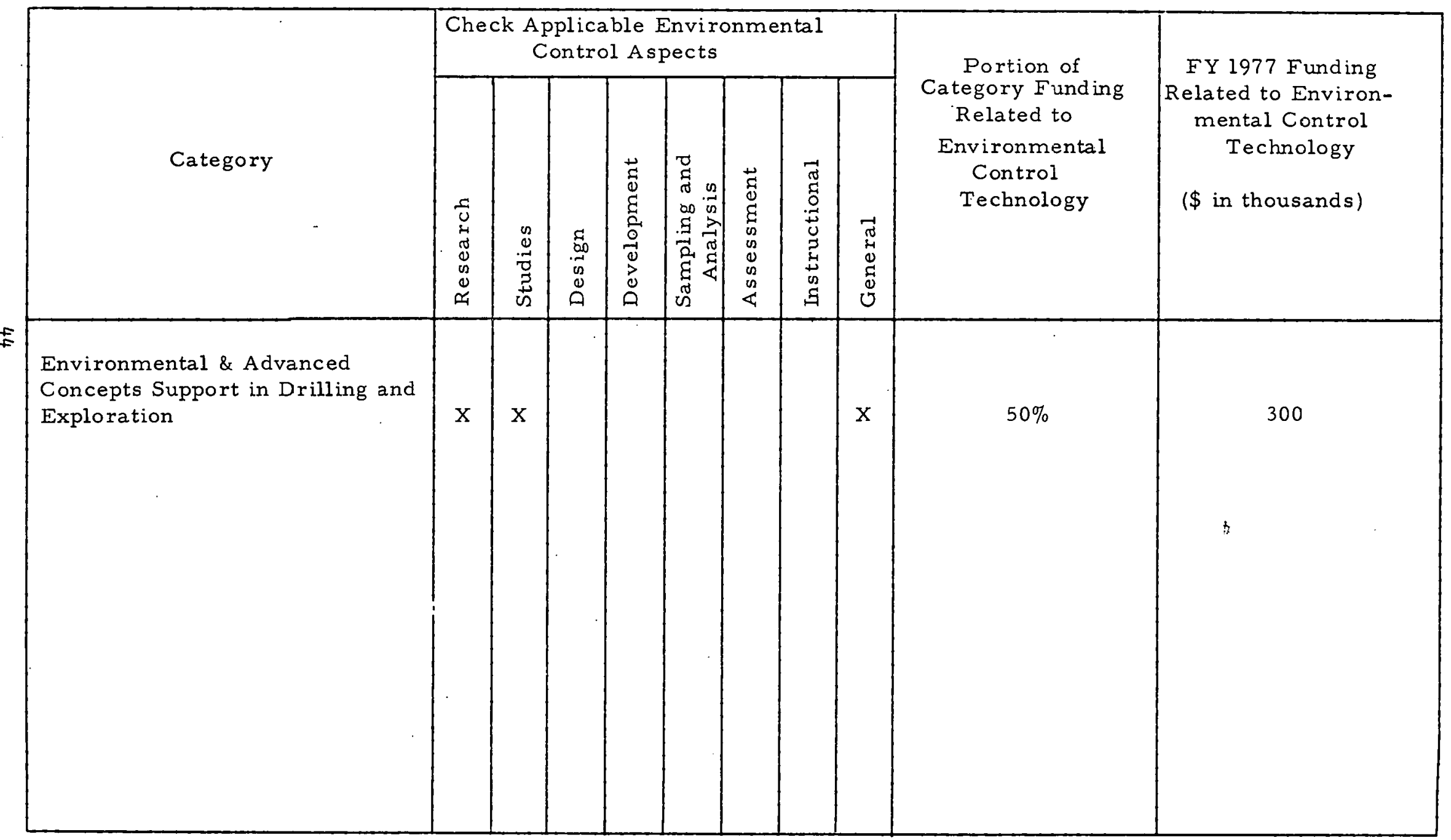


TABLE IV -19

ENVIRONMENTAL CONTROL ASPECTS OF FOSSIL ENERGY PROGRAM

PROGRAM: Petroleum \& Natural Gas

\section{SUBPROGRAN: Processing \& Utilization}

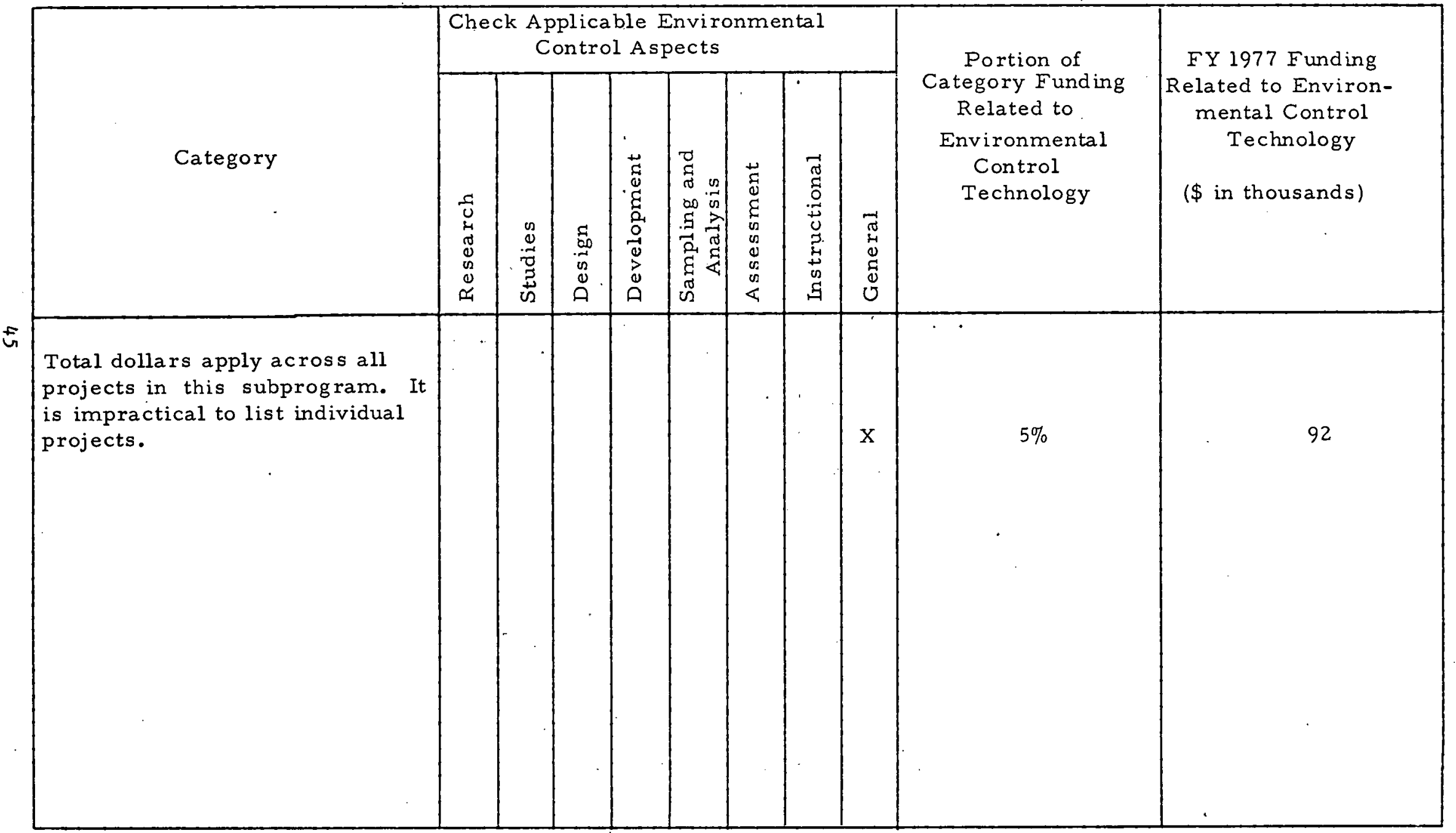


TABLE IV -20

ENVIRONMENTAL CONTROL ASPECTS OF FOSSIL ENERGY PROGRAM

PROGRAM: Oil Shale \& In Situ Technology

SUBPROGRAM: Oil Shale

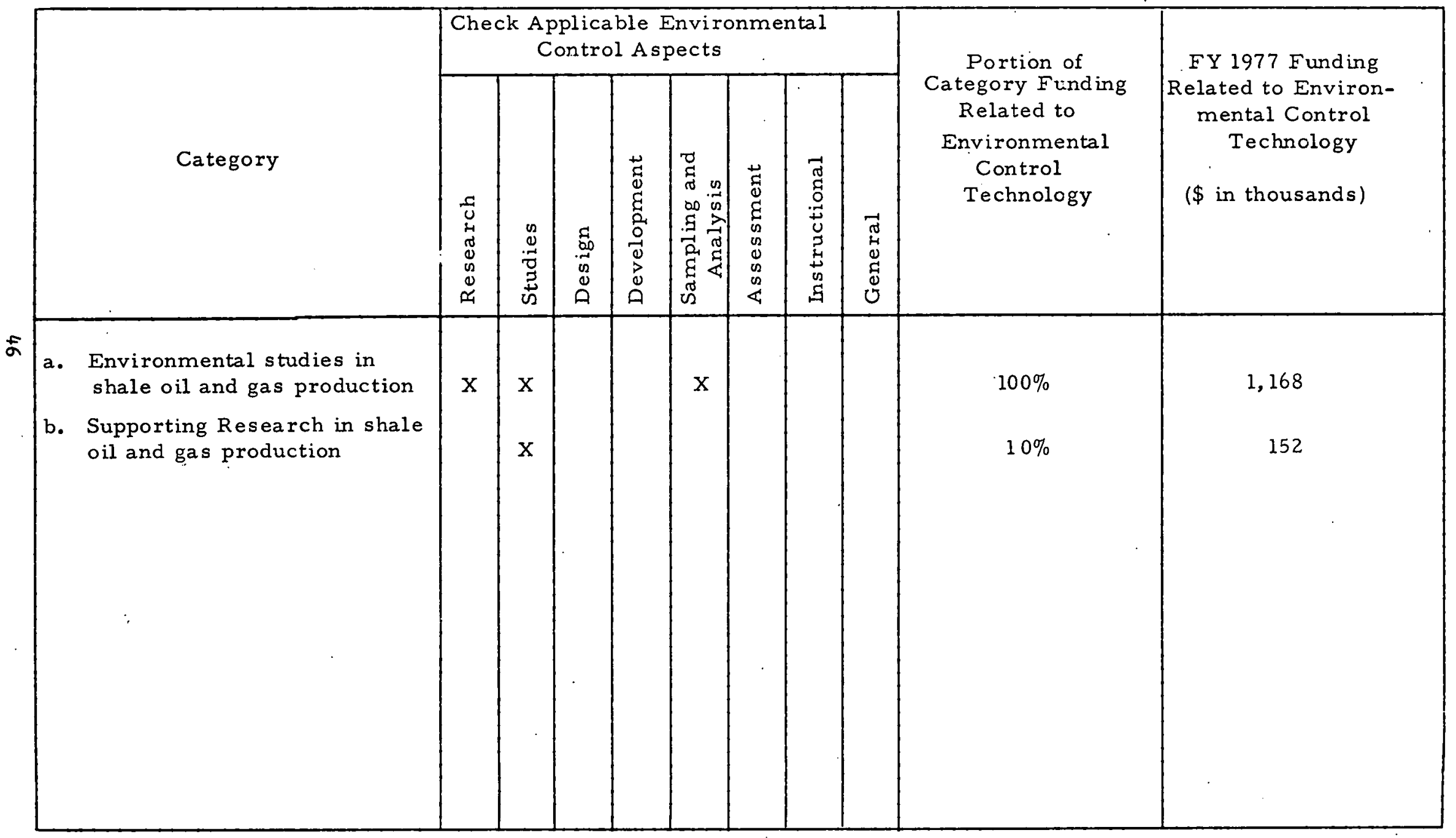


TABLE IV-21

ENVIRONMENTAL CONTROL ASPECTS OF FOSSIL ENERGY PROGRAM

PROGRAM: Oil Shale \& In Situ Technology

SUBPROGRAM: In Situ Coal Gasification

E

Environmental Support in the Areas of:

a. Linked Vertical Wall/ Medium Thick Seams

b. Packed Bed/Thick Seams

c. Longwall Generator/Thin Seams

d. Steeply Dipping Beds 


\section{Nuclear Energy}

The Nuclear Energy (ANE) inputs to this inventory are contained in Tables IV22 through IV-24. The total ANE funding associated with environmental control technology was $\$ 62,195,000$. Waste management, production and reprocessing accounted for 90 percent $(\$ 56,025,000)$ of that total with the major projects being the national waste terminal storage program, commercial High Level Waste (HLW) vitrification, and the radioactive waste demonstration program as shown in Table IV-24.

Reactor development and demonstration environmental control activities are depicted in Table IV-23 and constituted 7 percent of the ANE total related funding $(\$ 4,078,000)$. The largest project, in terms of funding, was in the area of radioactivity control technology. Sodium processing and tritium behavior and control were significant activities with four separate projects. Meteorological studies, jointly funded with the National Oceanic and Atmospheric Administration (NOAA), were also a significant environmental control activity.

Table IV-22 lists the Nuclear Research and Application environmental control activities. These comprised the remaining 3 percent $(\$ 2,092,000)$ of the total ANE funding related to environmental control technology. The projects fall into the categories of effluent control, radioactive material handling, waste heat recycling, diffusion studies, environmental impact assessments, and nuclear fuel behavior safety studies. 
TABLE IV -22

PROJECTS WITH ENVIRONMENTAL CONTROL ASPECTS

ENERGY TECHNOLOGY: Nuclear Energy

PANEL SESSION: Nuclear Research and Applications

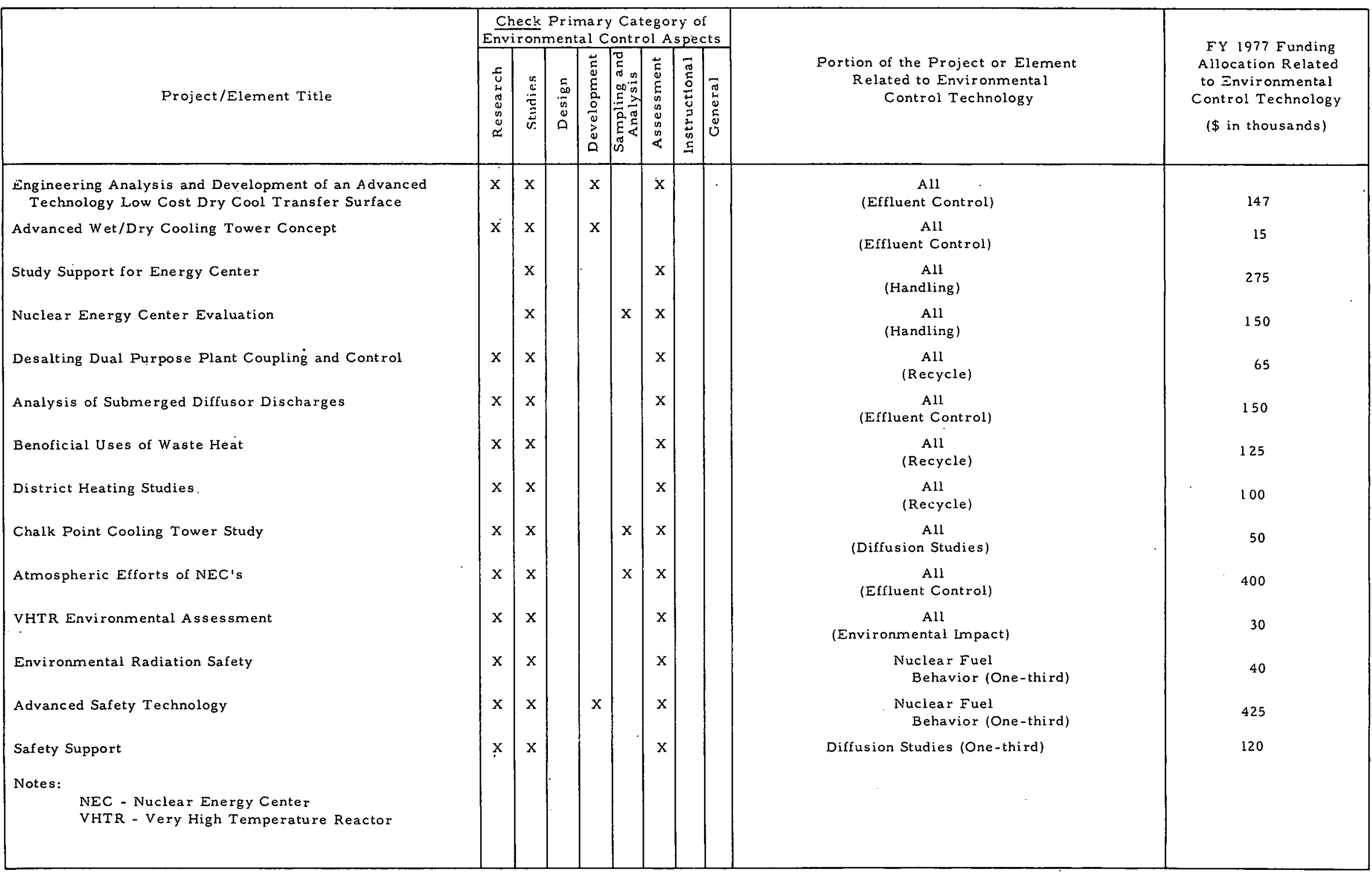


TABLE IV -23

PROJECTS WITH ENVIRONMENTAL CONTROL ASPECTS

ENERGY TECHNOLOGY: Nuclear Energy

DANEL SESSION: Reactor Develooment and Demonstration

\begin{tabular}{|c|c|c|c|c|c|c|c|c|c|c|}
\hline \multirow[b]{2}{*}{ Project/Element Title } & \multicolumn{8}{|c|}{$\begin{array}{l}\text { Check Primary Category of } \\
\text { Environmental Control Aspects }\end{array}$} & \multirow[b]{2}{*}{$\begin{array}{c}\text { Portion of the Project or Element } \\
\text { Related to Environmental } \\
\text { Control Technology }\end{array}$} & \multirow[b]{2}{*}{$\begin{array}{l}\text { FY } 1977 \text { Funding } \\
\text { Allocation Related } \\
\text { to Environmental } \\
\text { Control Technology } \\
\text { ( } \$ \text { in thousands) }\end{array}$} \\
\hline & $\begin{array}{l}5 \\
\text { s. } \\
0 \\
0 \\
0 \\
0 \\
\end{array}$ & 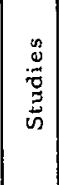 & 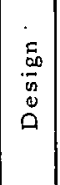 & 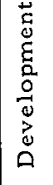 & 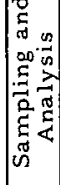 & 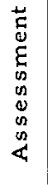 & 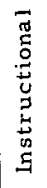 & $\begin{array}{l}\overrightarrow{0} \\
\tilde{\omega} \\
\tilde{\Phi} \\
0\end{array}$ & & \\
\hline Environmental Effects of Advanced LMFBR Fuels & $\mathbf{x}$ & $\mathbf{x}$ & & & $\mathrm{x}$ & $\mathbf{x}$ & & & All & 298 \\
\hline Evaluation of Army Meteorological and Diffusion Data & & $\mathbf{x}$ & & & & & & & All & 50 \\
\hline $\begin{array}{l}\text { Evaluation of Models for Assessment of LMFBR Radio- } \\
\text { activity Releases }\end{array}$ & & $\mathbf{x}$ & & & & $\mathbf{x}$ & & & All & 214 \\
\hline Tritium Control in LMFBR Systems & $\mathrm{x}$ & $\mathbf{x}$ & $\mathbf{x}$ & $\mathrm{x}$ & $\mathrm{x}$ & & & & All & 58 \\
\hline Sodium Processing and Tritium Behavior & $\mathrm{x}$ & $\mathbf{x}$ & $\mathbf{x}$ & & $\mathrm{x}$ & $\mathbf{x}$ & & & All & 380 \\
\hline Meteorological Studies - NOAA* & $\mathrm{x}$ & $\mathbf{x}$ & & & $\mathrm{x}$ & & & & $\begin{array}{c}(\sim 80 \%) \\
\text { Diffusion Studies }\end{array}$ & 200 \\
\hline LMFBR Radiological Dose Assessment Code Improvements & & $\mathbf{x}$ & & & & $\mathrm{x}$ & & & All & 43 \\
\hline Radiation and Effluent Control Technology & $\mathrm{x}$ & $\mathbf{x}$ & $\mathrm{x}$ & $\mathbf{x}$ & $\mathrm{x}$ & $\mathrm{x}$ & & & $\begin{array}{l}(\sim 50 \%) \\
\text { Effluent Control } \\
\text { Techrology Portion }\end{array}$ & 225 \\
\hline FFTF Operations and Training & & & & & $x$ & $\mathbf{x}$ & $\mathrm{x}$ & & $\begin{array}{c}(\sim 4 \%) \\
\text { Environmental Control Equipment Use Training }\end{array}$ & 200 \\
\hline Fuel Failure Monitoring & $\mathrm{x}$ & $\mathrm{x}$ & $x$ & & & $x$ & $x$ & & $\begin{array}{c}(\sim 50 \%) \\
\text { Effluent Control Technology }\end{array}$ & 155 \\
\hline Radioactivity Control Technology & $x$ & $x$ & $x$ & & & $x$ & & & All & 700 \\
\hline Decontamination of LMFBR Components & $\mathbf{x}$ & & $\mathbf{x}$ & & & & & & All & 217 \\
\hline FFTF Test Engineering & & & & & & $x$ & & & $\begin{array}{l}(\sim 5 \%) \\
\text { Preparation of Instructions for Environmental } \\
\text { Control Equipment Use }\end{array}$ & 170 \\
\hline $\begin{array}{l}\text { * Joint Funding with NRC which contributes approxi- } \\
\text { mately funding equal to ERDA's. }\end{array}$ & & & & & & & & & & \\
\hline
\end{tabular}


TABLE IV -23 (Cont)

PROJECTS WITH ENVIRONMENTAL CONTROL ASPECTS

ENERGY TECFNOLOGY: Nuclear EnerğY

PANEL SESSION: Reactor Develooment and Demonstration

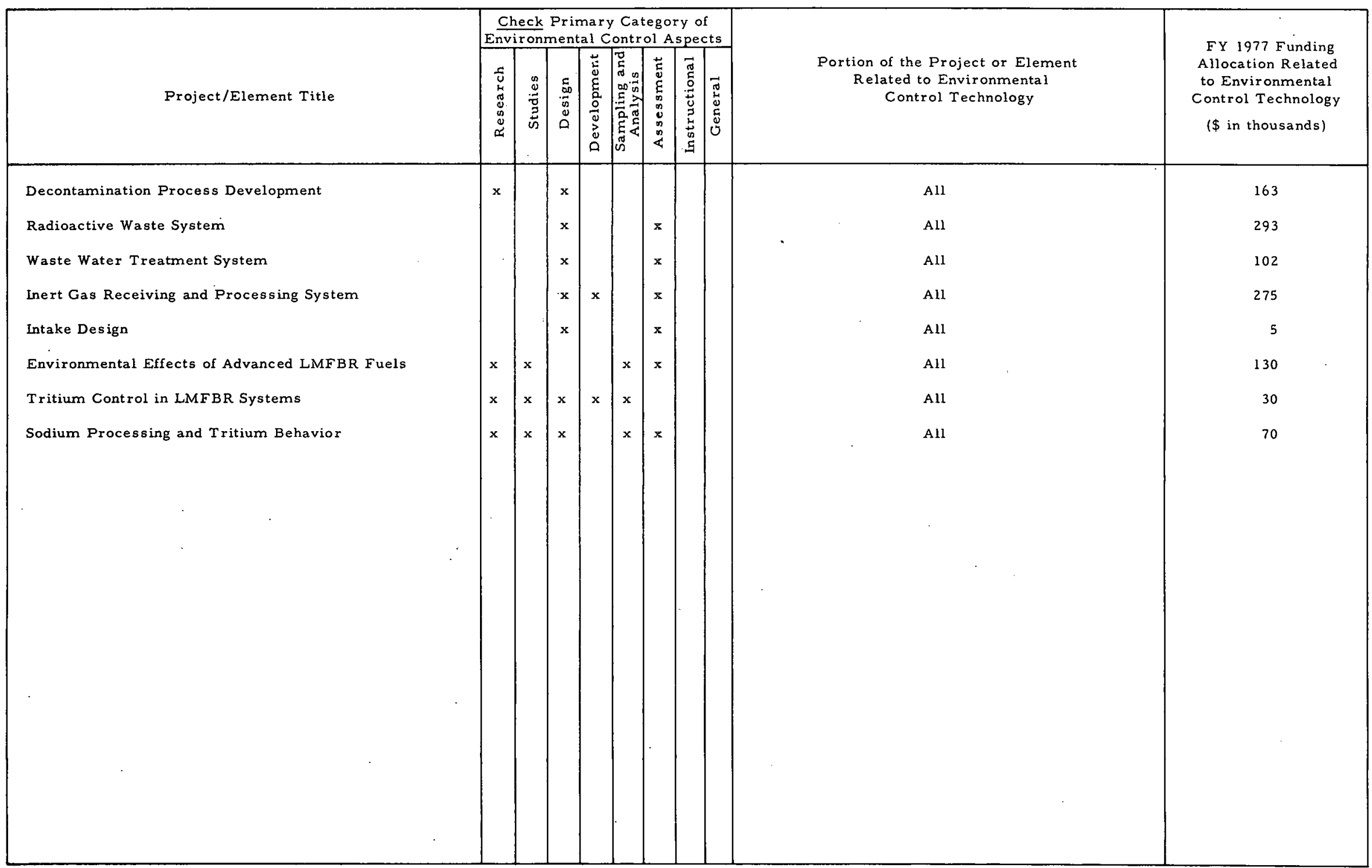


TABLE IV-24

PROJECTS WITH ENVIRONMENTAL CONTROL ASPECTS

ENERGY TECHNOLOGY: Nuclear Energy

PANEL SESSION: Waste Management, Production and

Reprocessing - Commercial Waste Program

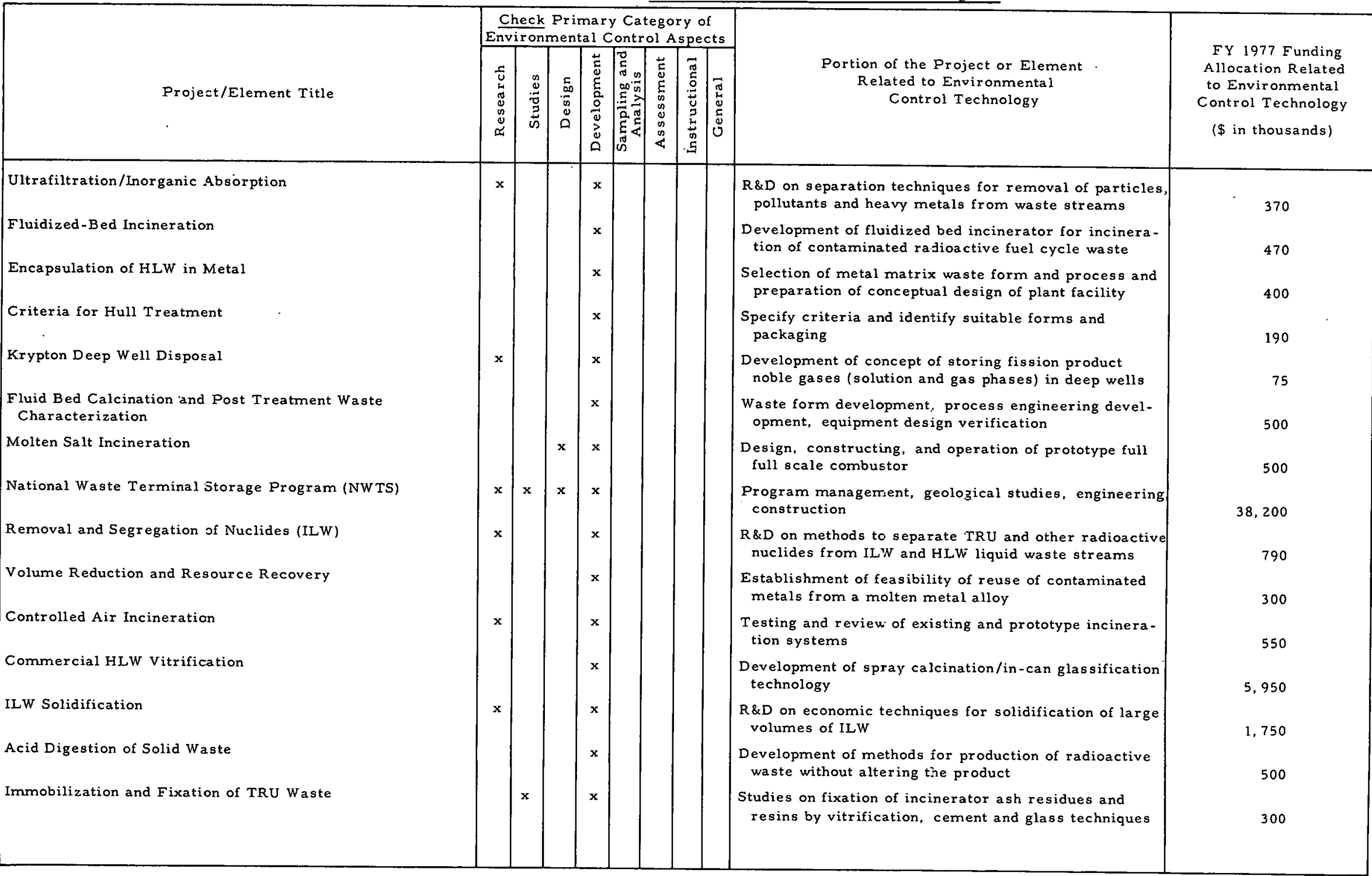


TABLE IV-24 (Cont)

PROJECTS WITH ENVIRONMENTAL CONTROL ASPECTS

ENERGY TECHNOLOGY: Nuclear Energy

PANEL SESSION: Waste Management, Production and

Reprocessing - Commercial Waste Program

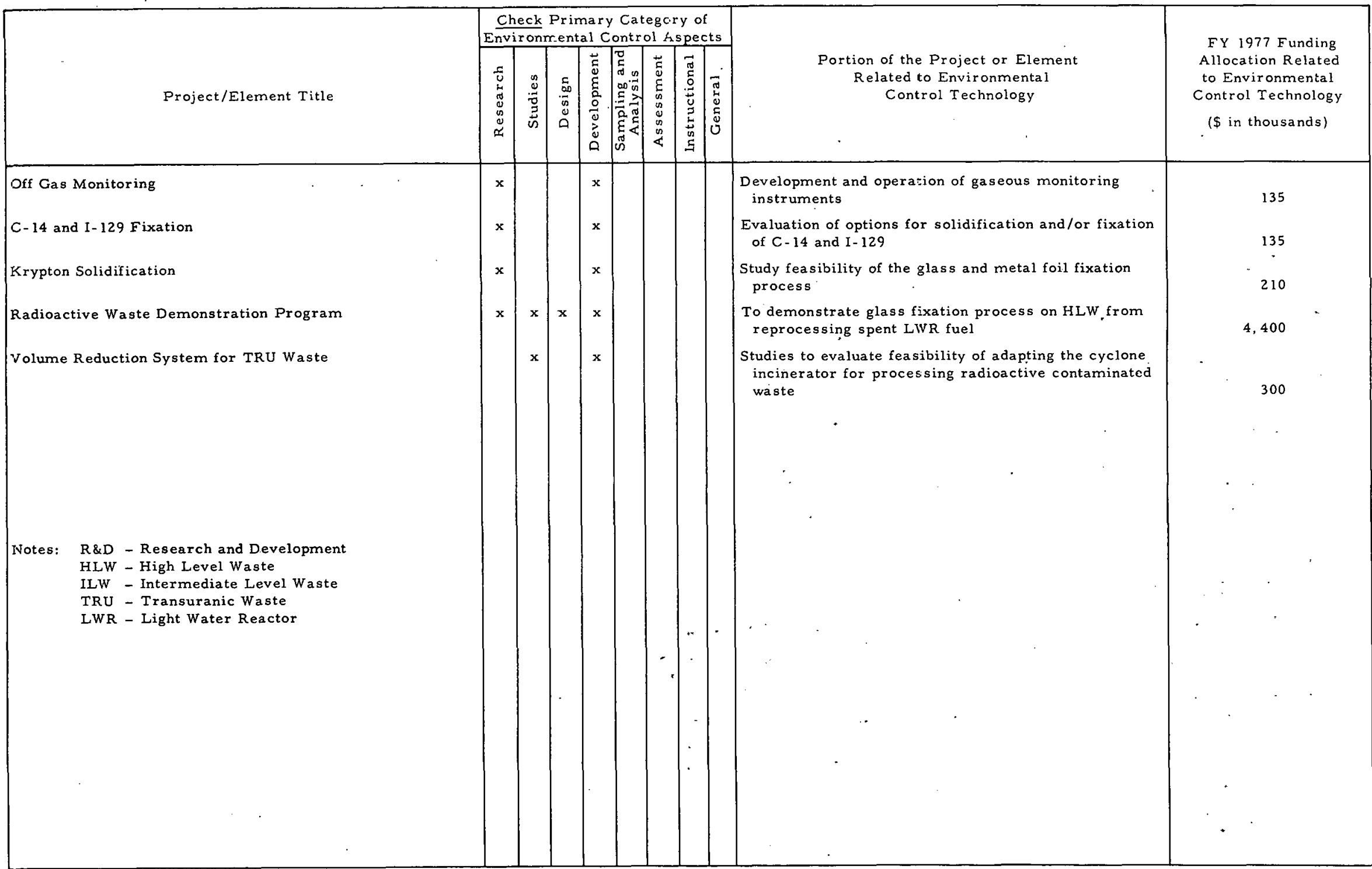




\section{Solar, Geothermal, and Advanced Energy Systems}

The environmental control activities within the Office of the Assistant Administrator for Solar, Geothermal, and Advanced Energy Systems (ASGA) accounted for $\$ 12,337,000$, or 7 percent, of the total ERDA related funding. Of the $\$ 12,337,000$, Geothermal energy development, with $\$ 8,771,000$, comprised the majority ( 71 percent) of the ASGA funding related to environmental control technology. The geothermal projects are shown in Table IV-25. There were over seventy projects listed with the prime emphasis on $\mathrm{H}_{2} \mathrm{~S}$ control, subsidence control, drilling technology, resource exploration and assessment, and hydrothermal technology applications.

The environmental control activities in solar energy development are shown in Table IV-28 and amount to $\$ 2,686,000$ or 22 percent of the ASGA total funding associated with environmental control technology. There were almost 60 projects with partial or total environmental control aspects. They covered all of the subprograms within solar energy which are: heating and cooling; thermal power systems; photovoltaics; and biomass, ocean, and wind systems.

The remaining 7 percent of the total ASGA funding related to environmental control technology was in the categories of magnetic fusion energy and physical research. The former constituted $\$ 780,000$ for the majority of the 7 percent remainder with primary emphasis on tritium containment, control permeation studies, and cleanup systems as denoted in Table IV-26. Physical research activities with $\$ 100,000$ in associated funding are shown in Table IV-27. As noted, there were no separately identified projects. Some design and minor development efforts were associated with environmental control technology in the six line item construction projects listed therein. 
TABLE IV -25

PROJECTS WITH ENVIRONMENTAL CONTROL ASPECTS

ENERGY TECHNOLOGY: Solar, Geothermal, and Advanced Energy Systems

PANEL SESSION: · Geothermal Energy

\begin{tabular}{|c|c|c|c|c|c|c|c|c|c|c|}
\hline \multirow[b]{2}{*}{ Project/Element Title } & \multicolumn{8}{|c|}{$\begin{array}{l}\text { Check Primary Category of } \\
\text { Environmental Control Aspects }\end{array}$} & \multirow[b]{2}{*}{$\begin{array}{c}\text { Portion of the Project or Element } \\
\text { Related to Environmental } \\
\text { Control Technology }\end{array}$} & \multirow[b]{2}{*}{$\begin{array}{l}\text { FY } 1977 \text { Funding } \\
\text { Allocation Related } \\
\text { to Environmental } \\
\text { Control Technology } \\
\text { ( } \$ \text { in thousands) }\end{array}$} \\
\hline & $\begin{array}{l}5 \\
\tilde{J} \\
u \\
\tilde{u} \\
0 \\
0 \\
\simeq\end{array}$ & 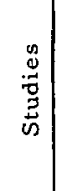 & 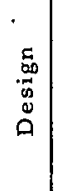 & 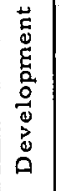 & 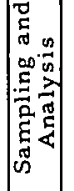 & 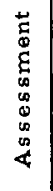 & 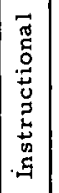 & 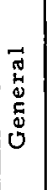 & & \\
\hline Acoustical Drill Monitoring & & $\mathbf{x}$ & $\mathbf{x}$ & & & & & & Environmental Data Monitoring, $15 \%$ & 6.75 \\
\hline Electromagnetic Signal Transmission & & $\mathbf{x}$ & $\mathrm{x}$ & & & & & & $\begin{array}{l}\text { Environmental Data Monitoring, and Transmission, } \\
15 \%\end{array}$ & 14.4 \\
\hline Descaling Techniques & & $\mathbf{x}$ & $\mathbf{x}$ & $\mathbf{x}$ & $\mathrm{x}$ & & & & Determination of Scale Composition, $25 \%$ & 50.0 \\
\hline High Temperature Drilling Fluid & & & & $\mathbf{x}$ & & & & & Development of Nontoxic Drilling Fluids, $15 \%$ & 14.85 \\
\hline Drilling Fluid Instrument (test bed) & $\mathbf{x}$ & $\mathbf{x}$ & $\mathbf{x}$ & & & & & & Development of Nontoxic Drilling Fluids, $25 \%$ & 37.5 \\
\hline Electronic Circuits & & $\mathbf{x}$ & $\mathbf{x}$ & $\mathbf{x}$ & & & & & $\begin{array}{l}\text { Environmental Data Monitoring and Transmission, } \\
10 \%\end{array}$ & 22.0 \\
\hline Computer Model Brine/Mineral System & $\mathbf{x}$ & & & $\mathbf{x}$ & & & & $x$ & Model Fluid Thermodynamics, $75 \%$ & 93.75 \\
\hline Concrete Polymer Composite Material & & & & $\mathbf{x}$ & & & & & Material Development to Increase Well Safety, $50 \%$ & 90.0 \\
\hline High Temperature Polymer Well Cement & $\mathbf{x}$ & & & $\mathbf{x}$ & & & & & Well Material Development to Improve Integrity, $15 \%$ & 39.0 \\
\hline High Temperature Inorganic Cement & $\mathbf{x}$ & & & $\mathbf{x}$ & & & & & Well Material Development to Improve Integrity, $15 \%$ & 25.05 \\
\hline Corrosivity of Brines & $\mathbf{x}$ & & & $\mathbf{x}$ & 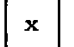 & & & & Determination of Corrosion Rates, $50 \%$ & 112.5 \\
\hline Precipitation and Scaling & $\mathbf{x}$ & & $\mathbf{x}$ & $\mathbf{x}$ & $\mathbf{x}$ & & & & Waste Materials Control, $50 \%$ & 150.0 \\
\hline Iron Base Alloys vs Alternate Materials & $\mathbf{x}$ & & $\mathbf{x}$ & $\mathbf{x}$ & $\mathbf{x}$ & & & & Materials Corrosion Analysis, $10 \%$ & 32.5 \\
\hline Standardized Fluid Analysis Techniques & & $\mathbf{x}$ & $\mathbf{x}$ & $\mathbf{x}$ & $\mathbf{x}$ & $\mathbf{x}$ & & & Fluid Composition Determination, $100 \%$ & 340.0 \\
\hline Downhole Fluid Analysis & $\mathbf{x}$ & $\mathbf{x}$ & $\mathbf{x}$ & $\mathbf{x}$ & $\mathrm{x}$ & $\mathbf{x}$ & & & In-Situ Fluid Composition Analysis, $50 \%$ & 180.0 \\
\hline Silica Precipitation and Brine Management & $\mathbf{x}$ & $\mathrm{x}$ & & & $\mathbf{x}$ & $\mathbf{x}$ & & & Waste Materials Control, $75 \%$ & 75.0 \\
\hline Well Completion Evaluation & & $\mathbf{x}$ & $\mathbf{x}$ & $\mathbf{x}$ & & & & & $\begin{array}{l}\text { Well Completion Safety and Technique Evaluation, } \\
15 \%\end{array}$ & 64.65 \\
\hline In Service Drill Pipe & & & $\mathbf{x}$ & $\mathbf{x}$ & & & & & Test of Pipe Materials for Failure Rates, $25 \%$ & 46.5 \\
\hline Materials Identification. & & $\mathrm{x}$ & $\mathbf{x}$ & & & $\mathbf{x}$ & & & Materials Design Specifications, $50 \%$ & 47.5 \\
\hline Materials for Corrosive Environment & $\mathbf{x}$ & & & $\mathbf{x}$ & & & & & $\begin{array}{l}\text { Bore Hole Material Evaluation and Development, } \\
15 \%\end{array}$ & 7.5 \\
\hline Study of Injection & $\mathbf{x}$ & $\mathbf{x}$ & $\mathbf{x}$ & & & & & & Waste Disposal, Analysis, $50 \%$ & 25.0 \\
\hline Corrosion Fatigue of Geothermal System & & & & $x$ & & & & & Baseline Materials Development, $10 \%$ & 10.0 \\
\hline
\end{tabular}


TABLE IV-25 (Cont)

PROJECTS WITH ENVIRONMENTAL CONTROL ASPECTS

ENERGY TECHNOLOGY: Solar, Geothermal, and Advanced Enezgy Systems

PANEL SESSION: Geothermal Energy

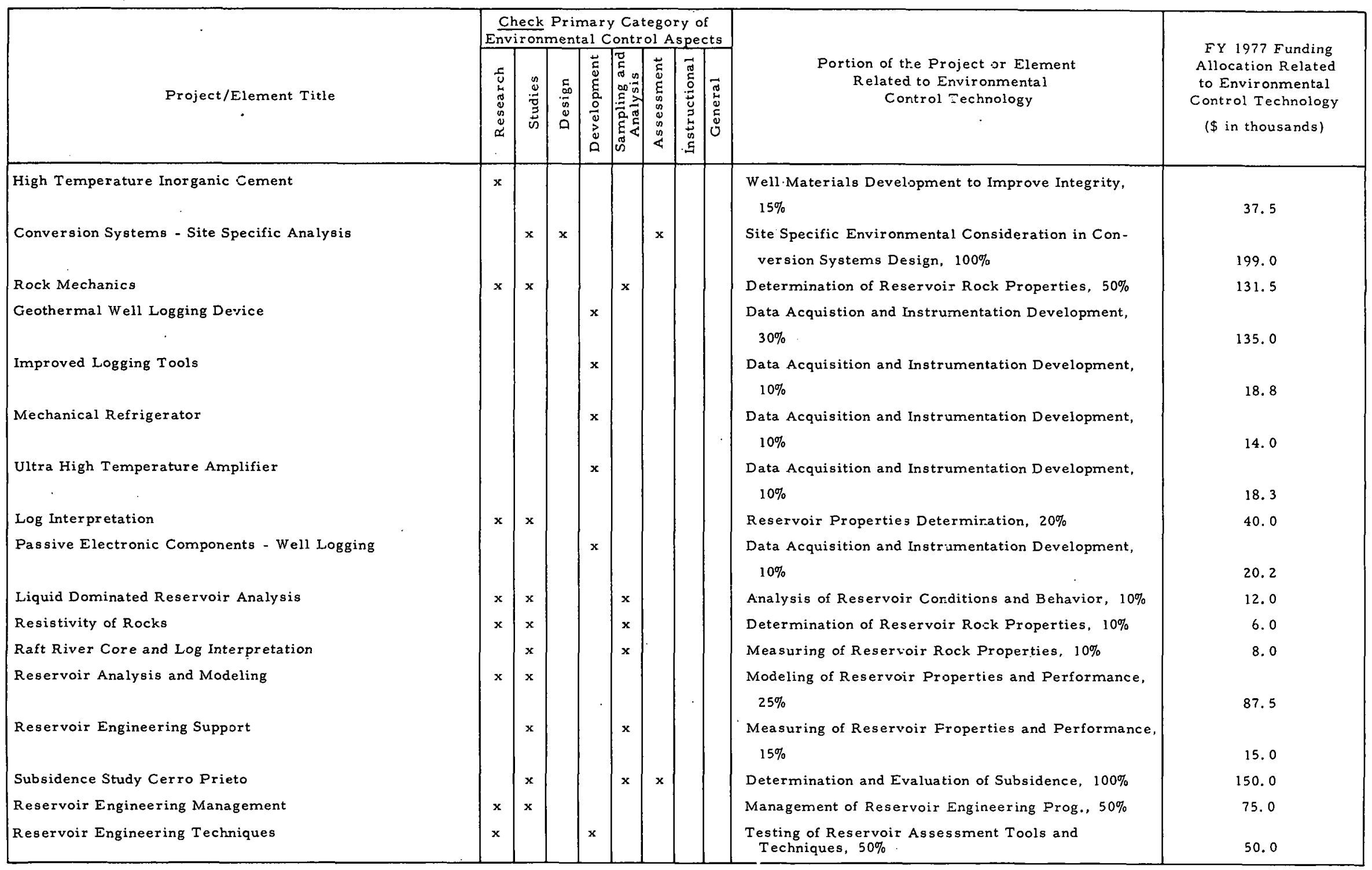


TABLE IV-25 (Cont)

PROJECSS WITH ENVIRCNMENTAL CONTROL ASPECTS

ENERGY TECHNOLOGY: Solar, Geothermal, and Advanced Energy Systems

PANEL SESSION: Geothermal Energy

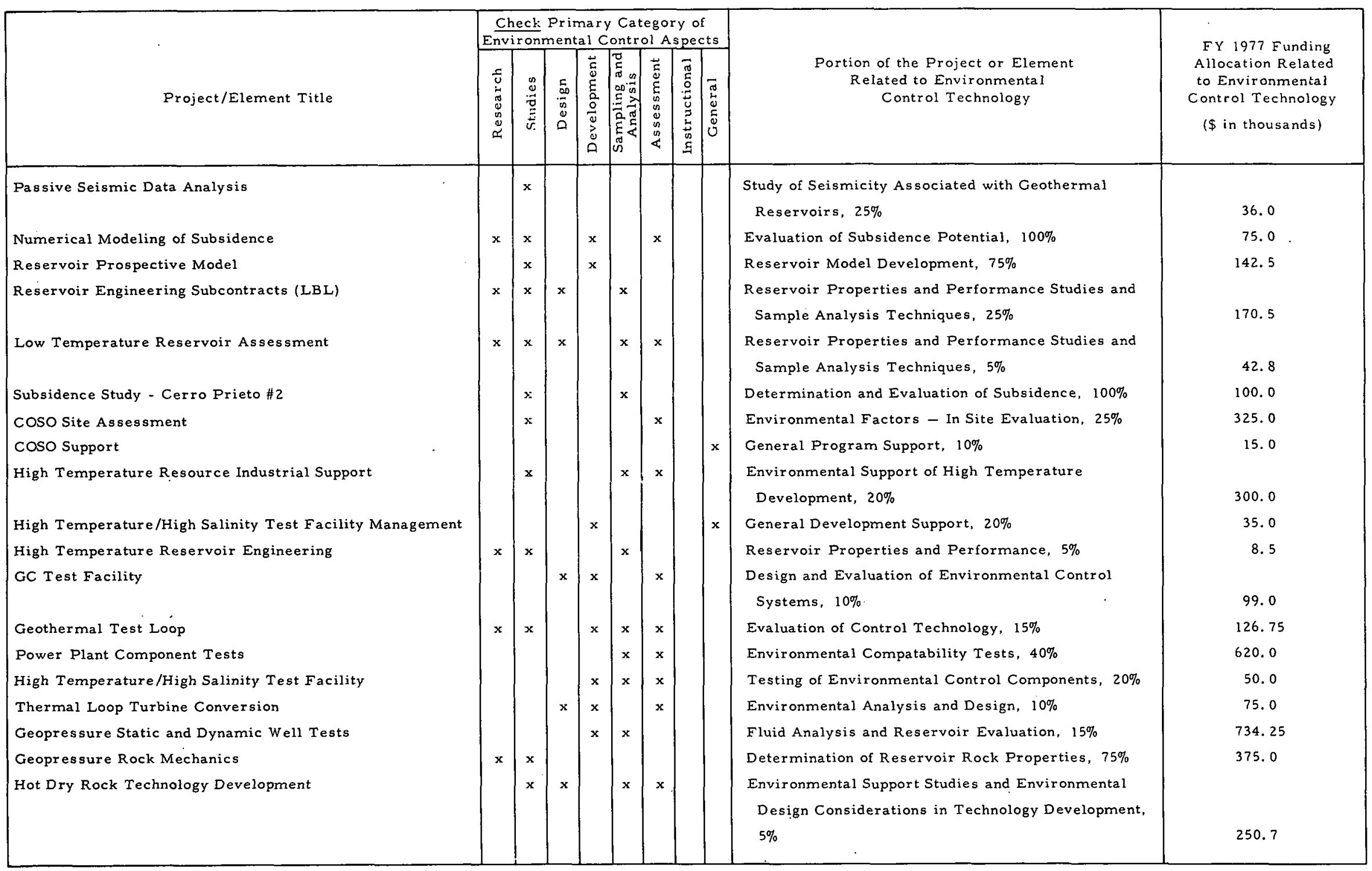


TABLE IV-25 (Cont)

PROJEC'TS WITH ENVIRONMENTAL CONTROL ASFECTS

ENERGY TECHNOLOGY: Solar, Geothermal, and Advanced Energy Systems

PANEL SESSION: Geothermal Energy

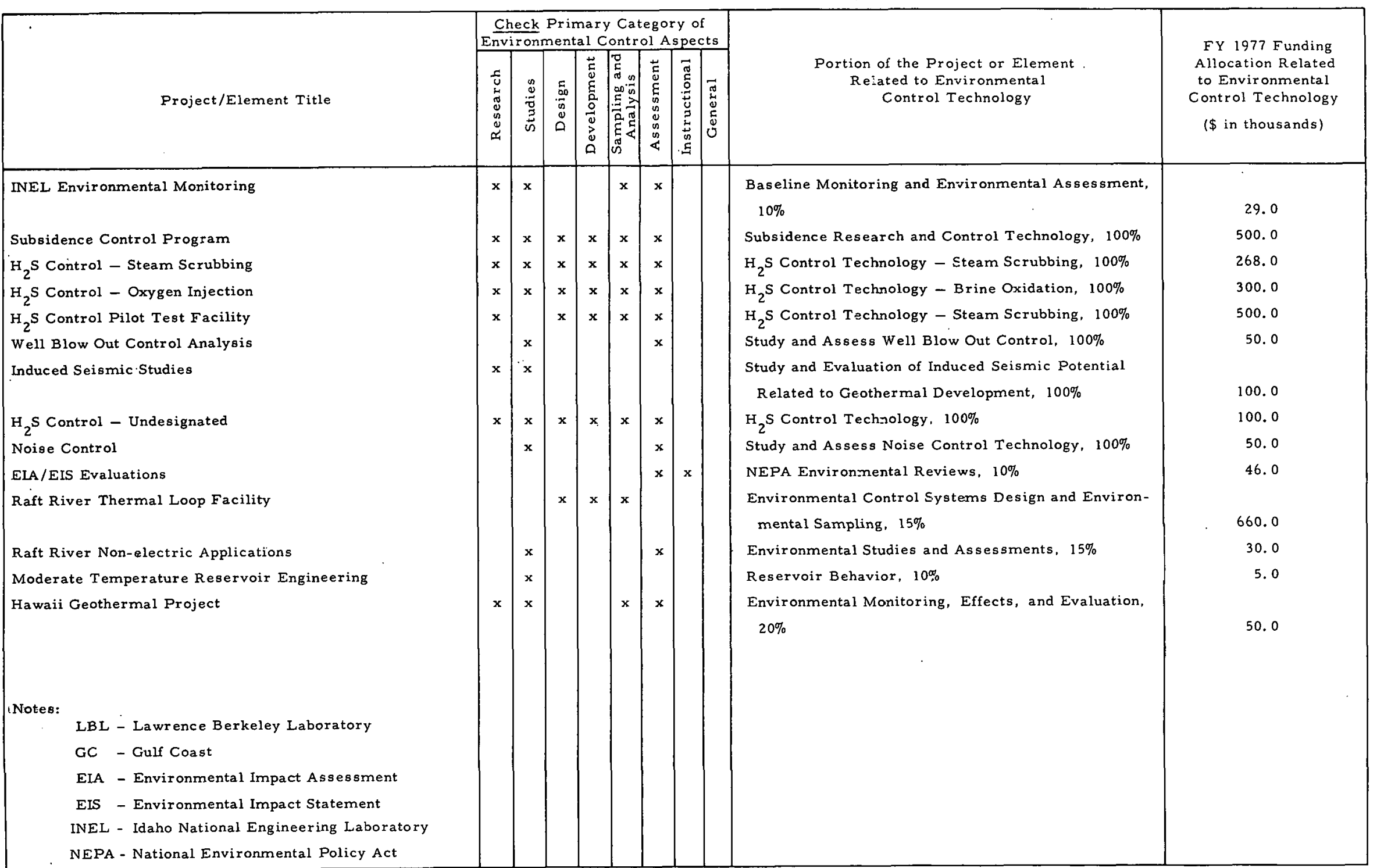


TABLE IV -26

PROJECTS WITH ENVIRONMENTAL CONTROL ASPECTS

ENERGY TECHNOLOGY: Solar, Geothermal, and Advanced Energy Systems

PANEL SESSION: Magnetic Fusion Energy

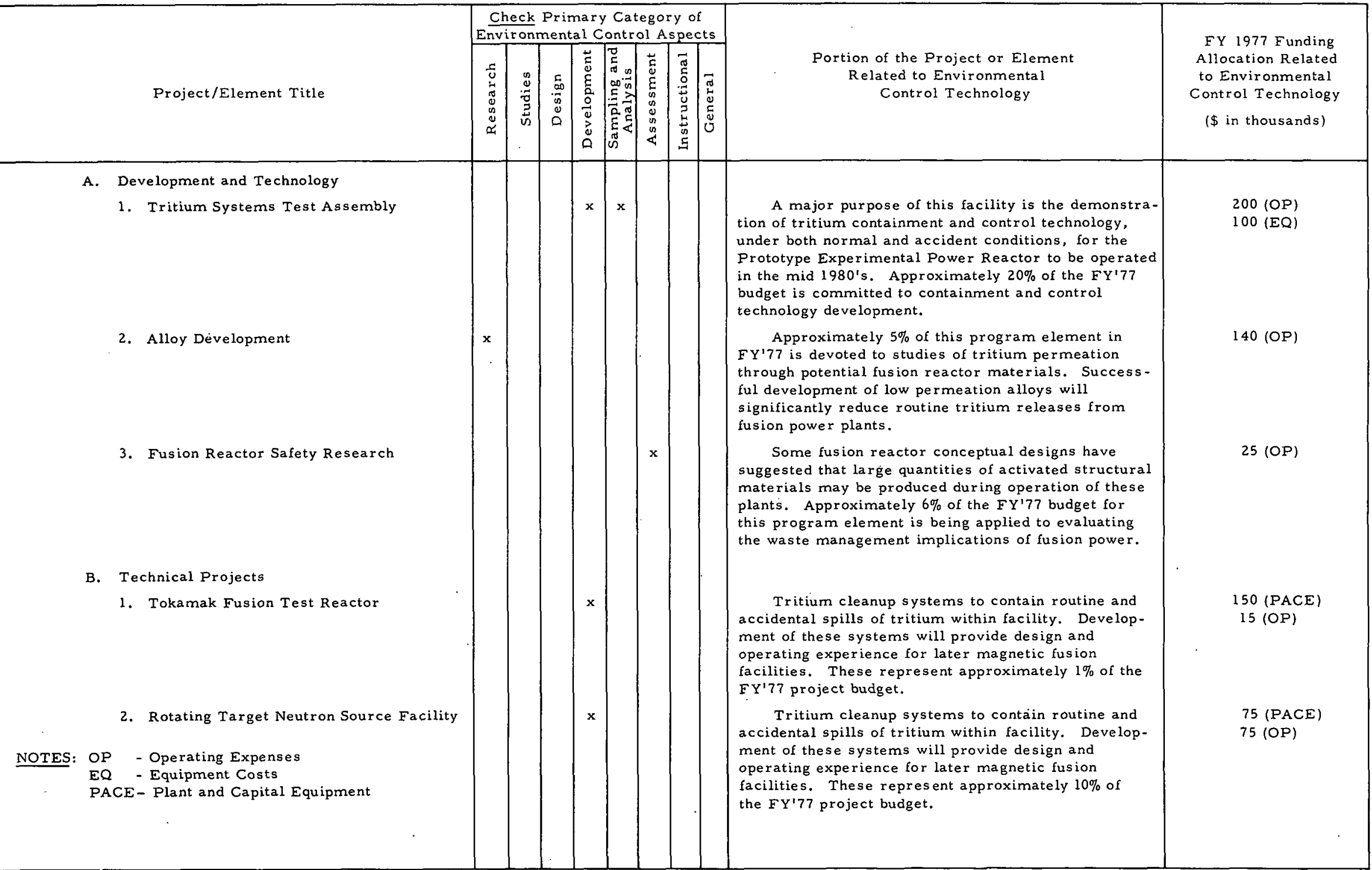


TABLE IV - 27

PROJECTS WITH ENVIRONMENTAL CONTROL ASPECTS

ENERGY TECHNOLOGY: Solar, Geothermal and Advanced Energy Systems

PANEL SESSION: Physical Research

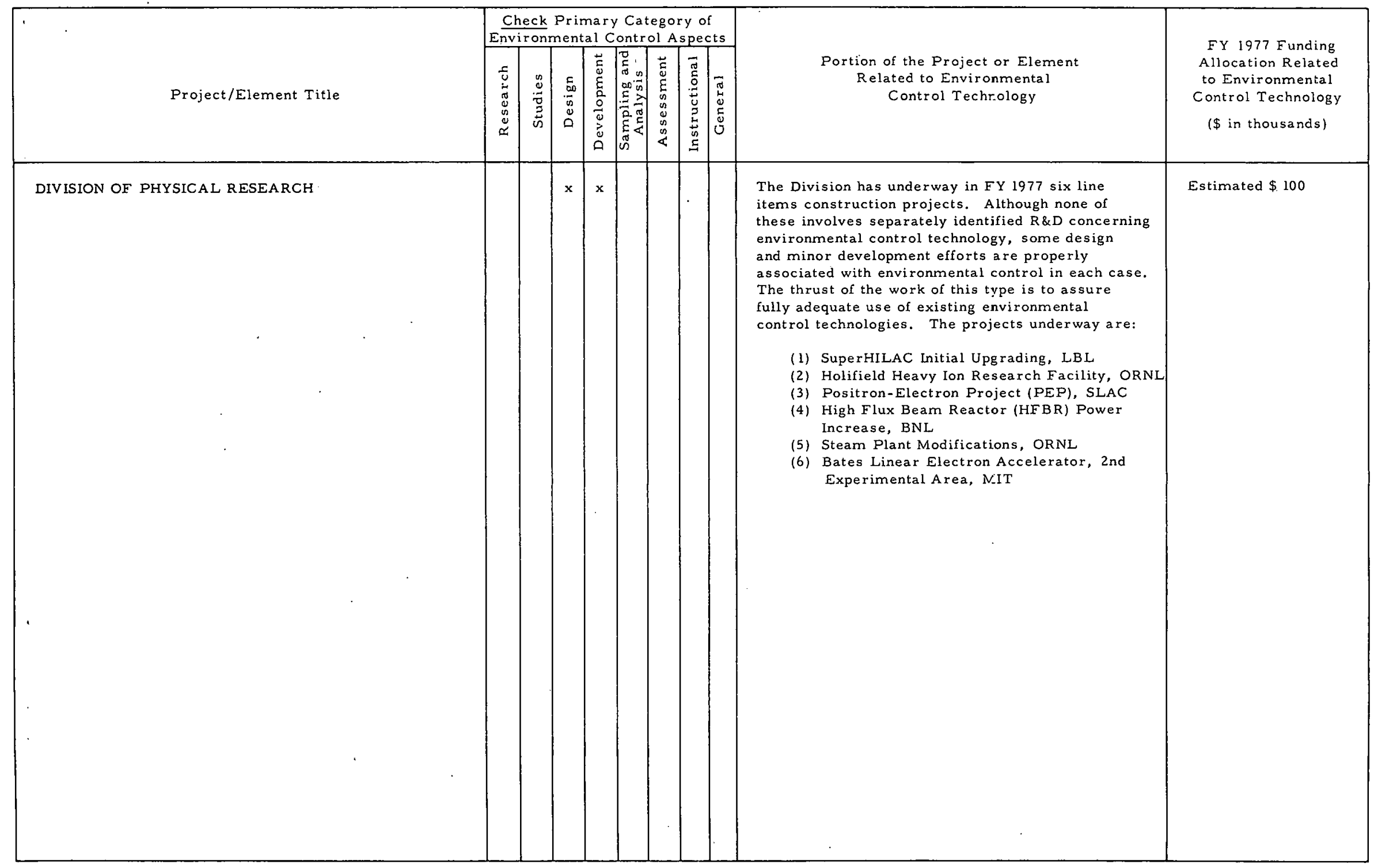


TABLE IV -28

PROJECTS WITH ENVIRONMENTAL CONTROL ASPECTS

ENERGY TECHNOLOGY: Solar, Geothermal, \& Advanced Energy Systems

PANEL SESSION: Solar Energy

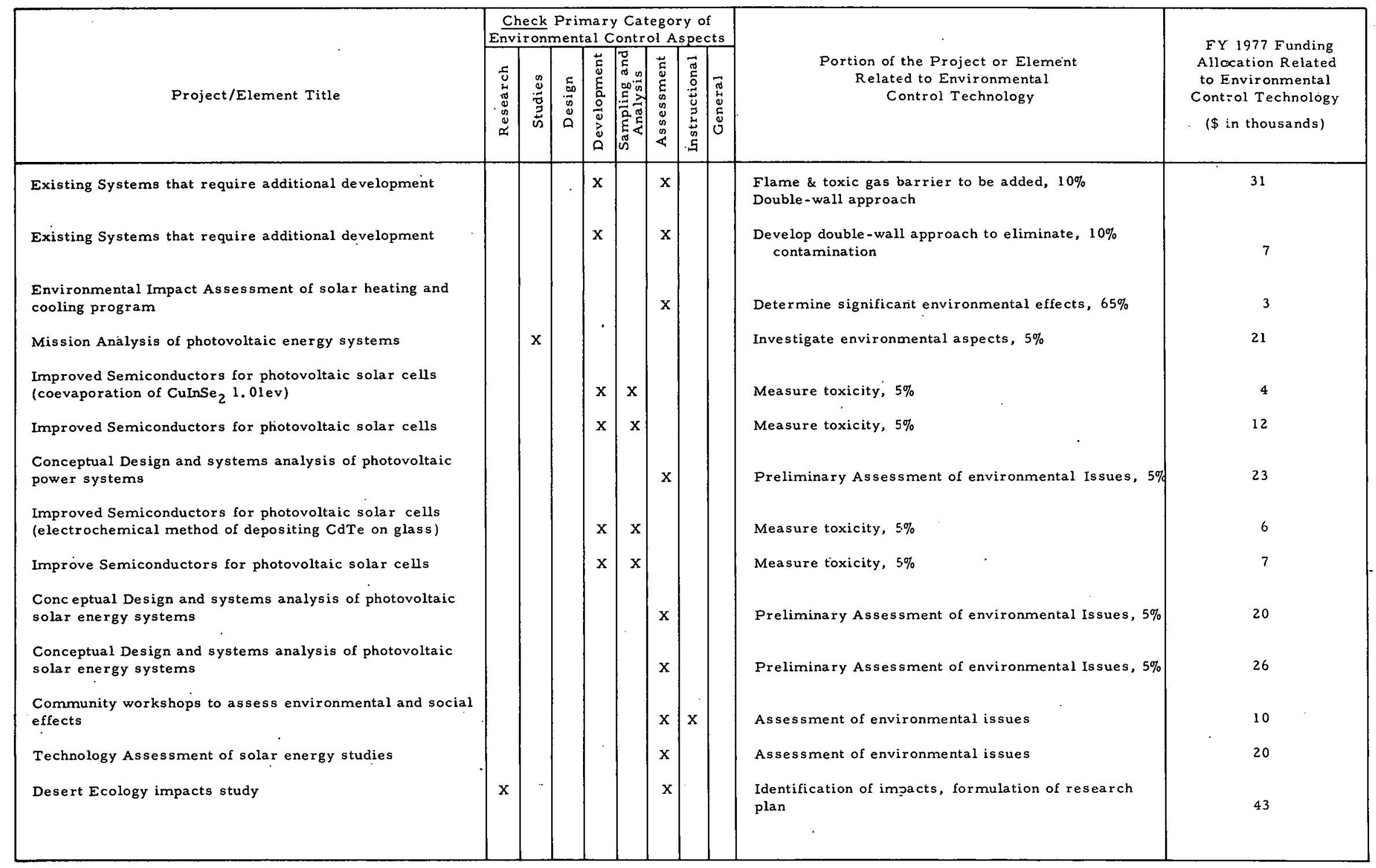


TTABLE IV - 28 (Cont)

\section{PROJECTS WITH ENVIRONMENTAL CONTROL ASPECTS}

ENERGY TECHNOLOGY: Solar, Geothermal, \& Advanced Energy Systems

PANEL SESSION: Solar Energy

\begin{tabular}{|c|c|c|c|c|c|c|c|c|c|c|}
\hline \multirow[b]{2}{*}{ Project/Element Title } & \multicolumn{8}{|c|}{$\begin{array}{l}\text { Check Primary Category of } \\
\text { Environmental Control Aspects }\end{array}$} & \multirow[b]{2}{*}{$\begin{array}{c}\text { Portion of the Project or Element } \\
\text { Related to Environmental } \\
\text { Control Technology }\end{array}$} & \multirow[b]{2}{*}{$\begin{array}{l}\text { FY } 1977 \text { Funding } \\
\text { Allocation Related } \\
\text { to Environmental } \\
\text { Control Technology } \\
\text { ( } \$ \text { in thousands) }\end{array}$} \\
\hline & 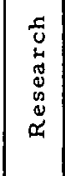 & 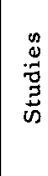 & 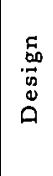 & 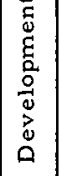 & 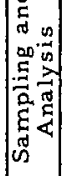 & 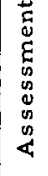 & 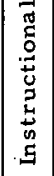 & 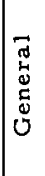 & & \\
\hline $\begin{array}{l}\text { Environmental Impact Assessments - photovoltaic power } \\
\text { plant }\end{array}$ & & & & & & $\mathrm{x}$ & & & Assessment of potential environmental effects & 12 \\
\hline Solar Preliminary Technology Assessment & & & & & & $\mathrm{x}$ & & & Assessment of environmental issues & 25 \\
\hline SPS Environmental Analysis/Integration & & & & & & $\mathrm{x}$ & & & Assessment of environmentel effects & 35 \\
\hline Environmental Development Plans for eight technologies & & & & & & $\mathrm{x}$ & & & $\begin{array}{l}\text { Identification of Environmental research, assess- } \\
\text { ments, etc., } 50 \%\end{array}$ & 55 \\
\hline NBS Standards Activities & & & & $\mathrm{X}$ & & · & & & Materials, safety, etc., standards for SHACOB, $15 \%$ & 263 \\
\hline Standards \& Test Procedures & & & & $\mathrm{x}$ & & & & & $\begin{array}{l}\text { Procedures \& Standards for SHACOB Test Facilities, } \\
2 \%\end{array}$ & 5 \\
\hline Direct Contact Liquid/Liquid, Heat Exchanger & & & & $\mathrm{x}$ & & & & & $\begin{array}{l}\text { Develop a liquid to liquid heat exchanger toxicologial } \\
\text { studies, } 50 \%\end{array}$ & 10 \\
\hline $\begin{array}{l}\text { Marine Biota Impact Assessment for Ocean Thermal } \\
\text { Energy Conversion(OTEC)(RFP\#EG-77-R-06-1032) }\end{array}$ & $\mathrm{x}$ & & $\mathrm{x}$ & & & $\mathrm{x}$ & & & Plan for mitigational control, $75 \%$ & 75 \\
\hline $\begin{array}{l}\text { Environmental Impact Assessments (EIA.s) of ocean test } \\
\text { platforms for Ocean Thermal Energy Conversion (OTEC) } \\
\text { (RFP \#EG-77-R-06-1033) }\end{array}$ & & & & & & $\mathrm{x}$ & & & $\begin{array}{l}\text { Identification of control measures on OTEC test } \\
\text { platforms, } 50 \%\end{array}$ & 25 \\
\hline OTEC Program Management Support & & & $\mathrm{x}$ & $\mathrm{x}$ & & & & $\mathrm{x}$ & Physical oceanographic impact control for OTEC, $50 \%$ & 30 \\
\hline Experimental Study Flow Problems related to OTEC & $\mathrm{x}$ & $\mathrm{x}$ & $\mathrm{x}$ & & & & & & Physical oceanographic impact control for OTEC, $25 \%$ & 12 \\
\hline OTEC - Program Management Support & & & $\mathrm{x}$ & $\mathrm{x}$ & & & & $x$ & Marine Biota impact control for OTEC, $50 \%$ & 15 \\
\hline OTEC Research Contracts to Review & $\mathrm{x}$ & $\mathrm{x}$ & $\mathrm{x}$ & & & & & & Physical oceanographic impact control for OTEC, $50 \%$ & 3 \\
\hline $\begin{array}{l}\text { Environmental Impact Assessment for WECS candidate } \\
\text { sites }\end{array}$ & & & & & & $\mathrm{x}$ & & & Identify environmental issues, $50 \%$ & 10 \\
\hline Biomass to Methane & $\mathrm{x}$ & & & & & & & & $\begin{array}{l}\text { Identification of products \& by products requiring } \\
\text { environmental analysis }\end{array}$ & 80 \\
\hline
\end{tabular}


TABLE IV - 28 (Cont)

PROJECTS WITH ENVIRONMENTAL CONTROL ASPECTS

ENERGY TECHNOLOGY: Solar, Geothermal, \& Advanced Energy Systems

PANEL SESSION: Solar Energy

\begin{tabular}{|c|c|c|c|c|c|c|c|c|c|c|}
\hline \multirow[b]{2}{*}{ Project/Element Title } & \multicolumn{8}{|c|}{$\begin{array}{l}\text { Check Primary Category of } \\
\text { Envircnmental Control Aspects }\end{array}$} & \multirow[b]{2}{*}{$\begin{array}{c}\text { Portion of the Project or Element } \\
\text { Related to Environmental } \\
\text { Control Technology }\end{array}$} & \multirow[b]{2}{*}{$\begin{array}{l}F^{y} 1977 \text { Funding } \\
\text { Allocation Related } \\
\text { to Environmental } \\
\text { Conirol Technology } \\
\text { ( } \$ \text { in thousands) }\end{array}$} \\
\hline & 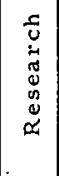 & 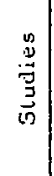 & 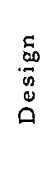 & 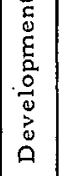 & 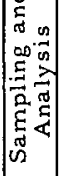 & 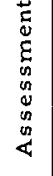 & 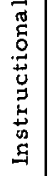 & 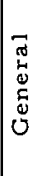 & & \\
\hline Anoerobic Digestion & $\mathrm{x}$ & & & & & & & & $\begin{array}{l}\text { Identification of products \& by products requiring } \\
\text { environmental analysis }\end{array}$ & 50 \\
\hline Feedlot Energy & $\mathrm{x}$ & & & $x$ & & & & & $\begin{array}{l}\text { Idenfification of products \& by products requiring } \\
\text { environmental analysis }\end{array}$ & 20 \\
\hline Livestock Manures and crop residues & $\mathrm{x}$ & & & & & & & & $\begin{array}{l}\text { Identification of products \& by products requiring } \\
\text { environmental a nalysis }\end{array}$ & 10 \\
\hline Recovered Fuel Gas From Residue & $\mathrm{x}$ & & & & & & & & $\begin{array}{l}\text { Identification of products \& by products requiring } \\
\text { environmental analysis }\end{array}$ & 10 \\
\hline Operation Digestion - 350 cattle unit & $\mathrm{x}$ & & & $\mathrm{x}$ & & & & & $\begin{array}{l}\text { Identification of products \& by products requiring } \\
\text { environmental analysis }\end{array}$ & 20 \\
\hline Pilot Feedlot & & & $x$ & $\mathrm{x}$ & & & & & $\begin{array}{l}\text { Identification of products \& by products requiring } \\
\text { environmental analysis }\end{array}$ & 300 \\
\hline Cellulose to Sugar and Ethanol & $\mathrm{x}$ & & & & & & & & $\begin{array}{l}\text { Identification of products \& by products requiring } \\
\text { environmental analysis }\end{array}$ & 40 \\
\hline $\begin{array}{l}\text { Biological Production of organic solvents from cellulosic } \\
\text { wastes }\end{array}$ & $\mathrm{x}$ & & $\mathrm{x}$ & & & & & & $\begin{array}{l}\text { Identification of products \& by products requiring } \\
\text { environmental analysis }\end{array}$ & 50 \\
\hline Fermentation Heat Tolerant Molds to Alcohol & $x$ & & & & & & & & $\begin{array}{l}\text { Identification of products \& by products requiring } \\
\text { environmental analysis }\end{array}$ & 34 \\
\hline Enzyme Hydrolysis - Acetone - Butanol \& Acetic Acid & $x$ & & & & & & & & $\begin{array}{l}\text { Identification of products \& by products requiring } \\
\text { environmental analysis }\end{array}$ & 50 \\
\hline Control Digesters & $\mathrm{x}$ & & $\mathrm{x}$ & $\mathrm{x}$ & & & & & $\begin{array}{l}\text { Identification of products \& by products requiring } \\
\text { environmental analysis }\end{array}$ & 16 \\
\hline Mutants of Trichoderma/Virde & $x$ & & & & & & & & $\begin{array}{l}\text { Identification of products \& by products requiring } \\
\text { environmental analysis }\end{array}$ & 40 \\
\hline Fermentation of Seed Weeds & $x$ & & & & & & & & $\begin{array}{l}\text { Identification of products \& by products requiring } \\
\text { environmental analysis }\end{array}$ & 18 \\
\hline
\end{tabular}


TABLE IV - 28 (Cont)

PROJECTS WITH ENVIRONMENTAL CONTROL ASPECTS

ENERGY TECHNOLOGY: Solar, Geothermal, \& Advanced Energy Systems

PANEL SESSION: Solar Energy

\begin{tabular}{|c|c|c|c|c|c|c|c|c|c|c|}
\hline \multirow[b]{2}{*}{ Project/Element Title } & \multicolumn{8}{|c|}{$\begin{array}{l}\text { Check Primary Category of } \\
\text { Environmental Control Aspects }\end{array}$} & \multirow[b]{2}{*}{$\begin{array}{c}\text { Portion of the Project or Element } \\
\text { Related to Environmental } \\
\text { Control Technology }\end{array}$} & \multirow[b]{2}{*}{$\begin{array}{l}\text { FY } 1977 \text { Funding } \\
\text { Allocation Related } \\
\text { :O Environmental } \\
\text { Control Technology } \\
\text { (\$ in thousands) }\end{array}$} \\
\hline & 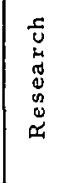 & $\begin{array}{l}0 \\
\stackrel{0}{0} \\
\tilde{D} \\
\tilde{D} \\
\tilde{n}\end{array}$ & 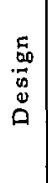 & 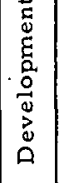 & 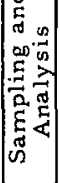 & 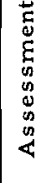 & 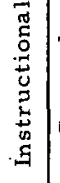 & $\begin{array}{l}3 \\
0 \\
0 \\
0 \\
0 \\
0 \\
0\end{array}$ & & \\
\hline Bench Scale - Experimental Thermochemical Conversion & $\mathrm{x}$ & & $\mathbf{x}$ & $\mathbf{x}$ & & & & & $\begin{array}{l}\text { Identification of products \& by products requiring } \\
\text { environmental analysis }\end{array}$ & 70 \\
\hline Operation of Wood-to-Oil pilot plant & $\mathrm{x}$ & & & $\mathbf{x}$ & & & & & $\begin{array}{l}\text { Identification of products \& by products requiring } \\
\text { environmental analysis }\end{array}$ & 120 \\
\hline Water/Steam Gas & $x$ & & & & & & & & $\begin{array}{l}\text { Identification of products \& by products requiring } \\
\text { environmental analysis }\end{array}$ & 50 \\
\hline Application of SGFM Technology to other feedstocks & $\mathbf{x}$ & & $\mathrm{x}$ & & & & & & $\begin{array}{l}\text { Identification of products \& by products requiring } \\
\text { environmental analysis }\end{array}$ & 50 \\
\hline $\begin{array}{l}\text { Direct Combustion, collection, harvesting, \& conversion } \\
\text { of Biomass }\end{array}$ & $\mathbf{x}$ & & $\mathbf{x}$ & & & & & & $\begin{array}{l}\text { Identification of products \& by products requiring } \\
\text { environmental analysis }\end{array}$ & 150 \\
\hline Conversion of Biomess into Gaseous Products & $\mathrm{x}$ & & $\mathbf{x}$ & & & & & & $\begin{array}{l}\text { Identification of products \& by products requiring } \\
\text { environmental analysis }\end{array}$ & 100 \\
\hline Gasification & $x$ & & & & & & & & $\begin{array}{l}\text { Identification of products \& by products requiring } \\
\text { environmental analysis }\end{array}$ & 150 \\
\hline Catalytic Gasification & $x$ & & & & & & & & $\begin{array}{l}\text { Identification of products \& by products requiring } \\
\text { environmental analysis }\end{array}$ & 50 \\
\hline Georgia Tech Biomass Conversion Study & $x$ & & & & & & & & $\begin{array}{l}\text { Identification of produc } s \text { \& by prcducts requiring } \\
\text { environmental analysis }\end{array}$ & 40 \\
\hline $\begin{array}{l}\text { Systems Study of energy forming concepts based on } \\
\text { sugarcane, sweet sorghum and sugar beets }\end{array}$ & $\mathrm{x}$ & & & & & & & & $\begin{array}{l}\text { Identification of products \& by products requiring } \\
\text { environmental analysis }\end{array}$ & 40 \\
\hline $\begin{array}{l}\text { Cultivation of Filamentous blue-green algae in solar } \\
\text { bioconversion }\end{array}$ & $\mathrm{x}$ & & & & & & & & $\begin{array}{l}\text { Identification of products \& by products requiring } \\
\text { environmental analysis }\end{array}$ & 30 \\
\hline Biological Investigation of kelp as a source of energy & $\mathrm{x}$ & & & & & & & & $\begin{array}{l}\text { Identification of products \& by products requiring } \\
\text { environmental analysis }\end{array}$ & 60 \\
\hline Energy Production from sugar cane \& tropical grasses & $\mathbf{x}$ & & & & & & & & $\begin{array}{l}\text { Identification of products \& by products requiring } \\
\text { environmental analysis }\end{array}$ & 70 \\
\hline
\end{tabular}


TABLE IV-28 (Cont)

PROJECTS WITH ENVIRONMENTAL CONTROL ASPECTS

ENERGY TECHNOLOGY: Solar, Geothermal, \& Advanced Energy Systems

PANEL SESSION: 'Solar Energy

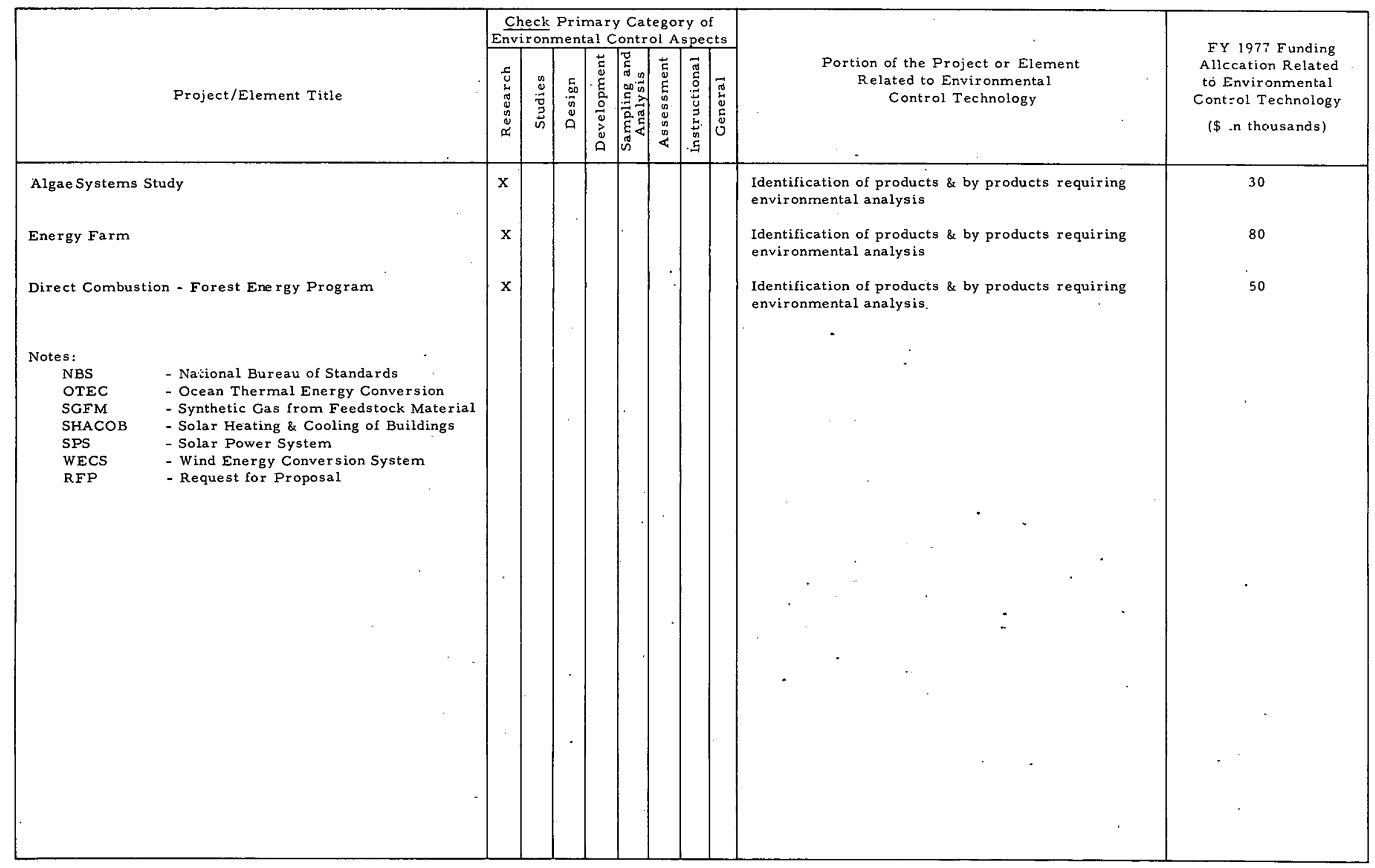




\section{E. Environment and Safety}

The environmental control related projects within the office of the Assistant Administrator for Environment and Safety (AES) were primarily located in the Division of Environmental Control Technology (ECT). They are denoted in Tables IV-29 and IV-30. The total AES FY 1977 funding associated with environmental control activities was $\$ 17,973,000$ of which ECT projects comprised 93 percent, mainly in the areas supporting fossil and nuclear energy development. Fossil energy related activities comprised 33 percent and nuclear energy 45 percent of the total. The remaining 22 percent was divided into multi-technology (15 percent), solar and geothermal ( 5 percent), and conservation ( 2 percent).

In the fossil energy area, the majority of the applicable AES funding was devoted to environmental control activities related to the production of energy from coal. The remainder was primarily related to petroleum and natural gas programs with oil shale and in-situ technology development accounting for the smallest effort because of the limited RD\&D efforts in that area, due to the present state-of-the-art in these energy disciplines.

Solar, geothermal, and conservation activities were a small portion of the total AES funding related to environmental control technology, primarily due to the recent emergence of these energy technologies. Principal emphasis was placed on heat transfer materials development for solar application, on waste disposal and $\mathrm{H}_{2} \mathrm{~S}$ control for geothermal energy related activities, and on urban and industrial waste control and electric power transmission environmental impacts for conservation related efforts.

Nuclear energy related activities were divided into two main areas. The first involved the analysis of nuclear fuel cycles to assess the adequacy of existing environmental controls and the need for additional control requirements. The remainder of the nuclear energy associated activities were in decommissioning and decontamination efforts involved in managing surplus nuclear facilities.

The energy materials transport efforts within ECT are devoted to transportation studies including risk assessments and testing, including testing of shipping casks for radioactive wastes. Additionally, transportation statistics on attack impact, severity of accidents, and relevant environmental transport accidents were kept up to date utilizing the latest computer technology. 
TABLE IV - 29

PROJECTS WITH ENVIRONMENTAL CONTROL ASPECTS

ENERGY TECHNOLOGY: Environment \& Safety

PANEL SESSION: Biomedical \& Environmental Research

\begin{tabular}{|c|c|c|c|c|c|c|c|c|c|c|}
\hline \multirow[b]{2}{*}{ Project/Element Title } & \multicolumn{8}{|c|}{$\begin{array}{l}\text { Check Primary Category of } \\
\text { Environmental Control Aspects }\end{array}$} & \multirow{2}{*}{$\begin{array}{l}\text { Portion of the Project or Element } \\
\text { Related to Environmental } \\
\text { Control Technology }\end{array}$} & \multirow{2}{*}{$\begin{array}{l}\text { FY } 1977 \text { Funding } \\
\text { Allocation Related } \\
\text { to Environmental } \\
\text { Contro: Technology } \\
\text { (\$ in Shousands) }\end{array}$} \\
\hline & 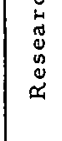 & 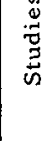 & 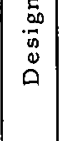 & $\begin{array}{l}\varepsilon \\
0 \\
0 \\
0 \\
0 \\
0 \\
0 \\
0 \\
0\end{array}$ & 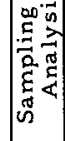 & 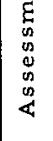 & 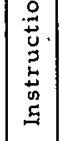 & 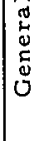 & & \\
\hline Bioengineering Research & $\mathrm{x}$ & & & & & & & & $\begin{array}{l}\text { Bioprocess development for energy production \& } \\
\text { pollution abatement, } 20 \%\end{array}$ & 10 \\
\hline $\begin{array}{l}\text { Ecological Investigation of Uranium Mine \& Mill Tailings } \\
\text { in the Southwest U.S. }\end{array}$ & & & & & & & & $\mathrm{x}$ & $\begin{array}{l}\text { Evaluate revegetation trials, alternative rehabilition } \\
\text { measures, \& recommend rehabilitation protocol, } 60 \%\end{array}$ & 60 \\
\hline Biophysical Chemistry & $\mathrm{x}$ & & & & & & & & $\begin{array}{l}\text { Photosynthesis \& Biomass - solid waste utilization, } \\
50 \%\end{array}$ & 297 \\
\hline Covalent Structure Analysis of Proteins & $\mathrm{x}$ & & & & & & & & Properties of enzymes which detoxify poisons, $50 \%$ & 29 \\
\hline IVEP Geothermal: Water Quality & $\mathrm{x}$ & & & & & & & & $\begin{array}{l}\text { Explore ways that geothermal resources could be } \\
\text { used to improve water quality in Imperial valley, } 20 \%\end{array}$ & 101 \\
\hline $\begin{array}{l}\text { Environmental Effects of Solid Waste as a Supplemental } \\
\text { Fuel }\end{array}$ & $x$ & & & & & & & & 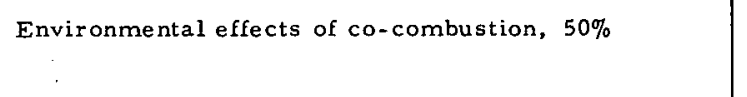 & 68 \\
\hline $\begin{array}{l}\text { Study of Microbiological Air Quality in Relation to the Ames } \\
\text { Municipal Solid Waste Disposal System }\end{array}$ & $\mathrm{x}$ & $\mathrm{x}$ & & & & & & & $\begin{array}{l}\text { Analysis \& suggested solutions for mitigating potential } \\
\text { hazards, } 20 \%\end{array}$ & 14 \\
\hline Assessment \& Control of Radioactive Air Contaminants & $\mathrm{x}$ & & & & $\mathrm{x}$ & $\mathrm{x}$ & & & $\begin{array}{l}\text { Assess, monitor \& control contaminants in public and } \\
\text { occupational environments, } 50 \%\end{array}$ & 42 \\
\hline $\begin{array}{l}\text { Assessment of Environmental Conditions of the Great Lakes } \\
\text { in Relation to Power Production }\end{array}$ & & $\mathrm{x}$ & & & & & & & $\begin{array}{l}\text { Evaluate control technology \& resource management } \\
\text { option for mitigating adverse impacts, } 25 \%\end{array}$ & 35 \\
\hline Assessment \& Control of non-nuclear Air Contaminants & $\mathrm{x}$ & & & & & & & & $\begin{array}{l}\text { Basic elements of control technology are evaluated for } \\
\text { effectiveness, deficiencies a re remedied by improving } \\
\text { existing methods, or devising alternatives, } 50 \%\end{array}$ & 58 \\
\hline $\begin{array}{l}\text { Biomedical Treatment of Waste Streams from Conversion } \\
\text { Processes }\end{array}$ & $\mathbf{x}$ & & & & & & & & $\begin{array}{l}\text { Research \& development of proposed schemes for } \\
\text { bioreactor systems, } 100 \%\end{array}$ & 75 \\
\hline Terrestrial Effects of Oil Shale Development & $\mathrm{x}$ & & & & & & & & $\begin{array}{l}\text { Minimize environmental impact \& set standards of } \\
\text { performance for pollution control equipment, } 100 \%\end{array}$ & 207 \\
\hline
\end{tabular}


TABLE IV-29 (Cont)

PROJECTS WITH ENVIRONMENTAL CONTROL ASPECTS

ENERGY TECHNOLOGY: Environment \& Safety

PANEL SESSION: Biomedical \& Environmental Research

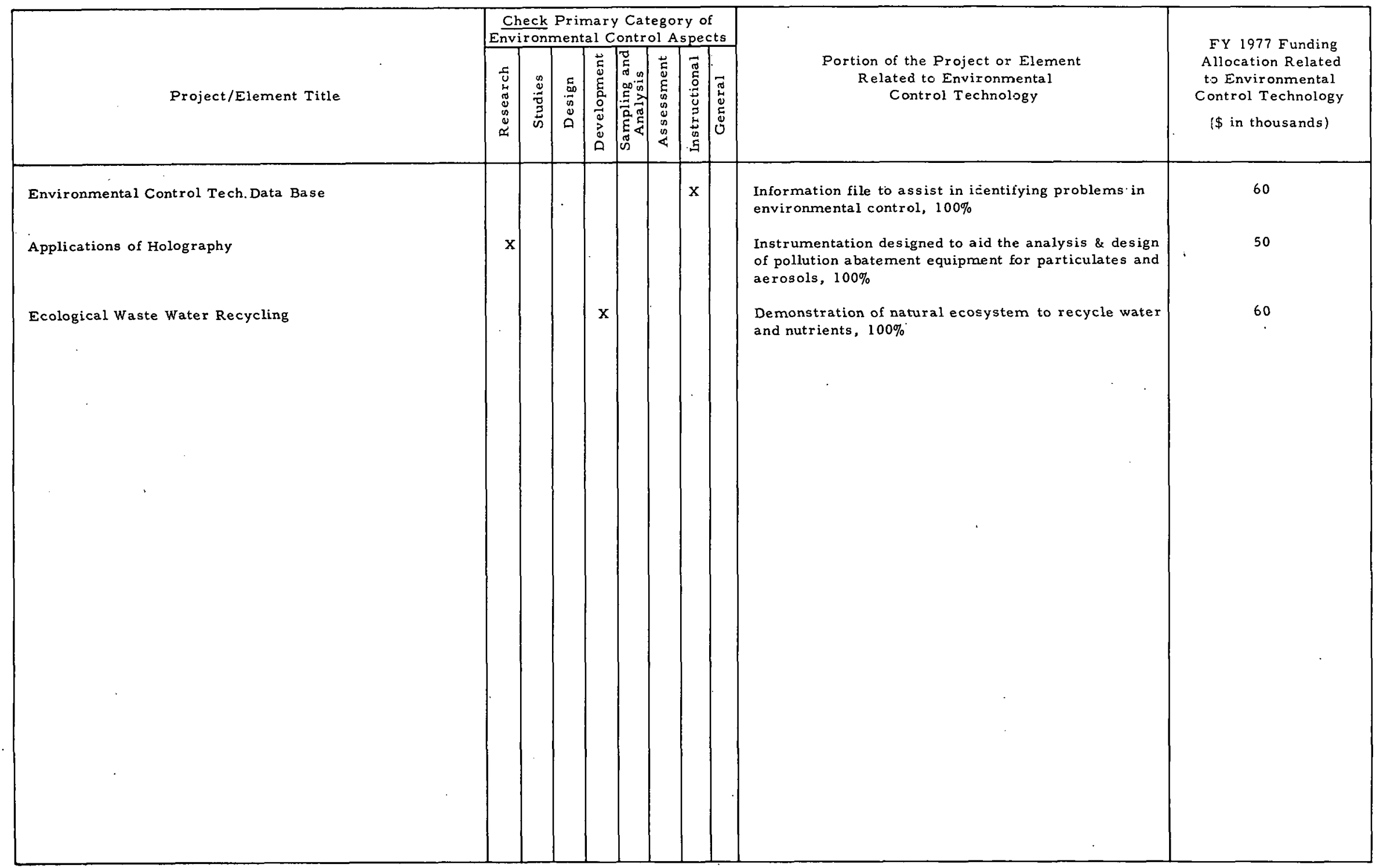


TABLE IV -30

PROJECTS WITH ENVIRONMENTAL CONTROL ASPECTS

ENERGY TECHNOLOGY: Environment and Safety

PANEL SESSION: Environment Control Technology

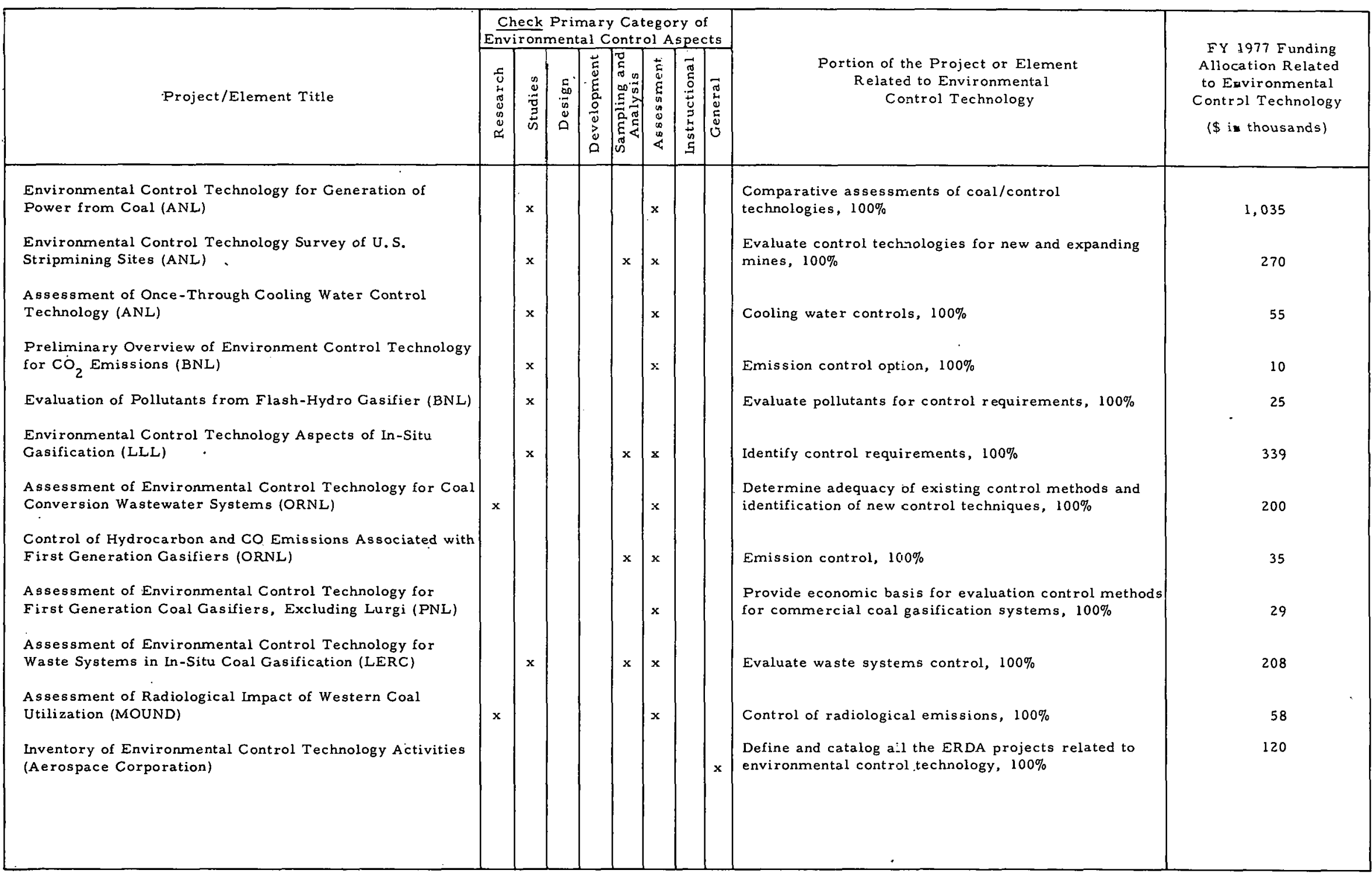


TABLE IV - 30 (Cont)

PROJECTS WITH ENVIRONMENTAL CONTROL ASPECTS

ENERGY TECHNOLOGY: Environment and Safety

PANEL SESSION: Environment Control Technology.

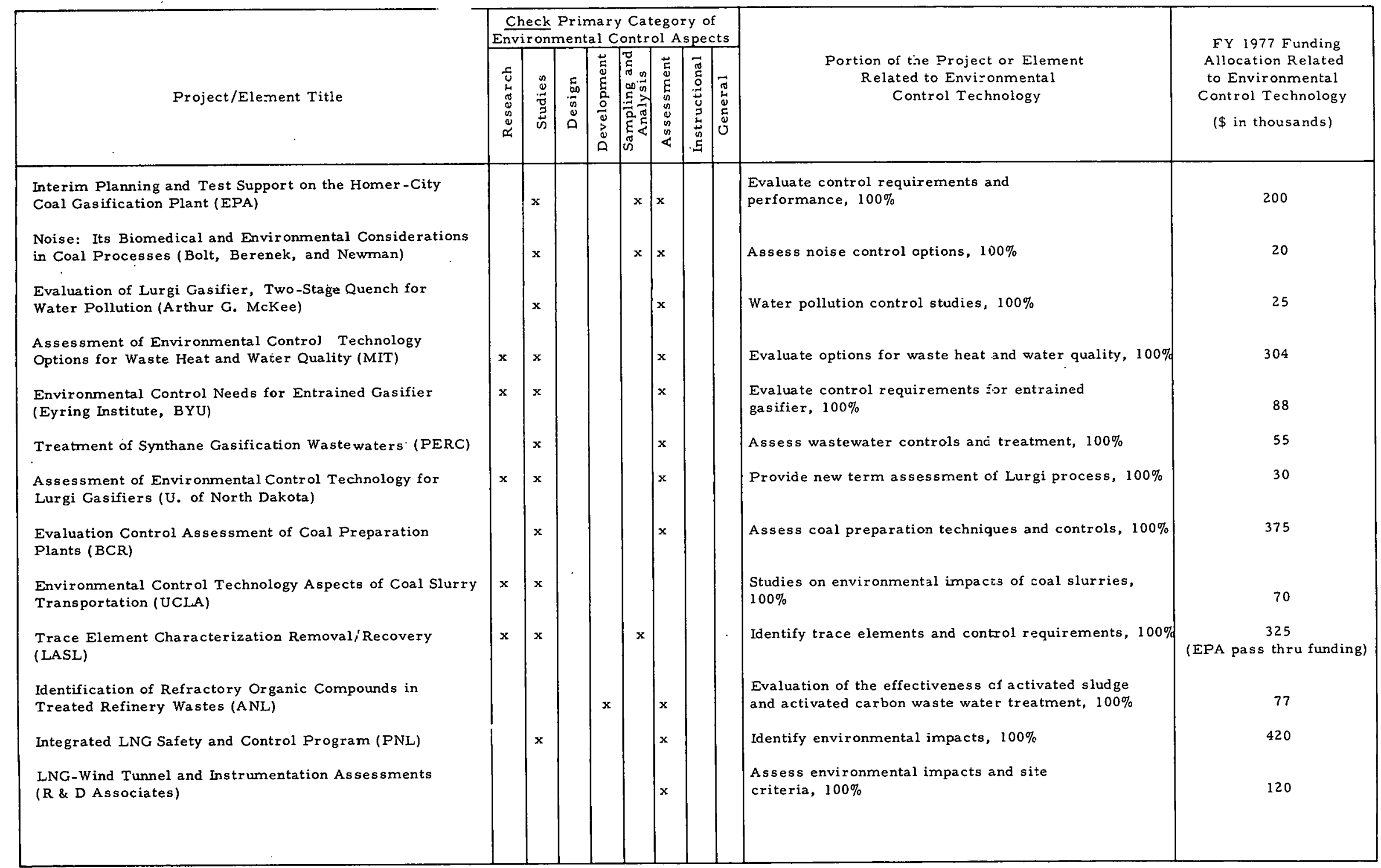


TABLE IV - 30 (Cont)

PROJECTS WITH ENVIRONMENTAL CONTROL ASPECTS

ENERGY TECHNOLOGY: Environment and Safety

PANEL SESSION: Environment Control Technology

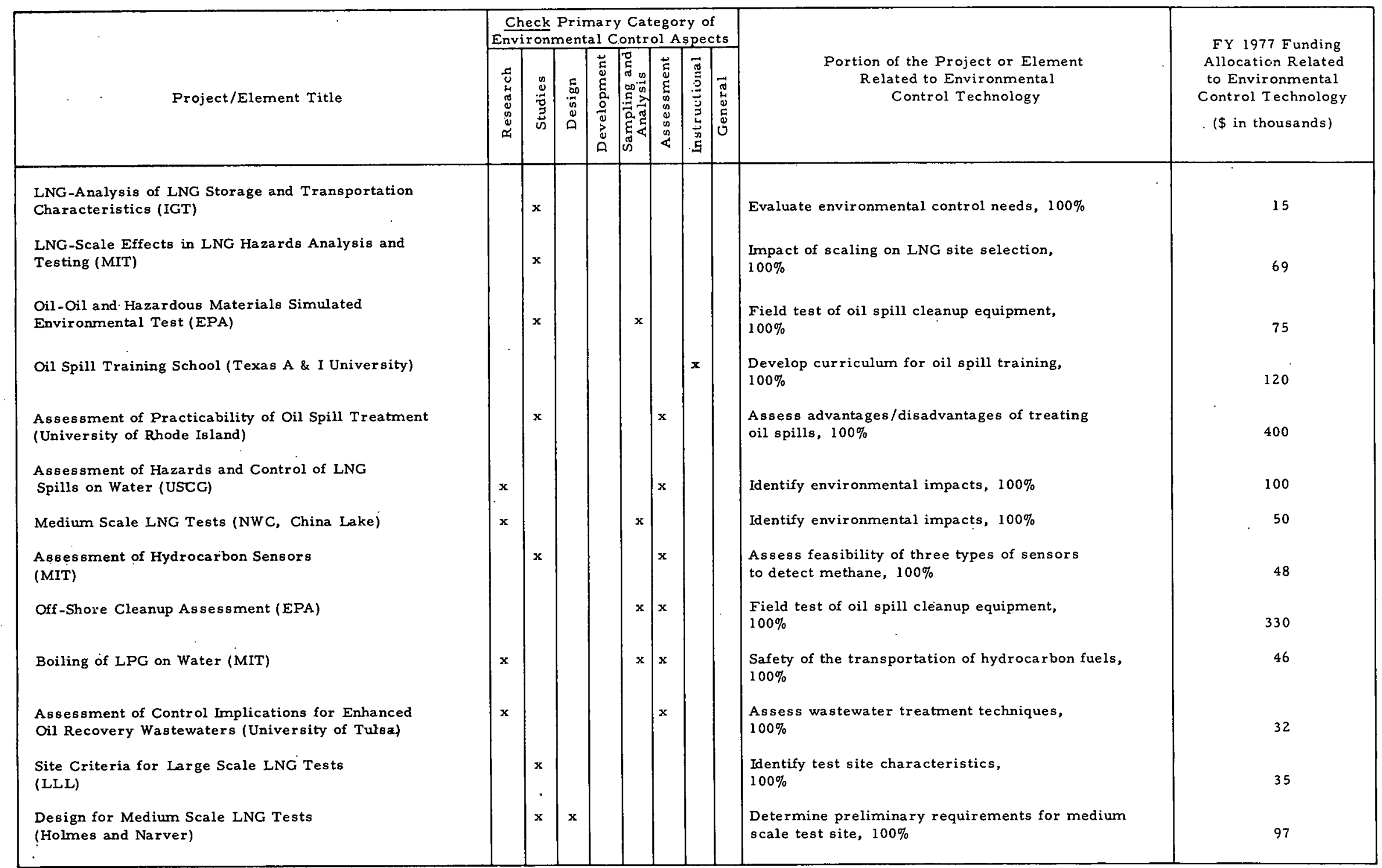


TABLE IV - 30 (Cont)

PROJECTS WITH ENVIRONMENTAL CONTROL ASPECTS

ENERGY TECHNOLOGY: Environment and Safety

PANEL SESSION: Environment Control Technology

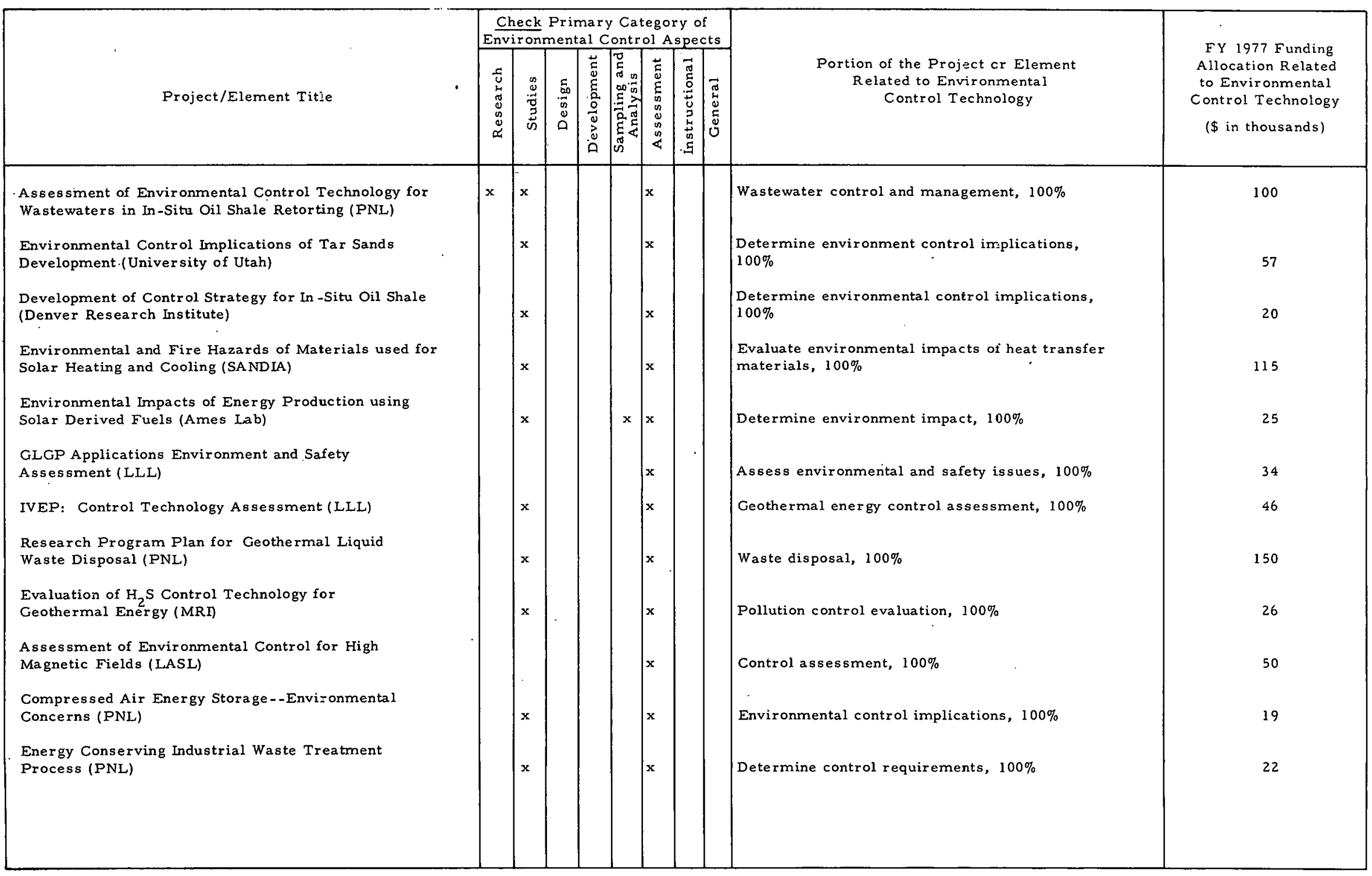


TABLE IV - 30 (Cont)

PROJECTS WITH ENVIRONMENTAL CONTROL ASPECTS

ENERGY TECHNOLOGY: Environment and Safety

PANEL SESSION: Environment Control Technology

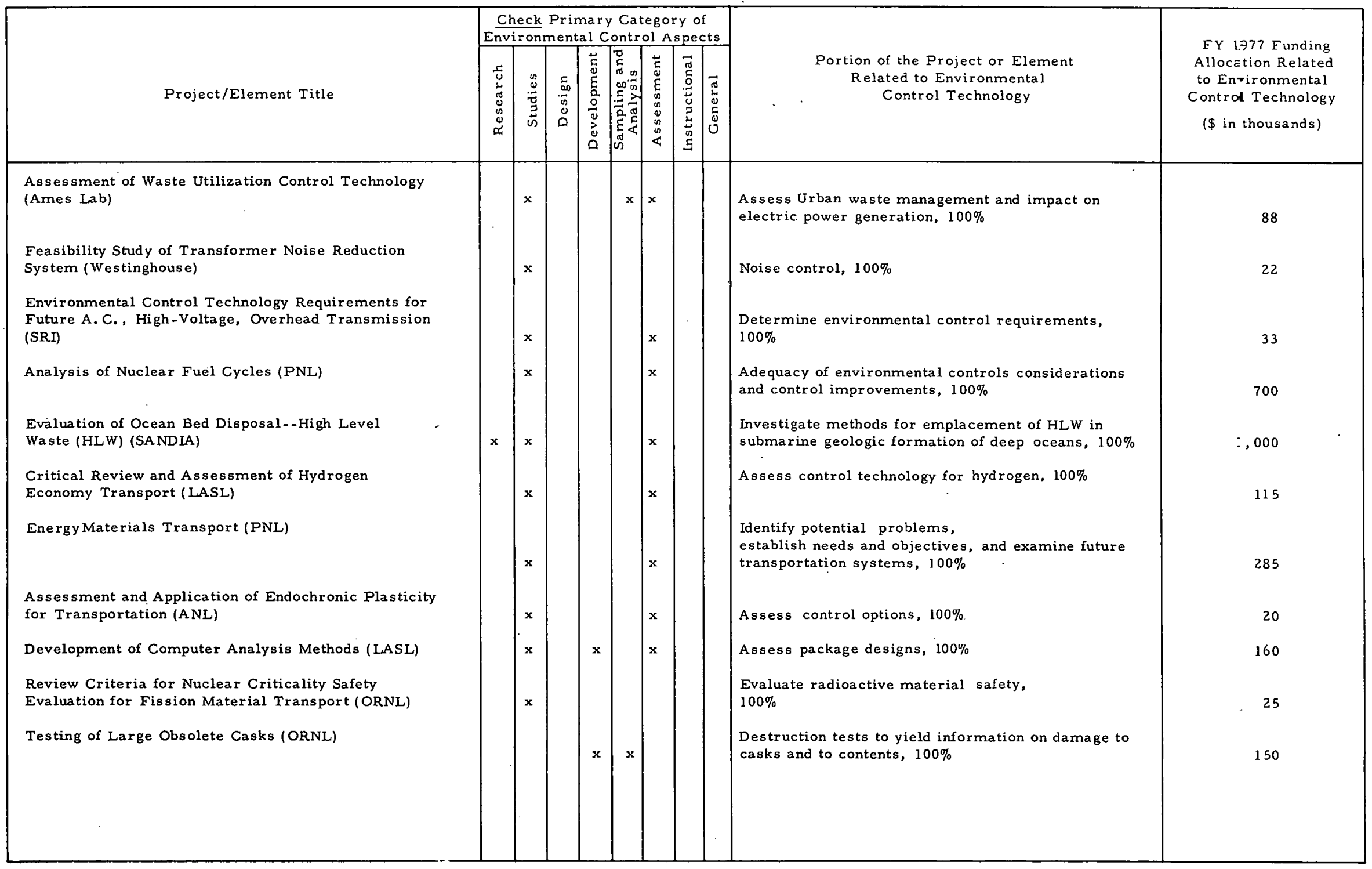


TABLE IV - 30 (Cont)

PROJECTS WITH ENVIRONMENTAL CONTROL ASPECTS

ENERGY TECHNOLOGY : Environment and Safety

PANEL SESSION: Environment Control Technology

\begin{tabular}{|c|c|c|c|c|c|c|c|c|c|c|}
\hline \multirow[b]{2}{*}{ Project/Element T:tle } & \multicolumn{8}{|c|}{$\begin{array}{l}\text { Check Primary Category of } \\
\text { Environmental Control Aspects }\end{array}$} & \multirow[b]{2}{*}{$\begin{array}{c}\text { Portion of the Project or Element } \\
\text { Related to Envircnmental } \\
\text { Control Technology }\end{array}$} & \multirow[b]{2}{*}{$\begin{array}{l}\text { FY } 1977 \text { Funding } \\
\text { Allocation Related } \\
\text { to Environmental } \\
\text { Control Technology } \\
\text { ( } \$ \text { in thousands) }\end{array}$} \\
\hline & 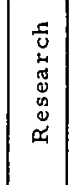 & 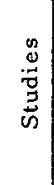 & $\begin{array}{c}5 \\
0 \\
5 \\
0 \\
0 \\
0\end{array}$ & 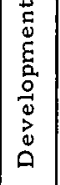 & 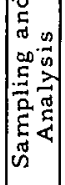 & 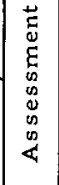 & 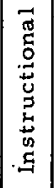 & 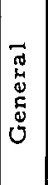 & & \\
\hline Transportation Safety Studies (PNL) & & $\mathbf{x}$ & & $\mathbf{x}$ & $\mathbf{x}$ & $x$ & & & $\begin{array}{l}\text { Develop methodology and perform } \\
\text { risk assessments, } 100 \%\end{array}$ & 240 \\
\hline Package Faikure from Malevolent Attack (SANDIA) & & $\mathbf{x}$ & & & $\mathbf{x}$ & $\mathbf{x}$ & & & $\begin{array}{l}\text { Determine attack impact and improvement } \\
\text { measures, } 100 \%\end{array}$ & 60 \\
\hline $\begin{array}{l}\text { Study of Physical Parameters of Transportation } \\
\text { Accidents (SANDIA) }\end{array}$ & & $\mathbf{x}$ & & & & & & & Qualify severity of accidents, $100 \%$ & 85 \\
\hline Full-Scale Vehicle Testing Program (SANDIA) & $\mathbf{x}$ & & & $\mathrm{x}$ & $\mathbf{x}$ & $\mathbf{x}$ & & & $\begin{array}{l}\text { Assess validity of analyses and scale model } \\
\text { testing, } 100 \%\end{array}$ & 830 \\
\hline $\begin{array}{l}\text { Structural Response of Shipping Containers Under } \\
\text { Accident Conditions (BATTELLE) }\end{array}$ & & $\mathrm{x}$ & & $\mathbf{x}$ & & & & & $\begin{array}{l}\text { Determine structural integrity and dynamic material } \\
\text { properties of waste containers, } 100 \%\end{array}$ & 100 \\
\hline Transportation Statistics Data Bank (ORNL) & & $\mathbf{x}$ & & & & & & & $\begin{array}{l}\text { Maintain data bank on ERDA } \\
\text { statistics, } 100 \%\end{array}$ & 50 \\
\hline $\begin{array}{l}\text { Maintenance of Transportation Accident Environmental } \\
\text { Data Bank (SA NDIA) }\end{array}$ & & $\mathbf{x}$ & & & & & & & $\begin{array}{l}\text { Storage of relevant environmental } \\
\text { accident data, } 100 \%\end{array}$ & 60 \\
\hline $\begin{array}{l}\text { Films - Transport and Packaging of Radioactive } \\
\text { Waste (SANDIA) }\end{array}$ & & & & & & & $\mathbf{x}$ & & $\begin{array}{l}\text { Production of films or: packaging and shipping of } \\
\text { radioactive waste, } 100 \%\end{array}$ & 50 \\
\hline $\begin{array}{l}\text { Exhibit (Operating)-Transporting Radioactive Cargoes } \\
\text { (Oak Ridge Associated Universities) }\end{array}$ & & & & & & & $\mathbf{x}$ & & $\begin{array}{l}\text { Increase public awareness of environmental control } \\
\text { requirements, } 100 \%\end{array}$ & 45 \\
\hline Transport Exhibit Operations (NORCUS) & & & & & & & $\mathrm{x}$ & & $\begin{array}{l}\text { Increase public awareness of environmental control } \\
\text { requirements, } 100 \%\end{array}$ & 34 \\
\hline Transport Consultant & & & & & & & & $\mathbf{x}$ & Independent law analyses, $100 \%$ & 21 \\
\hline Surplus Facility Surveillance (ANL) & & & & & $\mathbf{x}$ & & & & Monitor radiation hazards, $100 \%$ & 20 \\
\hline Salvage of Alpha Contaminated Metals (ANL) & $\mathrm{x}$ & $\mathbf{x}$ & & & & & & & $\begin{array}{l}\text { To provide and evaluate techniques for } \\
\text { decontamination of metals, } 100 \%\end{array}$ & 75 \\
\hline
\end{tabular}


TABLE IV -30 (Cont)

PROJECTS WITH ENVIRONMENTAL CONTROL ASPECTS

ENERG TECHNOLOGY: Environment and Safety

PANEL SESSION: Environment Control Technology

\begin{tabular}{|c|c|c|c|c|c|c|c|c|c|c|}
\hline \multirow[b]{2}{*}{ Project/Element Title } & \multicolumn{8}{|c|}{$\begin{array}{l}\text { Check Primary Category of } \\
\text { Environmental Control Aspects }\end{array}$} & \multirow[b]{2}{*}{$\begin{array}{l}\text { Portion of the Project or Element } \\
\text { Related to Environmental } \\
\text { Control Technology }\end{array}$} & \multirow[b]{2}{*}{$\begin{array}{l}\text { FY } 1977 \text { Funding } \\
\text { Allocation Related } \\
\text { to Environmental } \\
\text { Control Technology } \\
\text { (\$ is thousands) }\end{array}$} \\
\hline & 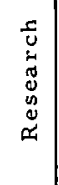 & 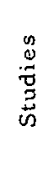 & 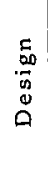 & 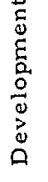 & 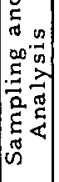 & 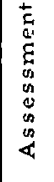 & 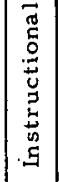 & $\begin{array}{l}\vec{T} \\
\tilde{U} \\
\tilde{D} \\
\tilde{D} \\
\tilde{U}\end{array}$ & & \\
\hline Surplus Facility Surveillance (ORNL) & & & & & $\mathbf{x}$ & & & & Monitor radiation hazards, $100 \%$ & 105 \\
\hline FPDL Facility Surveillance (ORNL) & & & & & $\mathbf{x}$ & & & & Monitor radiation hazards, $100 \%$ & 160 \\
\hline $\begin{array}{l}\text { Planning for Disposition of Excess Reactor } \\
\text { Facilities (ORNL) }\end{array}$ & & $\mathbf{x}$ & & & & & & & $\begin{array}{l}\text { Study alternatives for making reactors } \\
\text { indefinitely, environmentally safe, } 100 \%\end{array}$ & 70 \\
\hline Disposition of Hanford Retired Facility (PNL) & & $\mathbf{x}$ & & $\mathbf{x}$ & $\mathbf{x}$ & $\mathrm{x}$ & & & $\begin{array}{l}\text { Planning for Hanford } D \& D(80 \%) \text { and development } \\
\text { of } D \& D \text { techniques }(20 \%)\end{array}$ & 640 \\
\hline $\begin{array}{l}\text { Geologic, Geophysical, and Biologic Characterization } \\
\text { of Solid Waste Burial Grounds (PNL) }\end{array}$ & $\mathbf{x}$ & & & & $\mathbf{x}$ & $\mathbf{x}$ & & & $\begin{array}{l}\text { Define the hazards of buried radionucleides to the } \\
\text { environment, } 100 \%\end{array}$ & 228 \\
\hline Hallam and Piqua Surveillance.(BATTELLE) & & & & & $\mathbf{x}$ & & & & Radiation monitoring, $100 \%$ & 2 \\
\hline Surveillance-INEL Shutdown Reactors (Aerojet Nuclear) & & & & & $\mathbf{x}$ & & & & Radiation monitoring, $100 \%$ & 60 \\
\hline Surplus Facility Surveillance (Atlantic Richfield) & & & & & $\mathbf{x}$ & & & & Radiation monitoring, $100 \%$ & 350 \\
\hline $\begin{array}{l}\text { Contaminated Equipment Volume Reduction } \\
\text { (Atlantic Richfield) }\end{array}$ & $\mathbf{x}$ & & $\mathbf{x}$ & $\mathbf{x}$ & & & & & $\begin{array}{l}\text { Reduction of volume of contaminated equipment to } \\
\text { a size and form suitable for terminal storage of } \\
\text { disposal, } 100 \%\end{array}$ & 310 \\
\hline$D \& D$ of SNAP Facility (Atomics International) & & & & & $\mathbf{x}$ & $\mathrm{x}$ & & $\mathbf{x}$ & Removal of a potential environmental hazard, $100 \%$ & 130 \\
\hline D \& D of SRE Facility (Atomics International) & & $\mathbf{x}$ & & & $\mathbf{x}$ & $x$ & & $\mathbf{x}$ & Removal of a potential environmental hazard, $100 \%$ & 2,600 \\
\hline Surplus Facility Surveillance-HWCTR Stand-by (Du Pont) & & & & & $\mathbf{x}$ & & & & Radiation monitoring, $100 \%$ & 5 \\
\hline Disposal of Contaminated Metal (NLO) & & & $\mathbf{x}$ & $\mathbf{x}$ & & $\mathbf{x}$ & & & $\begin{array}{l}\text { Design and construct a portable ferrous smelter } \\
\text { for recycling contaminated scrap, } 100 \%\end{array}$ & 200 \\
\hline D \& D of PRNC Reactor Facility (PRNC) & & $\mathbf{x}$ & & & & & & & $\begin{array}{l}\text { Prepare decontamination plan for } C E E R \text { reactor } \\
\text { facility; Mayaquez, Puerto Rico, } 100 \%\end{array}$ & 50 \\
\hline Project GNOME Site Disposal (REECO) & & & & & $\mathbf{x}$ & $\mathbf{x}$ & & $\mathbf{x}$ & Removal of a potential environmental hazard, $100 \%$ & 100 \\
\hline
\end{tabular}


TABBLE IV-30 (Cont)

PROJECTS WITH ENVIRONMENTAL CONTROL ASPECTS

ENERGY TECHNOLOGY: Environment and Safety

PANEL SESSION: Environmental Control Technology

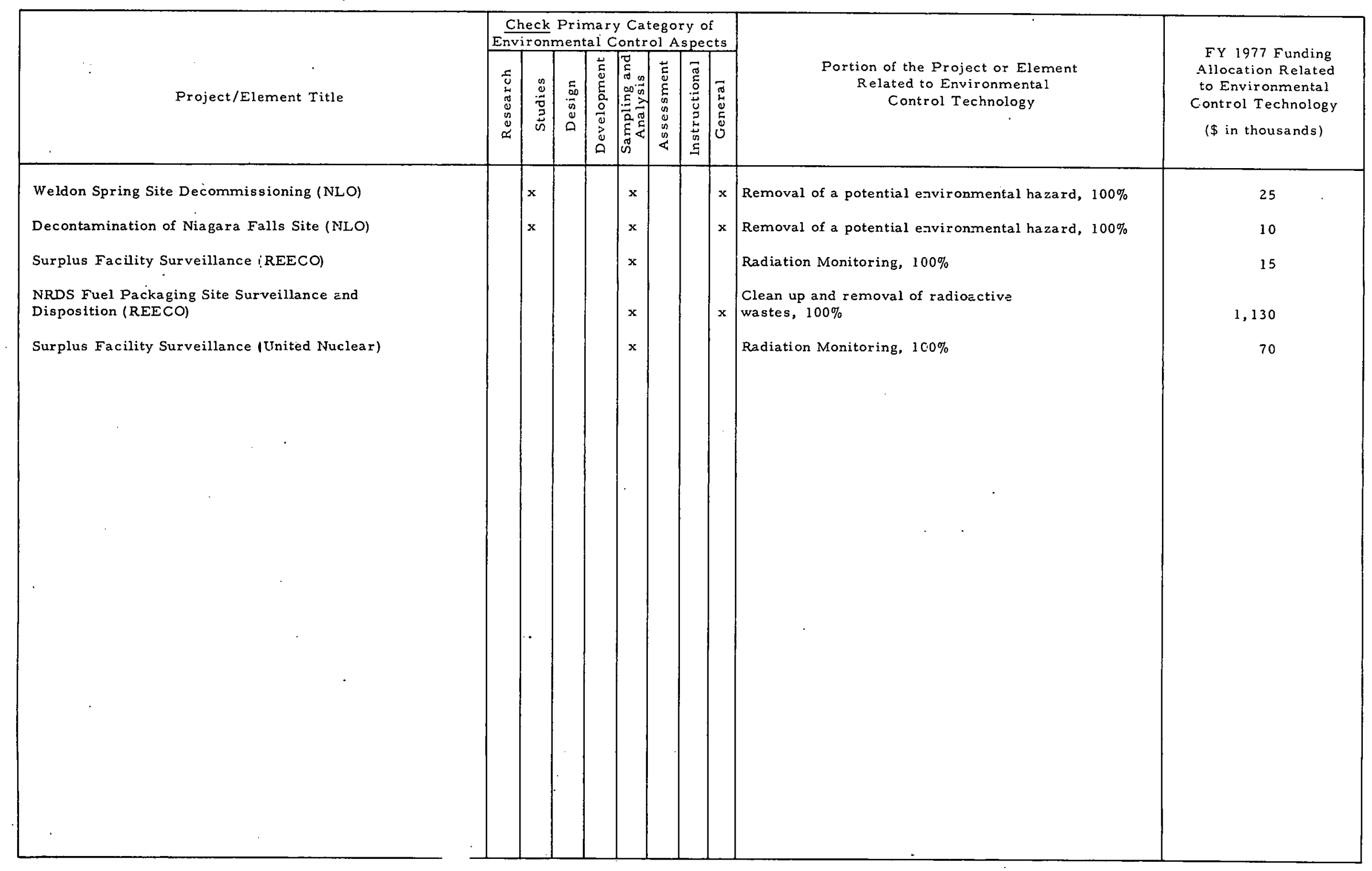


V. Bibliography

1. Federal Wind Energy Program; Summary Report, ERDA 77-32, ERDA/ASGA Division of Solar Energy (January 1977).

2. Fossil Energy Research Program of the Energy Research and Development Administration - FY 1977, ERDA 76-63, ERDA/AFE Office of Program Planning and Analysis (April 1976).

3. Fuels from Biomass Program: Program and Project Status, ERDA 76-137, ERDA/ASGA Division of Solar Energy (November 1976).

4. Geothermal Project Summaries, ERDA 76-53/1, ERDA/ASGA Division of Geothermal Energy (September 1976).

5. Inventory of Federal Energy-Related Environment and Safety Research for FY 1976, ERDA 77-50, ERDA/AES Division of Biomedical and Environmental Research (April 1977).

6. Materials Sciences Programs - FY 1976, ERDA 76-123, ERDA/ASGA Division of Physical Research (September 1976).

7. National Program Plan for Research and Development in Solar Heating and Cooling, ERDA 76-144, ERDA/ASGA Division of Solar Energy (November 1976).

8. National Program Plan for Solar Heating and Cooling of Buildings, Project Summaries, ERDA 76-145, ERDA/ASGA Division of Solar Energy (November 1976).

9. Ocean Thermal Energy Conversion (OTEC). Program Summary, ERDA 76138, ERDA/ASGA Division of Solar Energy (October 1976).

10. Photovoltaic Conversion Program: Summary Report, ERDA 76-161, ERDATASGA Division of Solar Energy (November 1976).

11. Preliminary Environmental Review of the Energy Conservation Research, Development, and Demonstration Programs, ERDA 76-36, ERDA Office of the Assistant Administrator for Conservation (May 1976).

12. Research Contracts in the Physical Sciences, ERDA 76-164, ERDA/ASGA Division of Physical Research (October 1976).

13. Solar Energy Environmental and Resource Assessment Program Summary Report, ERDA 76-138, ERDA/ASGA Division of Solar Energy (October 1976).

14. Solar Energy Program Anthology, ERDA 77-31, ERDA/ASGA Division of Solar Energy (January 1977).

15. Solar Thermal Energy Conversion: Program Summary, ERDA 76-159, ERDA/ASGA Division of Solar Energy (October 1976).

16. Summary Outline of ERDA Geosciences and Geoscience - Related Research, ERDA 76-114, ERDA/ASGA Division of Physical Research (August 1976). 
VI. Glossary

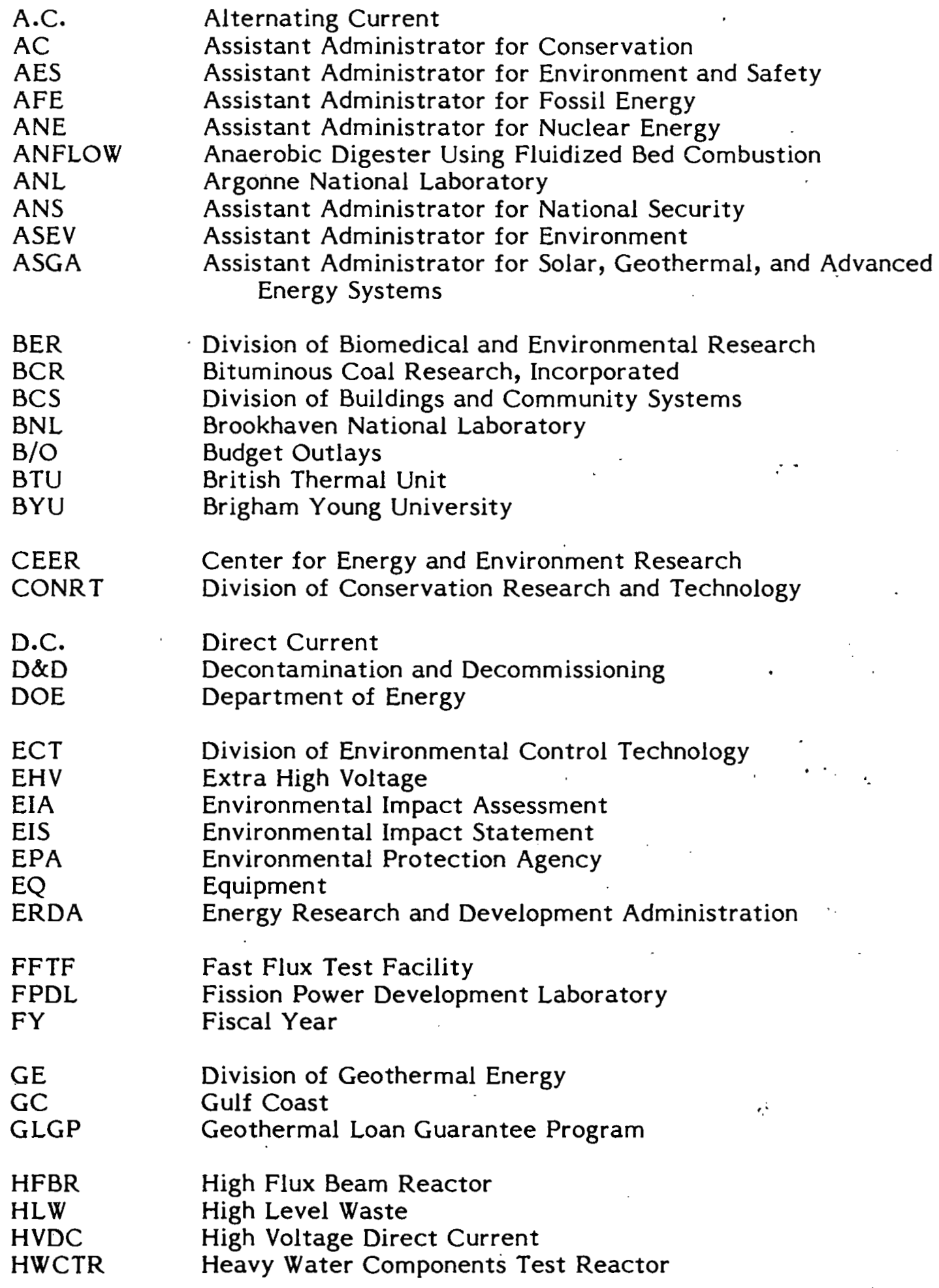




\begin{tabular}{|c|c|}
\hline IGT & Institute of Gas Technology \\
\hline ILW & Intermediate Level Waste \\
\hline INEL & Idaho National Engineering Laboratory \\
\hline INDUS & Division of Industrial Energy Conservation \\
\hline IVEP & Imperial Valley Environmental Project : \\
\hline LASL & Los Alamos Scientific (National) Laboratory \\
\hline LBL & Lawrence Berkeley (National) Laboratory \\
\hline LERC & Laramie Energy Research Center \\
\hline LLL & Lawrence Livermore (National) Laboratory \\
\hline LMFBR & Liquid Metal Fast Breeder Reactor \\
\hline LNG & Liquified Natural Gas \\
\hline LPG & Liquified Petroleum Gas \\
\hline LWR & Light Water Reactor \\
\hline MFE & Division of Magnetic Fusion Energy \\
\hline MIT & Massachusetts Institute of Technology \\
\hline NBS & National Bureau of Standards \\
\hline NCRR & National Center for Resource Reserve \\
\hline NEC & Nuclear Energy Center \\
\hline NEPA & National Environmental Policy Act \\
\hline NLO & National Lead Company of Ohio \\
\hline NOAA & National Oceanic and Atmospheric Administration \\
\hline NR & Division of Naval Reactors \\
\hline NRA & Division of Nuclear Research and Applications \\
\hline NRC & Nuclear Regulatory Commission \\
\hline NRDS & Nuclear Rocket Development Station \\
\hline NWC & Naval Weapons Center, China Lake \\
\hline NWTS & National Waste Terminal Storage Program \\
\hline OC & Office of the Controller \\
\hline OP & Operating Expenses \\
\hline ORNL & Oak Ridge National Laboratory \\
\hline OTEC & Ocean Thermal Energy Conversion \\
\hline PACE & Plant and Capital Equipment \\
\hline PAD & Program Approval Document \\
\hline PCB & Polychlorinated Biphenyls \\
\hline PEP & Positron-Electron Project \\
\hline PERC & Pittsburgh Energy Research Center \\
\hline PNL & Pacific Northwest Laboratory \\
\hline PRNC & Puerto Rico Nuclear Center \\
\hline $\mathbf{R}$ & Division of Physical Research \\
\hline REECO & Reynolds Electric and Engineering Company \\
\hline RDD & Division of Reactor Development and Demonstration \\
\hline $\mathrm{R} \& \mathrm{D}$ & Research and Development \\
\hline $\mathrm{RD} \& \mathrm{D}$ & Research, Development and Demonstration \\
\hline RFP & Request for Proposal \\
\hline RPIS & Research Project Identification System \\
\hline
\end{tabular}


SGFM

SHABOC

SLAC

SNAP

SOLAR

SPS

SRC

SRE

SRI

STOR

TEC

TRU

UCLA

URE

USCG

VHTR

WECS

WPR
Synthetic Gas from Feedstock Material

Solar Heating and Cooling of Buildings

Stanford Linear Accelerator Center

Space Nuclear Auxiliary Power

Division of Solar Energy

Solar Power System

Solvent Refined Coal

Sodium Reactor Experiment

Stanford Research Institute

Division of Energy Storage Systems

Division of Transportation Energy Conservation

Transuranic Waste

University of California at Los Angeles

Division of Uranium Resources and Enrichment

United States Coast Guard

Very High Temperature Gas Cooled Reactor

Wind Energy Conversion System

Division of Waste Management, Production and Reprocessing 
